GRAZIELE LAUTENSCHLAEGER

\title{
ARTE PROGRAMMATA: ENTRE ACIDENTE E CONTROLE
}

Dissertação apresentada à Escola de Engenharia de São Carlos da Universidade de São Paulo para a obtenção do título de mestre em Arquitetura e Urbanismo

Área de Concentração: Teoria e História da Arquitetura e do Urbanismo

Orientadora: Profa. Dra. Anja Pratschke 
Autorizo a reprodução e divulgação total ou parcial deste trabalho, por qualquer meio convencional ou eletrônico, para fins de estudo e pesquisa, desde que citada a fonte.

Ficha catalográfica preparada pela Seção de Tratamento da Informação do Serviço de Biblioteca - EESC/USP

L389a

\section{Lautenschlaeger, Graziele}

Arte programmata : entre acidente e controle / Graziele Lautenschlaeger ; orientadora Anja Pratschke. -São Carlos, 2009 .

Dissertação (Mestrado-Programa de Pós-Graduação em Arquitetura e Urbanismo e Área de Concentração em Teoria e História da Arquitetura e do Urbanismo) -- Escola de Engenharia de São Carlos, 2009.

1. Arte eletrônica. 2. Arte contemporânea.

3. Cibernética de segunda ordem. 4. Processo de design. 5. Acidente e controle. 6. Cultura digital. I. Título. 
FOLHA DE JULGAMENTO

Candidato(a): Bacharel GRAZIELE LAUTENSCHLAEGER.

Dissertação defendida e julgada em 29/03/2010 perante a Comissão Julgadora:

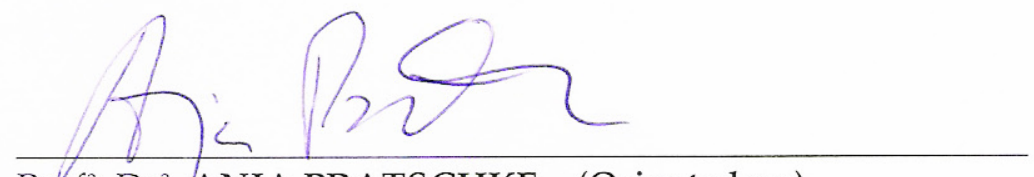

Prof ${ }^{a}$. Dr ${ }^{\mathrm{a}}$. ANJA PRATSCHKE - (Orientadora)

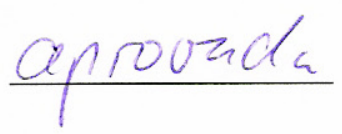

(Escola de Engenharia de São Carlos/USP)

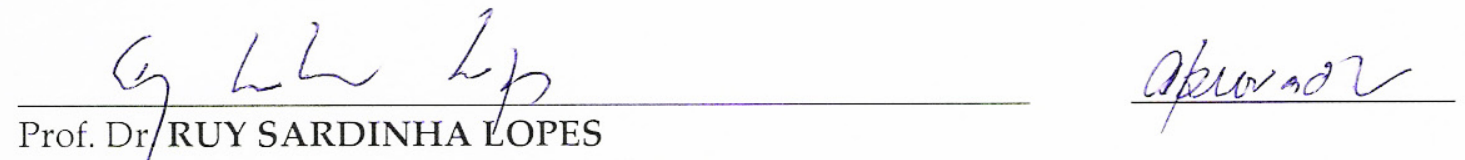

(Escola de Engenharia de São Carlos/USP)

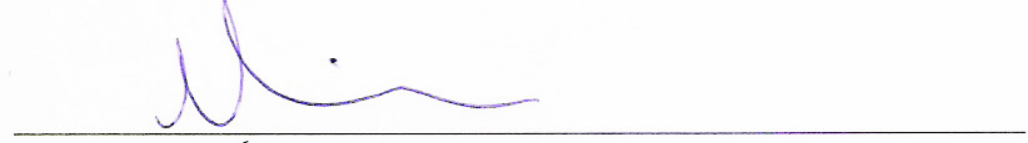

Prof. Dr. JOSÉ DOS SANTOS CABRAL FILHO

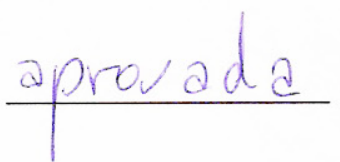

(Universidade Federal de Minas Gerais/UFMG)

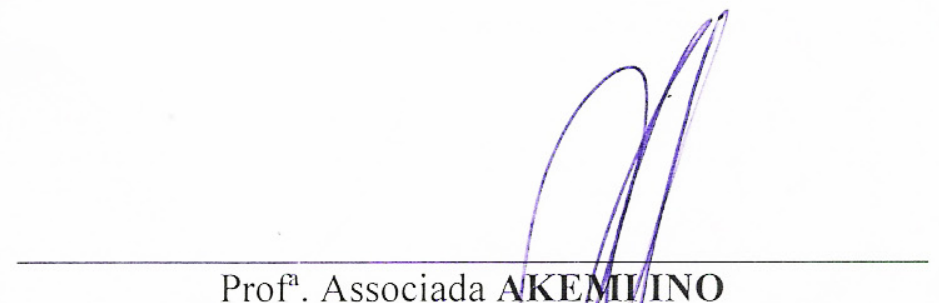

Vice - Coordenadora do Programa de Pós-Graduação em

Arquitetura e Urbanismo, em exercício

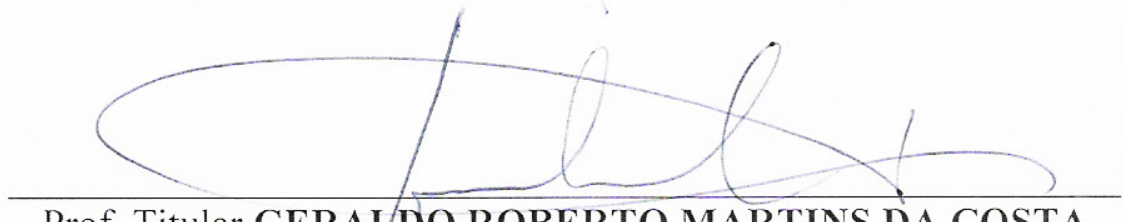

Prof. Titular GERALDO ROBERTO MARTINS DA COSTA

Presidente da Comissão da Pós-Graduação da EESC 

Às pessoas,

aos bichos,

momentos

e lugares

que eu amo. 



\section{AGRADECIMENTOS}

Agradeço à Fundação de Amparo à Pesquisa do Estado de São Paulo (Fapesp) pelo apoio e financiamento concedido a esta pesquisa, proporcionando a abertura de muitas portas ao longo de nosso processo de investigação.

À Anja Pratschke por me aceitar nessa empreitada e por todas as horas que ela dedicou em ler, reler, comentar, criticar, dar ânimo e coragem para que esse trabalho fosse concluído.

Ào Marcelo Tramontano pela orientação fugaz porém memorável.

À Christa Sommerer e Laurent Mignonneau e aos tantos outros amigos do Interface Culture Department da Kunstuniversität Linz, pela solicitude em me ensinar e colaborar com o aprimoramento das ideias.

Aos entrevistados: Monika Fleischmann e Wolfgang Strauss, Peter Matussek, Dietmar Offenhuber, Stephen Kovats, Christa Sommerer e Laurent Mignonneau, Dolo Piqueras e M. José Martinez de Pison, Hide Ogawa, Mika Satomi, Maurice Benayoun, Tiago Martins, Brian Kane, Manuela Pfaffenberger, Andreas Weixler, Sebastian Neitsch, Ivani Santana, Peter Matussek, Pascal Maresch, Katja Kwastek, Tânia Fraga, Michel van Dartel, Yves Bernard, Mauro Arrighi, Ricardo Nascimento, Britta Fehrmann, Barbara U. Schmidt

Aos integrantes do Nomads.usp pela constante interlocução e eventuais favores impagáveis. Em especial à Cynthia Nojimoto, Elza Luli Miyasaka, Gabriela Carneiro e Fábio Abreu Queiroz.

Aos meus amigos, por todas as ajudas concedidas, pelos ouvidos, ombros e lares emprestados, em especial à Luciana Miyoko Massukado, Mário Righetti, Marcos Nagata, Giovanny Gerolla, Daniela Schmidt, Bruno Nagumo e Marcos Paulo Calegari.

À querida Naná, pelo carinho, amor e paciência que ela dedicou diariamente.

Aos meus irmãos Fabiano, Gustavo e Juliana, pelo apoio e pelo respeito à diferença que cada um deles, à sua maneira, sabe dedicar.

Aos meus pais, Nelda e Vagner pelo amor incondicional que eles dedicam, pelo conforto emocional que proporcionam e por sempre me encorajarem a enfrentar universos desconhecidos. 



\section{GUIA DE LEITURA}

Inspirados pela diagramação do livro "The New Media Reader", selecionamos alguns assuntos de relevância que são recorrentes e se complementam nos três capítulos, inter-relacionando-os ao longo do texto através de indicações da página em que são mencionados outras vezes.

Dessa forma criamos uma "nuvem semântica" composta por "hiperlinks", na tentativa de proporcionar uma leitura minimamente recursiva e não-linear, caso haja interesse do leitor.

Para isso, optamos por uma diagramação baseada em cores correspondentes e nos ambientes de programação de arquitetura dataflow, como nos software Max/Msp/litter, Pure Data, VVVV, entre outros. 

Mesmo a abstração tem seu lado penoso (...). Minha secretária chorava, lendo o decreto pelo qual eu tinha sido dispensado. Para me consolar resolvi abstrair suas lágrimas, e durante certo tempo me deleitei com essas diminutas fontes cristalinas que nasciam no ar e se esborrachavam nas pastas, no mata-borrão e no boletim oficial. A vida está cheia de belezas assim. 

Os processos de produção de Arte Eletrônica contemporânea (pós-anos 1990) são discutidos sob a ótica da Cibernética de Segunda Ordem, cujos princípios consideram o observador durante a observação dos sistemas, analisando como circular a relação entre observador e observado. A metodologia empregada baseia-se na Teoria Fundamentada nos Dados, cujo argumento emerge do entrecruzamento do arcabouço teórico sobre o assunto com as informações coletadas através de observações, conversas e entrevistas. A análise se desenvolve em três capítulos, todos atravessados pela exploração das relações entre acidente e controle no campo da Arte Eletrônica. No primeiro capítulo levamos em consideração os aspectos conceituais e estruturais da produção artística em questão. No segundo, exploramos as relações que se tecem entre agentes criativos durante o processo, observando tal produção enquanto sistema social pautado em conversações. No terceiro, vislumbramos a experiência criativa coletiva enquanto possibilidade de construção de Espaços de Conhecimento, e arriscamos uma auto-crítica sobre o que apreendemos sobre o processo de produção da Arte Eletrônica. Nossas considerações finais trazem nossa apreensão para as relações entre a Arte Eletrônica e a Arquitetura, apontando para o caráter utópico de nossos argumentos.

Palavras-chave: Arte Eletrônica. Arte Contemporânea. Cibernética de Segunda Ordem. Processo de design. Acidente e controle. Cultura digital.

The production processes on Contemporary Media Art (post-1990's) are discussed through the Second Order Cybernetics perspective, whose principles study the observer while observing the system, and analyzes the relationship between observer and observed as a circular motion. The research methodology is based on the Grounded Theory. The argument emerges by blending together the theoretical framework on the subject with the information collected through observations, conversations and interviews. The analysis is developed in three chapters, all interrelated exploring the relationships between accident and control in the Media Art field. In the first chapter the conceptual structure of this artistic production is analyzed. In the second chapter, we explore the relationships that emerge between creative agents during the process, observing such production as a social system being ruled by conversation. In the third chapter, picturing the collective creative experience as means to the construction of Knowledge Spaces, we apply to the Architectural field what we learned about the production process of Media Art. Our final conclusions bring our perception to the relations between Media Art and Architecture leading to the utopian character of our arguments.

Keywords: Media Art. Contemporary Art. Second-Order Cybernetics. Design process. accident and control, digital culture. 



\section{SUMÁRIO}

INTRODUÇÃO

CAPÍTULO 1

MEDIA ART: UNIVERSO COMPLEXO DAS IMAGENS SINTÉTICAS

1.1 Contextualização

1.1.1 Conceitos

1.1.2 A produção artística nos anos 1960/70

1.2.1 Media art em movimento: o contexto pós anos 1990

1.2.1.1 0 potencial imersivo das CAVEs

1.2.1.2 Transição para a abertura aos espaços públicos e semi-públicos

1.2.2 Tendência ao espaço público

1.2.3.1 Interfaces tangíveis no espaço público

1.2.3.2 Mídias e performances no espaço público

1.3 Aspectos de um sistema estético

1.31 Media Art e Cibernética

1.3.2 Comunicação: interações, máquina-máquina, homem-máquina, homem-homem

1.3.3 Entre o acidente e o programa

1.3.4 Autopoiesis

1.3.5 Nossa experiência sob o olhar cibernético

\subsection{Considerações}

\section{CAPÍTULO 2}

ARTE E CIBERNÉTICA: DA META-TEORIA À META-EXPERIÊNCIA

2.1 A relevância da Cibernética de Segunda Ordem na compreensão da produção de Media Art

2.1.1 Cibernética: história, conceitos e contexto

2.1.2 Arte como sistema social

\subsection{A criatividade na era digital}

2.2.1 A criatividade e a autoria coletivas

2.2.2 Media Art e a Teoria Conversacional: o fazer enquanto processo de Comunicação 75

2.2.3 Processo: coordenação 
CAPÍTULO 3

META-CRÍTICA: ARQUITETURA E SÍNTESE DO CONHECIMENTO

3.1 A crítica da crítica: dimensões do invisível 101

3.1.1 Imersão e distanciamento 101

3.1.2 Caixa-preta 104

3.1.3 Media art, processos invisíveis e "uma história que não quer ser contada" 108

3.2 Construindo Espaços de Conhecimento

3.2.1 Definições

3.2.2 Cibernética, conhecimento e aprendizagem

3.2.3 Informação, subjetividade e espaço

REFERÊNCIAS 

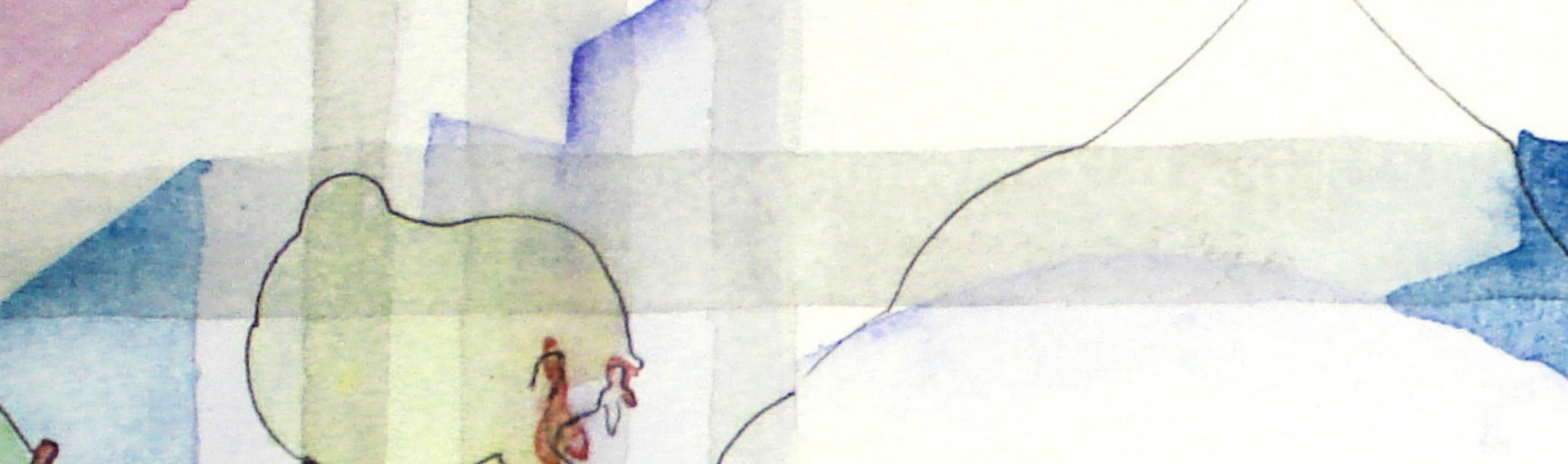

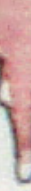

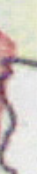

I
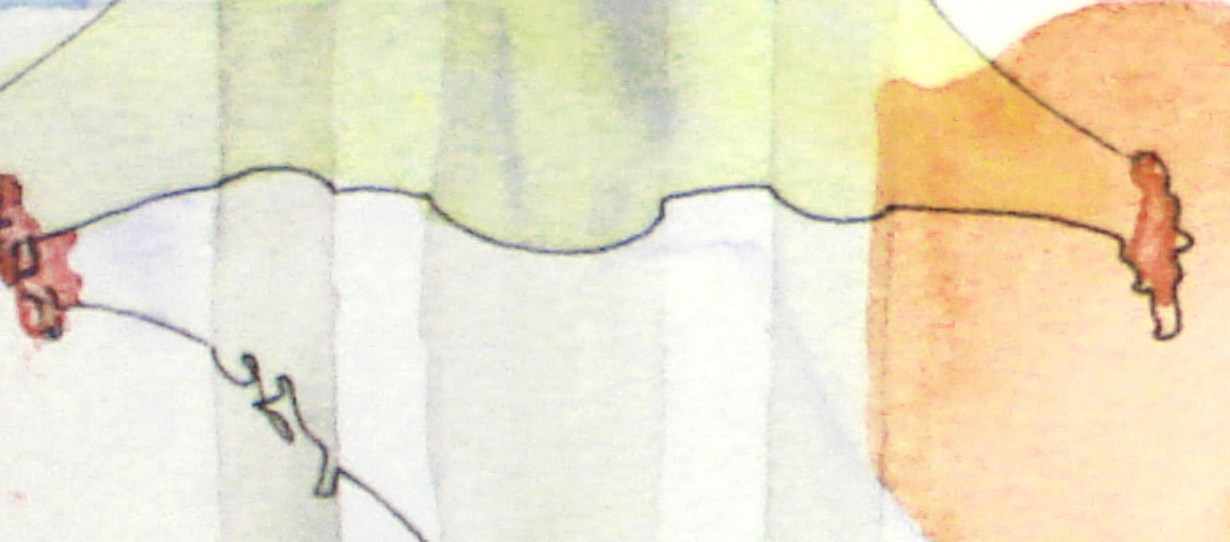

A dissertação aqui apresentada foi realizada dentro das linhas de pesquisa Processos de Design e Processos de Comunicação do Núcleo de Estudos em Habitares Interativos (Nomads.usp) do Departamento de Arquitetura e Urbanismo da Escola de Engenharia de São Calos da Universidade de São Paulo. Conduzida pela bacharel em Imagem e Som Graziele Lautenschlaeger, as atividades de pesquisa se desenvolveram sob a orientação da arquiteta e pesquisadora ciberneticista Profa. Dra. Anja Pratschke.

Com a formação em comunicação audiovisual e especialização em hipermídia, a pesquisadora desde a graduação se interessou pelas relações entre o espaço e as diferentes linguagens da Comunicação. A partir deste interesse, houveram simbióticas trocas com o grupo de pesquisa Nomads.usp, e a partir delas surgiu a possibilidade de realizar esta pesquisa de mestrado interdisciplinar, a qual se configurou como uma investigação dos processos na Arte Eletrônica e seus possíveis reflexos e diálogos com os processos na Arquitetura.

Além da História da Arquitetura evidenciar o diálogo com a Arte em investigações formais e conceituais, influenciando diretamente a prática profissional dos arquitetos, a riqueza da ambigüidade da Arquitetura como um campo de atuação entre a arte e a técnica (Cabral Filho, 2005) é, em certa medida, compartilhada pela Arte Eletrônica.

A metodologia empregada durante as investigações baseou-se na Teoria Fundamentada nos Dados (Grounded Theory), uma sistemática metodologia de pesquisa qualitativa, usada na área de ciências sociais e que cria uma argumentação baseada nas informações coletadas, a qual emerge ao longo do processo de pesquisa. Esta metodologia começa numa "situação de pesquisa" (Dick, 2005), na qual a tarefa do pesquisador é entender o que está acontecendo no cenário, e como as pessoas atuam seus papéis. Através de observações, conversas, entrevistas e posterior entrecruzamento com a bibliografia disponível, a teoria começa a emergir, resultando na redação da dissertação.

Além do acesso à bibliografia especializada; realização de entrevistas junto a artistas, curadores e teóricos; e visitas a centros de arte e mídia nacionais e europeus; nosso mergulho na coleta de dados sobre o universo estudado contou com a produção de uma instalação interativa. A oportunidade de lidar com os processos de criação e execução neste campo contribuiu 
profundamente para o delineamento dos pontos essenciais e críticos sobre tal produção.

Neste contexto, o objetivo central de nosso trabalho foi o de analisar os processos de produção na Media Art contemporânea - pós-anos 1990 a partir do olhar da Cibernética de Segunda Ordem. Para tal, atravessamos três principais eixos de discussão, concretizados nos três capítulos desta dissertação.

No capítulo 1, intitulado "Media Art: o universo complexo das imagens sintéticas", apresentamos o contexto e as características estruturais da produção de Arte Eletrônica, observando-a na seqüência enquanto um sistema estético, e relacionando seus aspectos àqueles da Cibernética de Segunda Ordem.

Nossa aproximação com a Cibernética se baseia nos princípios da Cibernética de Segunda Ordem, por esta, além de considerar o observador durante a ação de se observar os sistemas, analisa a relação circular entre observador e observado. Concentramos esforços na elaboração de um pensamento sobre a construção do conhecimento baseada não apenas na objetividade da pesquisa e dos métodos científicos, mas também na experiência estética e nas impressões que os envolvidos num determinado cenário de produção artística possuem.

Como desdobramento dessa perspectiva, no capítulo 2, nomeado “Arte e Cibernética: da meta-teoria à meta-experiência" o foco da discussão está no âmbito das relações que se tecem entre os atores envolvidos no cenário da produção colaborativa da Arte Eletrônica. Para isso, discutimos tal produção enquanto sistema social, pautado em conversações, que afetam tanto os processos de criação quanto o próprio conceito de criatividade.

No capítulo 3, "Meta-crítica: arquitetura e síntese do conhecimento", novamente nos remetendo aos conceitos da Cibernética de Segunda Ordem, nos propusemos a avaliar criticamente nossa experiência e análise como uma metodologia possível para a construção de Espaços de Conhecimento.

Os três capítulos são costurados pelo tema das relações entre acidente e programa, aspecto que entendemos como crucial para a compreensão da complexidade cibernética de nosso objeto de análise.

No item reservado às Considerações finais, sintetizamos e relacionamos os conceitos trabalhados nos capítulos anteriores, propondo que nosso mergulho na teoria e na prática da Arte Eletrônica pode se constituir como referência para experiências de pesquisa e criação no campo da Arquitetura. Procuramos apontar caminhos e necessidades futuras identificadas ao longo de nosso processo de pesquisa, análise e síntese.

Tanto nosso interesse sobre o assunto quanto a perspectiva adotada 
se relacionam com uma abordagem humanista sobre o desenvolvimento das mídias e com o reconhecimento da importância da difusão da experiência do conhecimento na construção da civilização e da história da humanidade.

Além disso, esperamos que nosso estudo sobre processos no campo da Arte Eletrônica possa contribuir para o enriquecimento de referências de processos de criação e produção das espacialidades híbridas da era eletrônicodigital, alimentando as conversações entre a Arte e a Arquitetura. 



\subsection{Contextualização}

\subsubsection{Conceitos}

Para início de interlocução, parece-nos essencial elucidarmos alguns conceitos que serão tomados como pressupostos na leitura de nosso trabalho.

Quando nos referirmos ao termo flusseriano "imagens sintéticas", estamos lidando com uma noção ampliada do termo imagem, e não àquela correspondente à sua etimologia. Apesar da inadequação do termo "imagem" ter sido mencionada por diversos autores - por Vilém Flusser, ou mesmo Edmond Couchot ou Oliver Grau - não nos dispusemos aqui a arriscar pretensiosamente alguma sugestão que o substitua, mas tentaremos delinear em detalhes nossa compreensão acerca das características das "imagens sintéticas".

Atualmente testemunhamos a transformação da imagem numa entidade espacial virtual, gerada por computação, inclusive capaz de se transformar autonomamente, e atuante na esfera sinestésica. Por essas razões as imagens sintéticas estão transformando nossa percepção e nosso conceito de imagem na direção de um espaço que proporciona experiências multisensoriais e interativas com dimensões temporais. Com essas características, segundo - historiador alemão de arte e mídia Oliver Grau¹, as imagens sintéticas inauguram a possibilidade de descrevermos coisas que antes eram impossíveis de se representar (Grau, 2007, p.6-7).

O historiador de arte e psicólogo alemão Rudolph Arnheim, ao se referir à "imagens" diz respeito a duas coisas diferentes, mas intimamente relacionadas. Para ele, de um lado temos imagens ao usarmos nosso sentido da visão, quando vemos objetos físicos, que podem ser objetos estéticos: esculturas, pinturas, instalações, etc. De outro, numa perspectiva mais universal, são também imagens nossos pensamentos, nossas invenções e fantasias, como manifestações sensoriais não produzidas pela presença de objetos físicos. Enfatiza Arnheim: "além disso, imagens podem ser imóveis como rochas ou cheias de ação como organismos vivos" (Arnheim, 2007 apud Grau, 2007, p. 15, tradução nossa²).

\footnotetext{
1 Oliver Grau é historiador de arte e mídia alemão, cujos estudos estão focados em Ciência da Imagem, Modernidade, Arte Eletrônica, Cultura do século XIX e Arte Italiana Renascentista. Atualmente é professor e chefe do Departamento de Ciência da Imagem na Danube University Krems.

2 Excerto original: "furthermore, images may be immobile like rocks or full of action like living bodies" (Arnheim, 2007 apud Grau, 2007, p. 15).
} 
Para compreendermos as imagens sintéticas, tanto no nível constitutivo quanto no nível semântico, precisamos retomar alguns principais aspectos colocados pela situação cultural emergente, a cultura eletrônico-digital. No âmbito constitutivo consideramos a zero-dimensionalidade das imagens sintéticas como fator essencial para sua compreensão. Segundo o comunicólogo tcheco naturalizado brasileiro Vilém Flusser, a zero-dimensionalidade das imagens sintéticas compõe um modelo fenomenológico da história da cultura, visto pelo autor como uma dança em torno do concreto. Interrompidos periodicamente ao longo da história por passos de volta ao concreto, os homens, seus pensamentos e criações sempre dão passos rumo à abstração (Flusser, 2008, p.18).

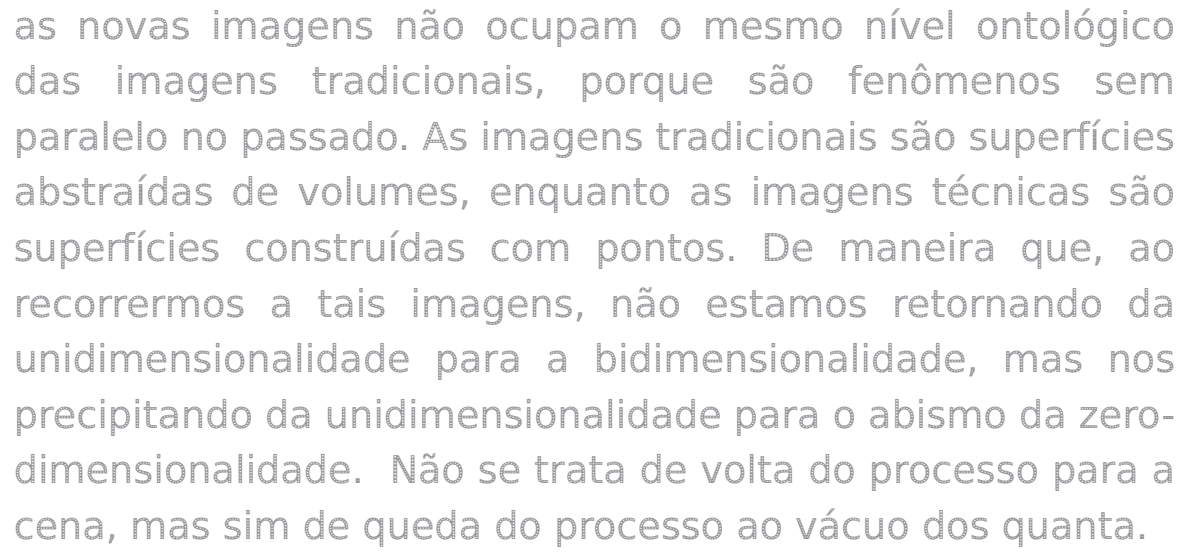

Flusser, 2008, p.15

Para Flusser, desde os primórdios atravessamos fases culturais baseadas na abstração de diferentes maneiras. Aos poucos subtraímos as dimensões, atravessando desde a tridimensionalidade até a zero-dimensionalidade. Por exemplo, quando demos início à manipulação de objetos e ferramentas, demos um passo para a abstração do tempo, o que nos trouxe a circunstância. Outro gesto cultural abstraidor é a nossa ênfase cultural no sentido da visão, que constitui-se como a abstração da profundidade da circunstância através da imagem. A noção de projeto e nossa tendência à conceituação também é um gesto abstraidor, rumo a unidimensionalidade. O cálculo e a computação, gestos enfatizados na cultura eletrônico-digitial, seriam, o gesto abstraidor rumo à zero-dimensionalidade, à realidade não-dimensional dos pontos e dos intervalos entre eles (Flusser, 2008).

Ao passo que a criação das imagens tradicionais parte do concreto ao abstrato, as "imagens sintéticas", em movimento oposto, são criadas a partir do universo abstrato na direção do universo concreto. É sobretudo nesse movimento que são criadas as proposições de Media Art discutidas neste trabalho. 
O universo zero-dimensional de pontos da era do cálculo e da computação nos exige um nível de consciência "pós-histórico", ainda não propriamente assimilado por nós. E, as "imagens sintéticas" produzidas através de nossos "aparelhos" eletrônico-digitais são

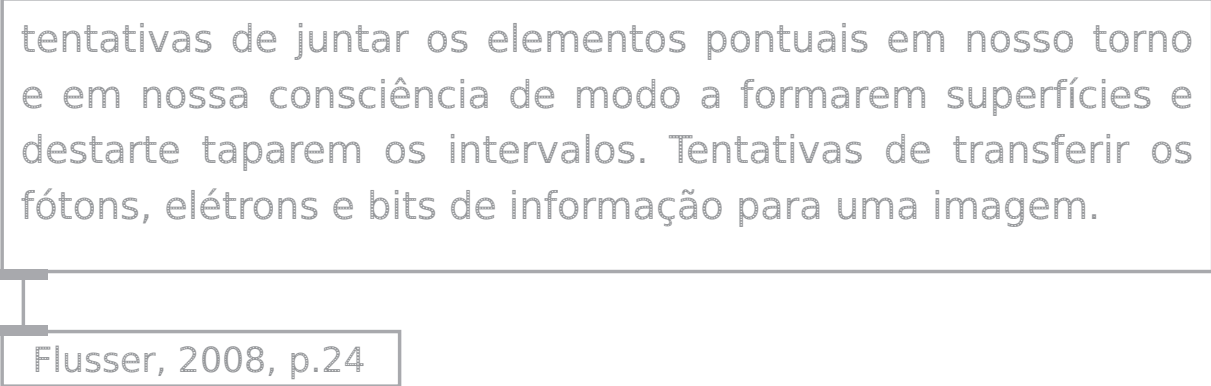

Segundo este argumento de Flusser, através de nossos "aparelhos" podemos imaginar o para nós inimaginável.

No campo das artes, como extensão e sinonímia das práticas criativas das imagens sintéticas, é recorrente uma série de terminologias diferentes. No entanto consideramos que delinear suas características faz-se mais essencial do que julgar uma ou outra terminologia como mais importante. O campo artístico examinado neste trabalho compreende as seguintes premissas: (1) constitui-se como uma reação às teorias estéticas centradas no objeto de arte, sendo favorável à reflexão sobre o processo, o sistema e o contexto; (2) lida com a questão da vasta interconexão entre diferentes áreas do conhecimento; e (3) discute e atua na redefinição dos papéis do autor e do observador (Giannetti, 2006). Para designá-lo, optamos pelos termos mais coerentes com nossa abordagem: Arte Eletrônica, Media art, Arte Computacional ou ainda, Arte Programmata.

O uso dos termos "técnicos" nessas terminologias é uma maneira apenas de distinguir (sem distanciar) o campo da Arte Eletrônica das manifestações artísticas que utilizam outros recursos que não aqueles baseados nas tecnologias eletrônicas e/ou digitais, tais como as audiovisuais, informáticas e telemáticas. Outras manifestações artísticas que usam meios não-tecnológicos para desenvolver a inter-relação entre obra e observador, se mencionadas, serão chamadas de Arte Participativa (Giannetti, 2006).

Apesar de ser fruto da emergência da multiplicidade e convergência midiáticas, ambas conseqüências da evolução do campo da eletrônica, a história da Media Art não é algo possível de se analisar apenas a partir das "evoluções" da História das Mídias e da História da Arte (Broeckmann, 2007). Para o ex-diretor do Transmediale - Festival de Arte Contemporânea e Cultura Digital de Berlim, Andreas Broeckmann³:

\footnotetext{
3 Andreas Broeckmann estudou História da Arte, Sociologia e Estudos das Mídias. Trabalhou como gerente de projeto no V2 Institute for Unstable Media em Rotterdam, entre 1995-2000. De 2000 até sua substituição por Stephen Kovats em 2007, foi diretor artístico do Transmediale - Festival for Art and Digital Culture Berlin.
} 
A recente reavaliação da arte conceitual como uma precursora
da arte midiática computacional é uma indicação de que os
conceitos da media artse desenvolveram em um meio cultural
mais amplo, em que teoria de jogos, cibernética, viagem
no espaço, televisão, genética, e outras áreas da atividade
humana exerceram impacto sobre as práticas culturais. No
entanto, há muito mais media art “avant la lettre" em outros
períodos históricos que podem ser levantados através de
paradigmas de uma teoria estética que não toma a tecnologia
digital como sua chave principal, mas preferivelmente tomam
a máquina como um princípio produtivo e transformativo.
Broeckmann, 2007, p.194, tradução nossa4

Consideramos o campo da Media Art como um continuum da arte contemporânea em geral e como resultado de inúmeras linhas de força das transformações paradigmáticas ocorridas no mundo no último século. No entanto, não podemos ignorar que as práticas artísticas mediadas pelas tecnologias eletrônico-digitais sejam caracterizadas por processos sintéticos evolutivos e que o suporte tecnológico contribui para a formação e definição de uma determinada estética. A mútua influência entre sociedade e tecnologia e alterações na relação entre ambas inevitavelmente provocam reverberações no campo das artes e no processo criativo (Popper, 1975).

Para melhor compreender as mudanças desencadeadas nas últimas décadas e realçar as características de nosso objeto de análise, desenvolveremos um breve percurso histórico que remonta às conjunturas da arte pós-1960, período recheado de referências para a produção da Media Art contemporânea.

\subsubsection{A produção artística nos anos 1960/70}

Caracterizado como período de lutas e emancipações significativas no campo político do mundo ocidental, os anos 1960, no campo das artes foi marcado pelos desdobramentos da crise da representação, iniciada desde a segunda década do século XX. Múltiplos autores apontam nesse período o surgimento de um movimento na direção da desmaterialização do objeto artístico, em direção à não-representação. O objeto representado aos poucos desaparecia e cedia espaço para o objeto concreto, que não era mais produzido

\footnotetext{
${ }^{4}$ Excerto original: "the recent reevaluation of conceptual art as a precursor to digital media art is an indication that the concepts of media art have evolved in a broader cultural environment in which game theory, cybernetics, space travel, television, genetics, and other areas of human endeavor were having an impact on cultural practices. However, there is much more media art "avant la lettre" in other historical periods that can be reared through the paradigms of an aesthetic theory that does not take digital technology as its main cue, but rather takes the machine as a productive and transformative principle" (Broeckmann, p.194, 2007).
} 
pelas mãos do artista, mas sim um objeto industrial elevado à condição de "obra de arte", a citar os ready-made do artista dadaísta e surrealista francês Marcel Duchamp. Ousado e crítico, a fim de questionar o valor do objeto artístico, ele sugeriu nos anos 1960, que uma tela de Rembrandt fosse usada como tábua de passar (Weibel, 2005, p.1030).

Por outro lado, nas manifestações da arte óptico-cinética - vide Yaacov Agam (1928), Alexander Calder (1898-1976), Jean Tinguely (1925-1991), Victor Vassarely (1908-1997), László Moholy-Nagy (1895-1946), etc. -, cujas obras se completavam a partir da participação física/mecânica/material do "observador", a mera representação é renunciada a favor do movimento e da luz concretos, que se tornam meios de produção artística.

Fenômenos perceptivos e ilusões óticas foram usados não como instrumentos, mas como motivos, não como meios de representação, mas como desencadeadores de experiências perceptivas nas quais o observador era agora um fator crucial.

Weibel, p.25, 2007, tradução nossa5

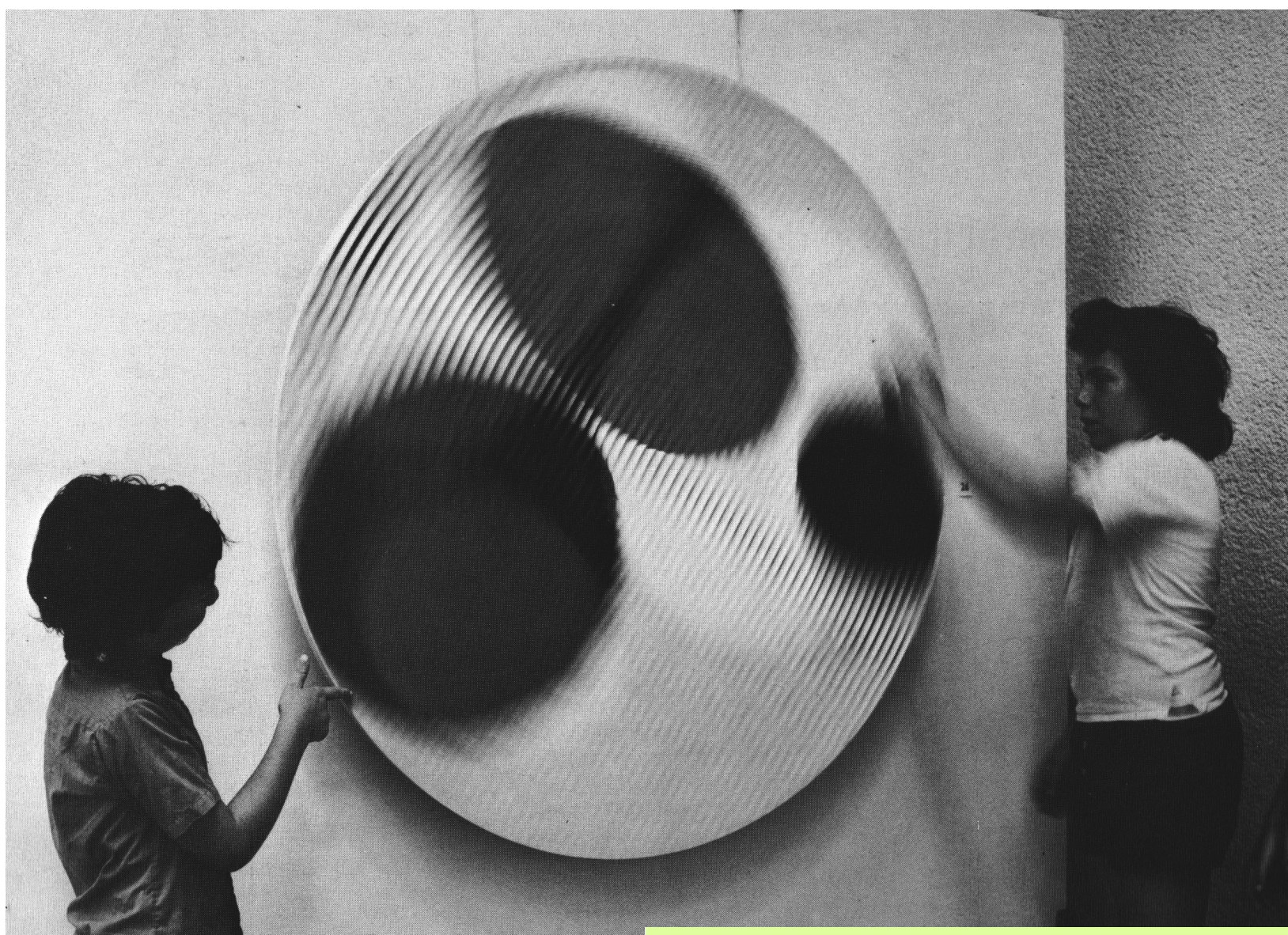

Figura 1.1: "Métamorphose" (Yaacov Agam, 1957, foto: Ron Erde) exemplo de arte óptico-cinética. Fonte: Popper (1975. p.24).

5 Excerto original: "Perceptual phenomena and optical illusions were used not as instruments but as subjects, not as means of representation, but as activated preceptual experiences in which the viewer was now a crucial factor" (Weibel, 2007, p.25). 
Tais manifestações são consideradas por diferentes autores como uma vertente de produção artística marcante no desdobramento das transformações sofridas pela arte contemporânea. É comum que historiadores da arte e das mídias, a citar Andreas Broeckmann, Peter Weibel e Frank Popper, relacionem o surgimento das primeiras manifestações de dependência do observador (mais tarde nomeado usuário ou interator), a essas obras com dispositivos mecânicos e ópticos, anunciando-as como precursoras de aspectos como a interatividade e a virtualidade na arte. À medida que se espera dos observadores da arte óptico-cinética que estes pressionem botões ou movimentem elementos disponíveis, identifica-se nessas condições os primeiros apelos à interação e às atualizações de algo que se encontra em potência (Lévy, 1996). Em publicação editada por Oliver Grau, Peter Weibel afirma que as "artes cinética e óptica estão sendo redescobertas" e que "elas estão sendo reconhecidas como desenvolvimentos que correm paralelamente com a emergência da arte computacional, dos gráficos e animações computacionais" (Weibel, 2007, p.21, tradução nossa6).

Essas relações foram exploradas também pelo historiador de arte e tecnologia francês FrankPopper. Emsuas publicações “Ledéclindel'objet"(1975) e "Art, action et participation: I'artist et la créativité aujourd'hui" (1980) , o autor apresenta e discute as inúmeras manifestações desencadeadas no processo de transformação da arte, argumentando que as indissociáveis relações entre a participação do "espectador" e a exploração do ambiente circundante na produção artística colocavam em cheque as formas artísticas tradicionais, e eram fundamentais no processo de revisão das relações entre artista, obra de arte e público. Essas novas condições, segundo o autor, preparavam o caminho rumo a uma arte democrática (Popper, 1975). Esse percurso é sintetizado pelo autor no esquema abaixo:

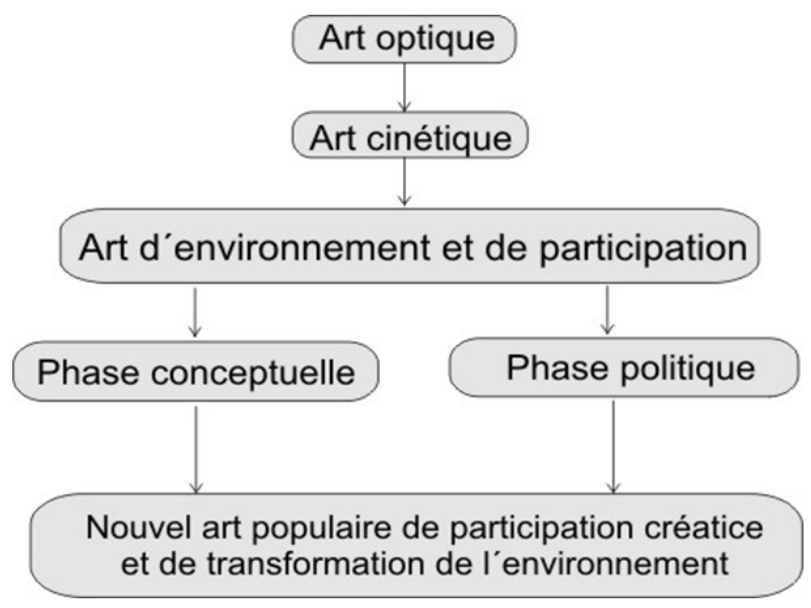

Figura 1.2: Esquema que sintetiza o argumento central de Frank Popper em "Art, action, participation: I'artiste et la créativité aujourd 'hui". Fonte : Popper (1980, p. 332).

\footnotetext{
6 Excerto original: "Kinetic art and op art are being rediscovered." " "they are being recognized as developments that ran parallel with the emergence of computer art, of computer graphics and animation" (Weibel, 2007, p.21).
} 
Sobre a transformação na arte que se intensifica após os anos 1960, Popper afirma que ela se caracterizou por quatro principais tendências: (1) o questionamento da própria noção de arte, considerando a predominância da sugestão e do processo criativo sobre a obra em sí; (2) a valoração da linguagem como ferramenta crítica; (3) a introdução de sistemas científicos e tecnológicos como alicerce de uma estética não mais perceptível apenas em termos visuais, mesmo que esta fosse apresentada em museus e galerias; e (4) o estabelecimento de novas relações com o ambiente circundante, a partir da criação em escala monumental e da incorporação de elementos artísticos no ambiente cotidiano (Popper, 1980).

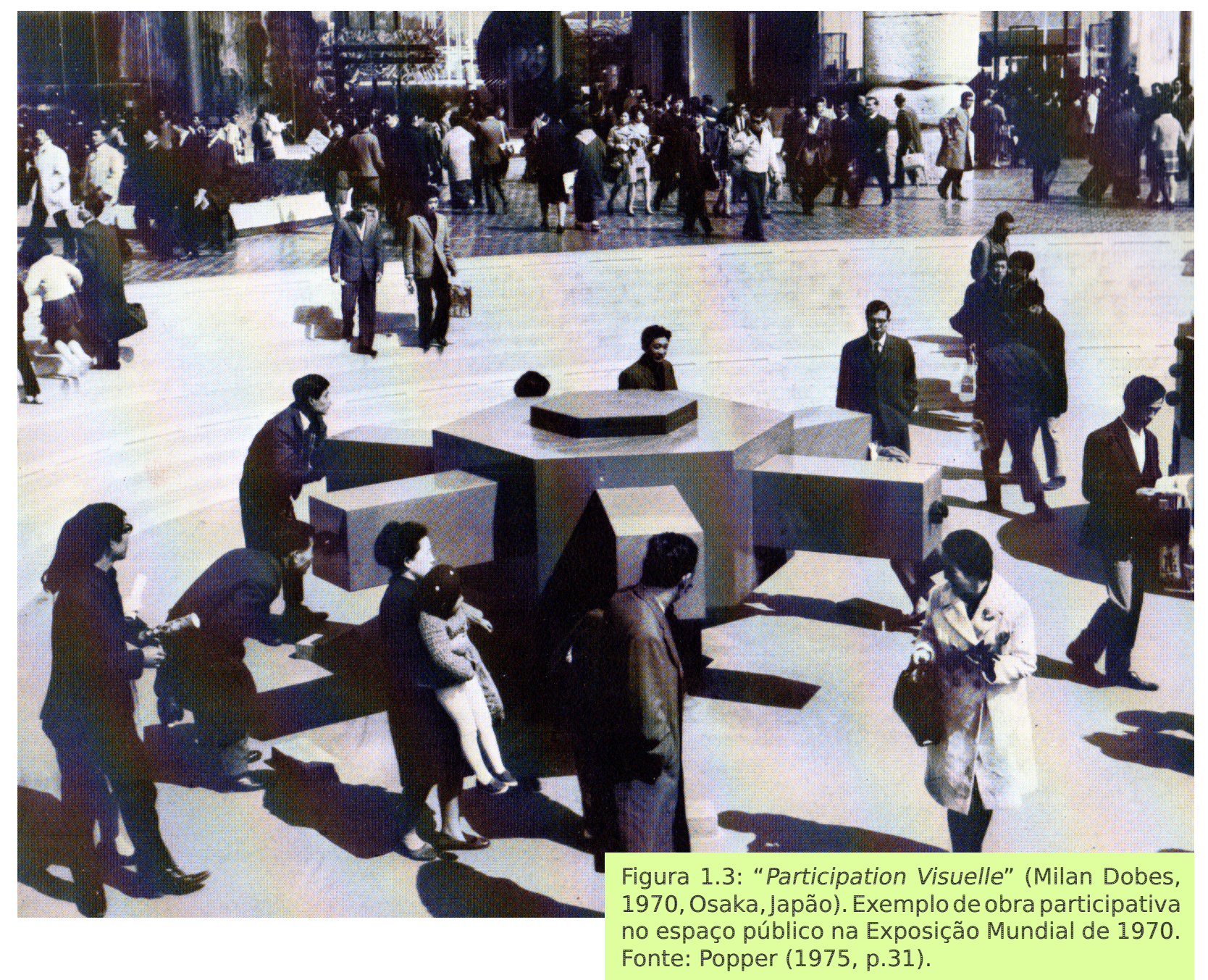

No Brasil, exemplos significativos destas direções apontadas por Popper são as obras de Lygia Clark e Hélio Oiticica. Suas obras experimentalistas dos anos 1960 e 1970 propunham um vigoroso entrecruzamento entre arte e vida e, atravessando o conceito de "não-objeto" cunhado por Ferreira Gullar, articularam uma tipologia artística para além do âmbito representacional, baseada em "experiências artísticas vivenciais centradas no corpo"(Sperling, 2008, p. 118).

A trajetória de Clark merece destaque. Na totalidade de sua obra, cada uma de suas proposições, "desde a abertura das pinturas, processa uma diferenciação da anterior, a qual, por sua vez, já contém outra em potência; 
e todas são manifestação imanente de sua concepção de ação artística" (Sperling, 2008, p.127). Como que um "organismo vivo", de "Ovo" (1958), passando por "Casulo" (1958) e "Bichos" (1960), a "Caminhando" (1963), o sentido cumulativo de suas "proposições nascem e crescem nelas mesmas e noutras" (Oiticica, 1986 apud Sperling, 2008, p.119)

O movimento de se conceituar e desmaterializar o trabalho artístico, compreendendo-o enquanto processo, culminou também na teoria estética da "Obra Aberta" do filósofo e crítico literário italiano Umberto Eco (1962), na qual ele discute a abertura do trabalho de arte. Mesmo que este se apóie numa dada forma, na materialidade de objetos, ele deve permitir ao fruidor um certo grau de liberdade interpretativa.

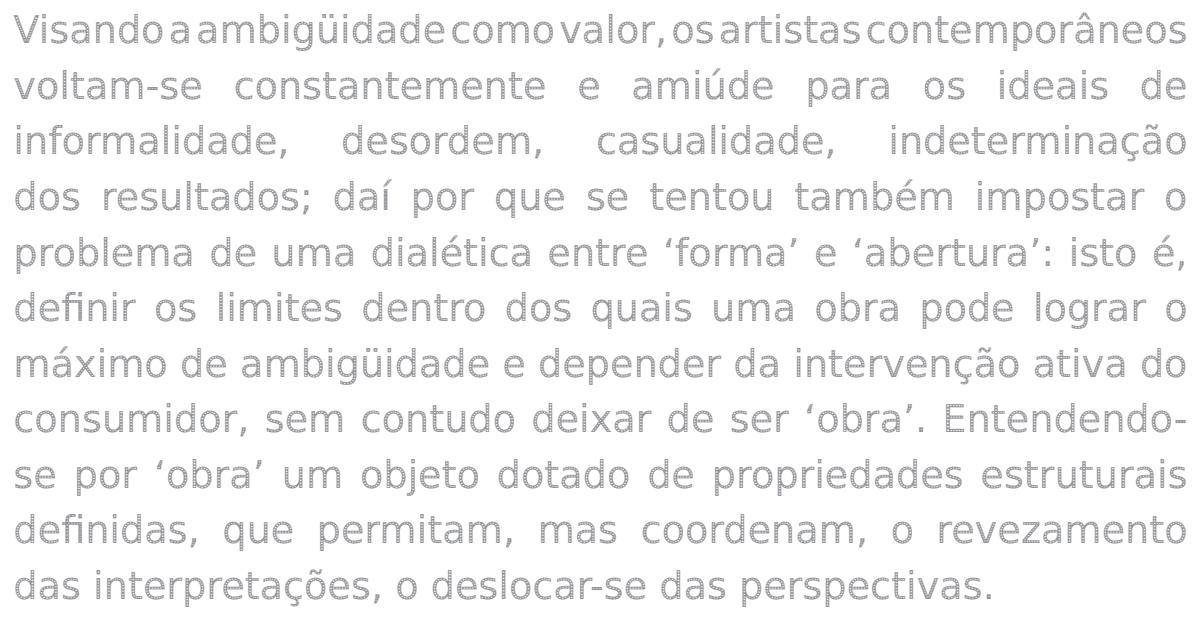

Eco, 1988, p.22-3

Por mais que a abertura, entendida como ambigüidade fundamental da comunicação artística, é uma constante de qualquer obra em qualquer tempo, Umberto Eco foi um dos precursores a discutir esteticamente esta abertura (Weibel, 2005).

Complementandoeste processo complexo enão-lineardetransformações, outras formas de negação dos objetos se desenvolvem por meio de ações, eventos e situações artísticas - happenings e performances - realizadas, por exemplo, pelos artistas Situacionistas e pelo grupo Fluxus. Nestes casos, em detrimento das "instruções de uso" são exploradas as "instruções para a ação", qualidade que ressalta ainda mais o declínio do objeto de arte e a recuperação da valorização do processo, tanto na instância da criação, como na da fruição artística.

Oiticica, por exemplo, no conjunto de sua obra, ao mencionar a noção de "projeto", refere-se a algo a ser concretizado, ao ato de projetar(-se), ao lançar-se em proposições futuras. Tal referência compõe a sua investigação sobre o que há de vivencial nos processos: as possibilidades abertas do comportamento, mais do que as estruturas abertas do objeto. Ao considerar 
a ação comportamental como força criativa, Oiticica através de suas obras contribui na dissolução da dicotomia sujeito-objeto tradicionalmente presente na arte da representação, e na construção de campos inter-subjetivos moldados pela experiência do sujeito (Sperling, 2008).

Com base nessas proposições, para alguns historiadores de arte contemporâneos, ao passo que a Modernidade culmina na dissolução da "obra de arte" enquanto objeto ou superfície; o que se tem nomeado de PósModernidade na Arte, se constitui como o período de experimentações no campo da "arte programmata", ou "algorithmic art"(Weibel, 2007).

Arte programmata é um termo utilizado pela primeira vez por Umberto Eco na ocasião em que ele redigia o texto de apresentação da mostra "Arte Programmata - arte cinetica, opere moltiplicare, opera aperta" (Milão, 1962), curada por Bruno Munari e Giorgio Soavi e cujo título assimilou o termo cunhado por Eco (Weibel, 2007, p.24). Neste texto, o autor dissertava sobre as relações entre o acidente e o programa no fazer artístico, e a noção de arte programmata compreendia as produções que incorporavam princípios de algoritmos em suas propostas.

Algoritmos são definidos como uma seqüência finita de instruções claramente definidas e não ambíguas, a serem executadas num período de tempo finito e com uma quantidade de esforço finita (Weibel, 2007). Uma analogia simplificada de um algoritimo é a de uma receita, uma tarefa a ser cumprida. Eles podem repetir passos (iterações) ou demandar tomada de decisões (tais como comparações ou lógica) até que a tarefa seja completada. Um algoritmo corretamente executado não irá resolver um problema se estiver implementado incorretamente ou se não for apropriado ao problema.

No campo da Arte, podemos dizer que há dois diferentes tipos de uso de algoritmos influenciando a interatividade entre o trabalho artístico e a audiência: um manual, mecânico e analógico - como nas performances e na arte óptico-cinética, por exemplo -; e um segundo, eletrônico e digital - como na Arte Eletrônica (Weibel, 2007, p.24).

Nas obras participativas de Lygia Clark (figura 1.4), seu conceito de participação tangencia a noção de arte algorítmica por sugerir e incitar, a partir da inter-relação entre propositor, objetos e participantes, a execução da tarefa de concretizar efemeramente, uma "situação espaço-temporal" inicialmente em potência.

A citar a produção de Media Art contemporânea, vale lembrar que as ferramentas eletrônico-digitais permitem a incorporação, por exemplo, de algoritmos genéticos e de inteligência artificial, que além da assimilação das interferências dos inputs do interator, atribuem uma condição de autonomia ao trabalho de arte. Como exemplo, tomemos a instalação interativa "Life 


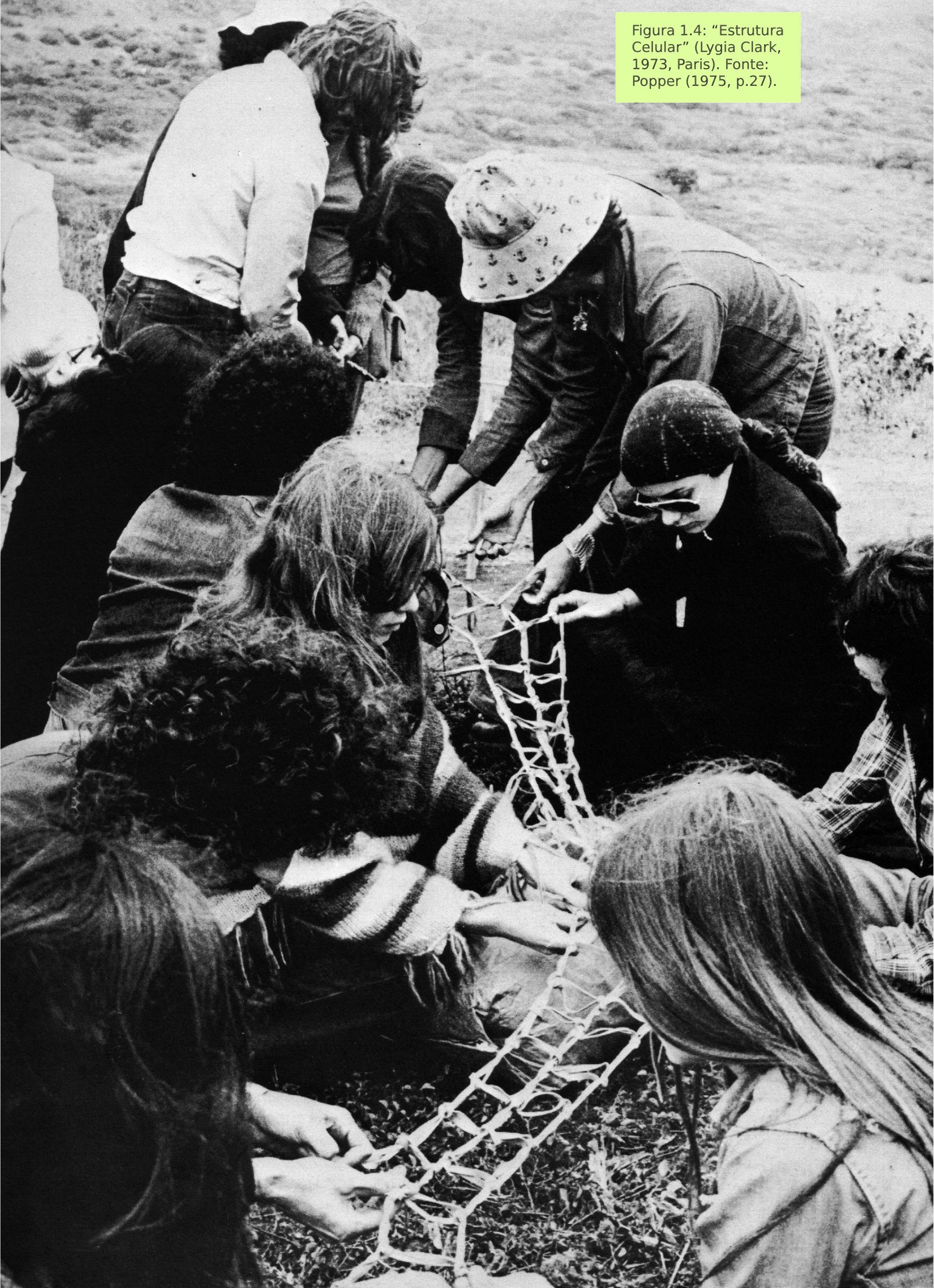


Writer" (figura 1.5), de Christa Sommerer e Laurent Mignonneau. A interface é composta por uma máquina de escrever antiga e pela projeção de imagens num pedaço comum de papel, as quais coincidem com a posição do eixo giratório da máquina. Quando o interator aperta as teclas da máquina, letras comuns aparecem projetadas no papel. Quando o interator empurra o retorno de carro da máquina, as letras projetadas se transformam em pequenas criaturas de vida artificial. As criaturas são baseadas em algoritmos genéticos em que o texto é usado como código genético, determinante do comportamento e dos movimentos das criaturas (Sommerer; Mignonneau, 2006).

Ao contrário do que se tende a criticar, o uso de algoritmos na arte não impede que o artista contemporâneo crie proposições que trafeguem por contextos de indeterminação. As relações entre acidente e programa envolvem todas as atividades criativas, em suas múltiplas fases, desde o surgimento da ideia até sua confrontação junto ao público. O uso de algoritmos dá margem

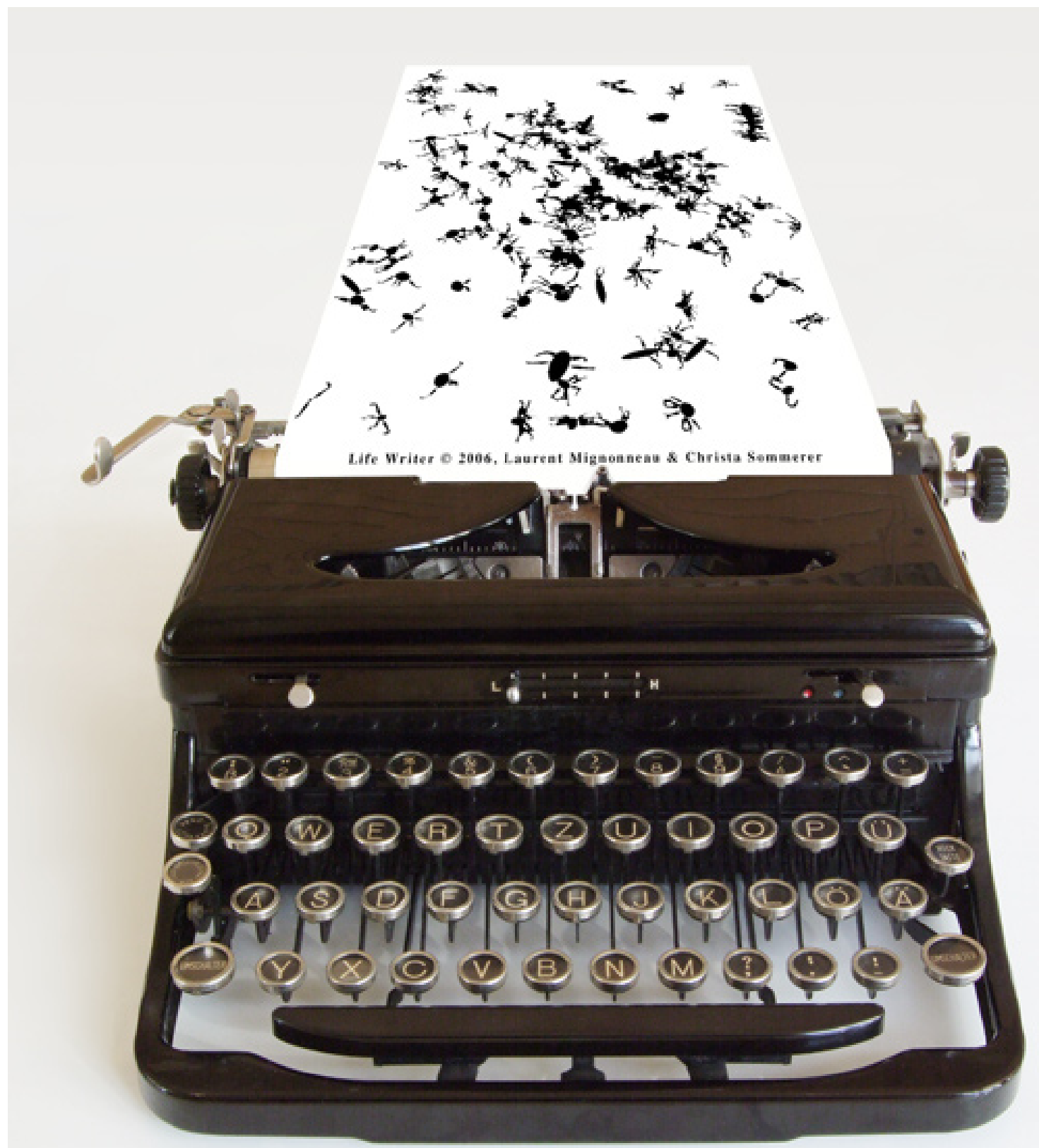

Figura 1.5: "Life Writer": exemplo de uso de algoritmos genéticos e inteligência artificial em Media Art. Fonte: Sommerer; Mignonneau (2006, website). 
à constituição de uma arte cada vez mais engajada na proposição de ações, que demanda cada vez mais atividade por parte do interator. Em diálogo com a noção de "obra aberta" de Umberto Eco, Peter Weibel comenta:

Na sociedade da informação, o objeto artístico não apenas se torna a "obra aberta" de Eco, mas a obra como tal desaparece e é substituída por instruções para atuação, para comunicação ativa e opções para ação. Campos abertos de atuação significam o surgimento de novas alianças entre autor, obra e observador, em que novos atores como máquinas, programas, usuários múltiplos agem, substituindo o objeto artístico clássico.

Weibel, 2005, p.1034, tradução nossa ${ }^{7}$

A abertura das proposições artísticas está no domínio da virtualidade. Tanto os elementos móveis, os contornos ilusórios e os volumes aparentes das artes óptico-cinéticas, quanto o projetar(-se) de Oiticica e a potência do "vir-a ser" de Clark nos remetem ao universo da virtualidade, à existência de um complexo de potência, em vias de ser atualizado pelo participante/interator (Lévy, 1996).

A História da Arte nos mostra que a esfera do movimento virtual e dos corpos virtuais se alongam da pintura à escultura, da superfície plana ao espaço tridimensional, e que já nos anos 1920 o termo "virtual" começou a ser utilizado no lugar de "ilusório".

Weibel, 2007, p.31, tradução nossa ${ }^{8}$

Assim, ao contrário do que o senso comum tem como dado, as características de programabilidade, imersão, interatividade e virtualidade, não aparecem nas obras de Arte Eletrônica produzidas a partir da década de 1970; elas estavam presentes em manifestações anteriores, como na arte óptico-cinética e nos happenings e performances dos anos 1950 e 1960, quando o essencial não era mais o objeto por si só, mas o confrontamento do "espectador" com uma situação perceptiva (Popper, 1975).

Além dessas relações, a prática da Arte Eletrônica - orientada na direção

\footnotetext{
7 Excerto original: "In the information society, the artistic object not only becomes Eco's 'open artwork', but the work as such disappears and is replaced by instructions for enactment, for communicative action and options for action. Open fields of enactment mean new alliances arise between author, work and observer, in which new actors such as machines, programs, multiple users operate, replacing the classical art object" (Weibel, 2005, p.1034).

8 Excerto original: "Art history shows us that the realm of virtual movement and virtual bodies stretches from the painting to the sculpture, from plane surface to the three-dimensional space, and that already in the 1920s the term 'virtual' had begun to be used instead of 'illusory"' (Weibel, 2007, p.31).
} 
de uma concepção estética inerente às experiências e aos contextos de criação, exibição e recepção de obras interativas - encontra embasamento em correntes teóricas diretamente influenciadas pela Cibernética e pela Teoria da Informação, as quais concebem o parâmetro "informação" como a chave para o entendimento dos processos estéticos (Giannetti, 2006, p. 16). Essas correntes teóricas, através da expansão do conceito de arte para o de sistema (arte além da arte), acaba por reproduzir o modelo interativo e interconectado da situação sócio-cultural emergente, descrita com todos seus paradoxos por Flusser.

Claus Pias, professor alemão de filosofia das mídias digitais da Universidade de Viena, em artigo sobre as relações entre a Cibernética e a revisitação do conceito de interatividade na Media Art no período posterior a meados dos anos 1990, fala que a arte computacional européia, quando emergiu nos anos 1960 não era interativa, se limitando a divisão estrita da tríade: input, processamento, output, o que a caracterizava como uma arte chamada por ele de interpassiva, apesar de filosoficamente fundamentada. Nesta mesma publicação, na medida em que critica a visão não-epistêmica do uso das tecnologias eletrônico-digitais, Pias concorda que a Media art e seu potencial interativo estão arraigados na produção artística dos anos 1960, e ganham consistência com o início da Cibernética de Segunda Ordem, quando coisas epistemológicas já se tornaram técnicas (Pias, 2005).

Com base nesses autores apreendemos que os três mais significativos movimentos artísticos dos anos 1960 - arte óptico-cinética, happenings e Fluxus, imagens sintetizadas por computador - têm sido relacionadas entre si e reconsideradas sob a ótica dos algoritmos, da virtualidade e da interatividade. Dadas essas relações, emanam perguntas inevitáveis: qual a natureza dessa potência de transformação que surge nos anos 1960 e se prolonga até os dias atuais? O que há de novo? Por que o novo é tão importante? E ainda, em que medida a tecnologia potencializa as relações entre as pessoas e a partilha de conhecimento?

\subsection{Media art pós anos 1990}

Feitas as considerações sobre a origem e o contexto das principais características das obras de Media Art, no item a seguir, a partir de diferentes exemplos, procuramos delinear os aspectos da produção após os anos 1990.

\subsubsection{Media art em movimento: o contexto pós anos 1990}

Vivemos atualmente num período histórico em que nos questionamos o 
que acontece e como devemos agir quando ocorrem profundas transformações nas diferentes técnicas de representação: arte, ciência e política - todas de uma vez (Weibel, 2005, p.1021-4).

As transformações não cessam e estão no mesmo ritmo frenético que assola os modos de vida e dos avanços tecnológicos contemporâneos. Inseridas nesse mesmo movimento, a produção de Arte Eletrônica assume diferentes focos entre os anos 1990 e os anos 2000, e isso não apenas em função das condições técnicas disponíveis na época, mas sobretudo nas diferenças de contextos sócio-culturais dos períodos correspondentes.

Enquanto na década de 1990 as experimentações giravam em torno da revolução técnica na produção de imagens e da criação de espaços virtuais e imersivos, através de tecnologias como Realidade Virtual (RV), Inteligência Artificial (IA) e de equipamentos como eyephones e luvas; nos anos 2000, com o avanço das tecnologias de telecomunicações (banda larga, wireless, $3 G$, entre outras), o aumento considerável do número de usuários da internet, bem como o de discussões sobre telerobótica, nanotecnologia, entre outros assuntos, o foco se transfere para as hibridizações, emergindo experimentos em Realidade Aumentada (RA) 9 e em computação ubíqua. Segundo o mídiaartista e professor alemão Joachim Sauter ${ }^{10}$, o contexto dos anos 2000 acaba por permitir mais intervenções em espaços públicos e semi-públicos, e fez com que a Arte Eletrônica começasse a atravessar um amadurecimento na produção, hoje em dia muito mais orientada pelos conceitos e conteúdos veiculados do que pelas ousadias dos aparatos tecnológicos utilizados(Sauter, 2007).

A evolução do portifólio do grupo alemão $A R T+C O M{ }^{11}$, que mistura produções comerciais e artísticas, é um bom exemplo para se observar as mudanças ocorridas nessas duas décadas. Para Sauter, integrante e fundador do grupo:

Os anos 1990 foram a década das interfaces. Infelizmente, repetidamente projetos foram ovacionados na mídia, curados ou ganharam prêmios apenas por suas tecnologias de interface inovadoras e fascinantes. O conteúdo expressado

\footnotetext{
9 Clara Boj e Diego Díaz definem a Realidade Aumentada (RA) a combinação de elementos interativos reais e virtuais. Em contraste com a Realidade Virtual (RV), na qual o usuário é introduzido em um ambiente completamente imersivo, o que o retira do entorno real, a RA nos permite ver o mundo real a todo o tempo, acrescido com objetos virtuais, que, em situações ideais, aparentam estar presentes fisicamente no espaço. Opostamente à RV, que substitui a realidade, a RA a complementa (Boj; Díaz, 2008, p. 143).

10 Joachim Sauter é mídia-artista e designer desde os anos 1980. Desde o início de sua carreira ele focou na experimentação com as tecnologias digitais e explorando como elas podem ser utilizadas para expressar conteúdos, formas e narrativas. Devido a este interesse, fundou em 1988 a ART+COM, em parceria com outros artistas, designers, cientistas e tecnologistas com interesse comum. Já foi convidado para exibir seus trabalhos em inúmeros lugares: 'Centre Pompidou' Paris, 'Stejdilik Museum' Amsterdam, 'Museum for Contemporary Art' Sidney, 'Deichtorhallen Hamburg', Kunsthalle Wien, 'Venice Biennial', 'ICC' Tokyo, 'Getty Center' Los Angeles, 'ZKM' Karlsruhe) e já foi premiado com inúmeros prêmios, como o 'Ars Electronica Interactive Award', o 'Los Angeles Interactive Media Award', o 'Prix Pixel INA', o 'British Academy for Film and Television Interactive Award'. Desde 1991 é professor titular da cadeira de "New Media Art and Design” na Universidade de Artes de Berlim e desde 2001 é professor adjunto da UCLA, Los Angeles. Página do artista disponível em: http://www.joachimsauter.com, acessado em 20/Março/2009.

11 Site oficial do grupo disponível em http://www.artcom.de, acessado em 27/Jan/2009.
} 
por eles era frequentemente considerado como secundário. Isso mudou essencialmente na atual década: as "novas" mídias amadureceram. Hoje, aplicações, instalações e ambientes interativos são julgados por conta da qualidade de sua concepção e de seu design, da qualidade das experiências que eles provocam, da informação mediada por eles e de sua utilidade.

Sauter, 2008, p.73, tradução nossa ${ }^{12}$

É possível que essa maturidade mencionada por Sauter se dê, sobretudo, pelas constantes experimentações, pelo distanciamento histórico e pelo enriquecimento de repertório, o que permite que a própria comunidade possa refletir, comentar e dialogar com a produção que lhe é contemporânea. É no bojo desse contexto, por exemplo, que surge na área da Arte Eletrônica a disciplina Arqueologia das Mídias, uma aproximação alternativa ao tema das mídias encabeçada pelo teórico alemão Siegfried Zielinski13, autor de diversos livros nesta área.

Diante das atitudes de deslumbramento da comunidade engajada no ramo de Media Art, comuns no fim dos anos 1980 e consolidadas nos anos 1990, Zielinski comenta:

\begin{abstract}
As mudanças, que se tornaram prática padrão, foram julgadas como uma revolução, inteiramente comparada em significância à Revolução Industrial. Aclamada como o início da sociedade da informação e da nova economia, em que as pessoas não mais teriam que ganhar a vida através do suor de suas testas, a proclamada revolução se apoiou inteiramente sob o signo do presente, e admitiu-se que o novo perderia seu terror. Cada último fenômeno digital e
\end{abstract}

\footnotetext{
12 Excerto original em inglês: "The 1990s were the decade of interfaces. Unfortunately, again and again projects were acknowledge in the media, curated, or awarded prices only because of their innovativeand fascinating interfaces technologies. The content conveyed by them was often seen as secondary. This has changed fundamentally in the current decade: The "new" medium has maturated. Today, interactive applications, installations and environments are judged because of the quality of their concept and design, the quality of experiences they evoke, the information mediated by them, and their utility" (Sauter, 2008, p.73).

13 Siegfried Zielinski é responsável pela cadeira de Teoria das Mídias na Universidade de Artes de Berlim e pela cadeira de Ph.D Michel Foucault na EGS (European Graduate School), com foco nas áreas de Arqueologia e Variantologia das Mídias e Tecnocultura. Estudou Artes Cênicas, Literatura Germânica Moderna, Linguística, Semiótica, Sociologia, Filosofia e Ciência Política em Marburg e Berlim, tanto na Universidade Livre como na Universidade Técnica. Já publicou mais de uma dúzia de livros e mais de 150 ensaios, principalmente na área de história e teoria das mídias. Atualmente trabalha na publicação de uma série de 5 volumes intitulada "Variantology - Deep Time Relations of Arts, Sciences and Technologies". Já lecionou e palestrou em inúmeros países e, dentro de suas atuações na Academy of Media Arts Cologne, fundou e dirigiu o festival anual Digitale, em cooperação com Nils Roeller. Em colaboração com Silvia Wagnermaier, fundou o "Vilém Flusser Archive" e suas publicações derivadas. Informações extraídas de: http://www.egs.edu/faculty/zielinski.html, acessado em 25/Março/2009.
} 
rede de informação era celebrado como uma brilhante e dramática inovação. Foi esta audácia ruidosa, encontrada não apenas na refeição diária pela qual a mídia se servia, mas também nas reflexões teóricas, o que me provocou a encarregar-me desta investigação de tamanho escopo.

Zielinski, 2006, p.8, tradução nossa14

O comentário de Zielinski sobre o consumo feroz das novas invenções técnicas na área da Arte Eletrônica é uma das inquietações compartilhadas no escopo desta dissertação. Optamos pelo recorte de leitura após os anos 1990 pois identifica-se sensíveis diferenças na produção ao longo dos quase 20 anos de seu amadurecimento. Notamos que não se trata de mera evolução técnica, considerando desde a popularização dos computadores pessoais no início dos anos 1990 até os atuais experimentos com internet avançada; mas sim da crescente formação de uma cultura digital, que expande potencialmente o acesso e a produção de informação e conhecimento, através da cultura do "faça você mesmo", da colaboratividade, dos ativismos nômades, das experimentações telemáticas, entre outras - e infinitas - atividades.

Não se pode afirmar que a produção dos anos 1990 seja desprovida de conteúdos intrigantes, mas que talvez a produção deste período estivesse mais relacionada a experimentações formais com as novas possibilidades que a popularização da cultura digital começava a oferecer. Caracterizava-se como uma produção ainda sem muitas referências, e que se construía em terrenos desconhecidos pelos poucos artistas e cientistas que se embrenhavam por estas trilhas. Seguem alguns exemplos desta passagem a que nos referimos.

\subsubsection{0 potencial imersivo das CAVEs}

A produção de Media Art dos anos 1990 foi bastante marcada pelos ambientes do tipo CAVE, do inglês Automatic Virtual Environment, os quais se constituem de espaços fechados em forma de cubo para a geração de Realidade Virtual, implementada por meio de amplas projeções estereoscópicas que ocupam dois ou três lados, bem como o piso e o teto do cubo, proporcionando ao observador uma situação altamente imersiva. (Glannetti, 2006).

A citar um exemplo, tomaremos a instalação CAVE “World Skin" realizada

\footnotetext{
14 Do original em inglês: "The shifts, which had became standard practice, were judged to be a revolution, entirely comparable in significance to the Industrial Revolution. Hailed as the beginning of the information society and new economy, where people would no longer have to earn a living by the sweat of their brow, the proclaimed revolution stood wholly under the sign of the present, and it was assumed that the new would lose its terrors. Every last digital phenomenon and data network was celebrated as a brilliant and dramatic innovation. It was this vociferous audacity, found not only in the daily fare served up by the media but also in theoretical refletions, that provoke me to undertake a far-ranging quest"' (Zielinski, 2006, p.8).
} 
em 1997 pelo artista francês Maurice Benayoun15. Em “Word Skin" os visitantes navegam imersos por uma vasta e sombria colagem de paisagens de guerra, munidos com óculos de visualização 3D, um joystick e câmeras fotográficas. Ironicamente, as câmeras fotográficas usadas como interface para a interação são objetos-metáfora. À medida que os visitantes fotografam os soldados e as cenas de guerra, também a aniquilam. Os fragmentos fotografados desaparecem do espaço imagético da CAVE, sendo a ausência explicitada por uma área monocromática com silhuetas escuras. Trata-se de uma proposta de múltiplas metáforas que utiliza aspectos imersivos não pelo mero prazer do visitante, mas para suscitar perturbadoras sensações e reflexões (Grau, 2007).

\section{Figura 1.6: Imagem} de "World Skin" de Maurice Benayoun. Fonte: Benayoun (2007, website).

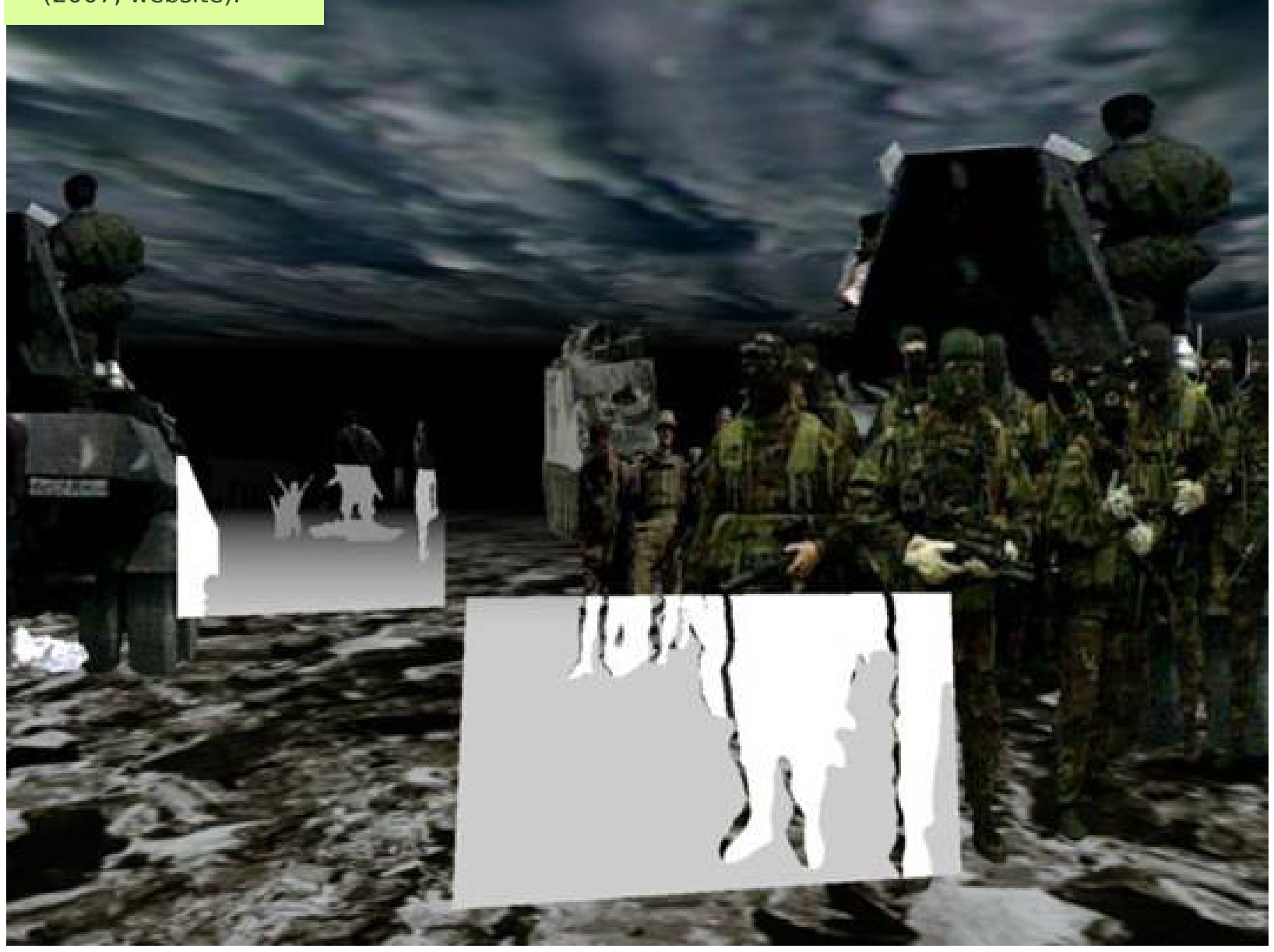

15 Maurice Benayoun é um dos mídia-artistas pioneiros, cujos trabalhos têm sido vistos e honrados no mundo todo. Seu trabalho emprega diferentes mídias, incluindo a combinação delas, tais como vídeo, realidade virtual, web, tecnologia wireless, performance, instalações interativas, em larga escala e no espaço público. Em 1998 foi premiado com o Golden Nica no Ars Electronica na categoria Arte Interativa, pelo seu trabalho "World Skin". Juntamente com “The Tunnel”, este trabalho foi considerado pela crítica como uma autêntica apropriação artística da tecnologia, introduzindo o conceito de situação simbólica. Na busca pelos limites do que se chama de "arquiteturas da comunicação", Benayoun se envolveu em diversas exibições em larga escala, eventos e projetos de arquitetura. "The Navigation Room" (1997) e "The Membrane" (2001) — os quais introduziram o conceito de "design de exibição orgânico" - foram criados para a Cité des Sciences de la Villette. Desde 1984 Benayoun leciona vídeo-arte e Media Art na Université de Paris 1 (Panthéon-Sorbonne). Foi artista-residente na École Nationale Supérieure des Beaux Arts e é co-fundador e diretor artístico do centro de pesquisa CITU (Création Interactive Transdisciplinaire Universitaire) das Universités Paris 1 e Paris 8. Benayoun nos concedeu entrevista em seu escritório e residência em Paris em 10/Jul/2008 
Premiada com o cobiçado Golden Nica na categoria Interactive Art no Ars Electronica 1997 (Grau, 2007, p.277), a instalação “World Skin” tornou-se referência no mundo da Media Art e até hoje é exibida em diferentes lugares, se atualizando a cada montagem.

\subsubsection{Transição para a abertura aos espaços públicos e semi- públicos}

Como exemplo para diferenciar a produção dos anos 2000, tomamos um trabalho em que é possível perceber que o uso artístico das mídias digitais caminha para outra direção. Apesar de apresentar um grande apelo imersivo, pode se dizer que neste trabalho já se iniciam experimentações para a fruição coletiva por um número maior de pessoas, na direção do processamento de dados mais naturalizado no ambiente (computação ubíqua), e da abertura para espaços públicos ou semi-públicos, como no caso do teatro.

Trata-se da criação de palco e figurino interativos criados pelo grupo ART+COM para a ópera "The Jewel of Malta" dirigida por Andre Werner. Apresentada em 2002 na Opera Biennale Munich, a proposta foi a de implementar uma camada reativa e dinâmica de mídias sobre o design tradicional de palco e figurinos, de modo a introduzir uma parte "ativa" à apresentação da ópera.

No palco, projetado especificamente para esta finalidade, grandes planos foram dispostos para que neles fossem projetad os temas gráficos que compunham um cenário animado, como uma espécie de "arquitetura em tempo-real" Com propósito semelhante, o figurino também foi midiaticamente aumentado: através de um sistema de rastreamento de movimento desenvolvido especialmente para esta ópera, máscaras digitais foram geradas em tempo-real e eram projetadas no exato recorte do corpo dos personagens. Assim, através da aplicação de texturas dinâmicas aos seus corpos, foi possível transmitir aos espectadores uma camada extra de significados acerca do estado psicológico dos personagens (Sauter, 2008, p.70).

Segundo Joachim Sauter, embora tenham sido aplicados grandes esforços para a inovação e o desenvolvimento tecnológico da proposta (a produção em tempo real de máscaras nos figurinos foi uma iniciativa pioneira), a exposição da tecnologia jamais foi o principal eixo de suas preocupações. Para ele, o principal objetivo era a criação de novas maneiras de expressão ao diretor da ópera e aos cantores/atores (Sauter, 2008, p.70).

Para evidenciar as diferenças da produção dos anos 1990 em relação aos anos 2000, podemos observar as próprias trajetórias dos artistas e grupos citados. Maurice Benayoun, reconhecido internacionalmente pela CAVE "World Skin" nos anos 1990, tem como um de seus últimos trabalhos um projeto baseado na ressignificação de um monumento da cidade de Paris, o Arco do Triunfo, na direção de uma reflexão de uma arquitetura simbólica, mas que também atua na discussão de espaços públicos (Benayoun, 2008), atual tendência da Media Art. 


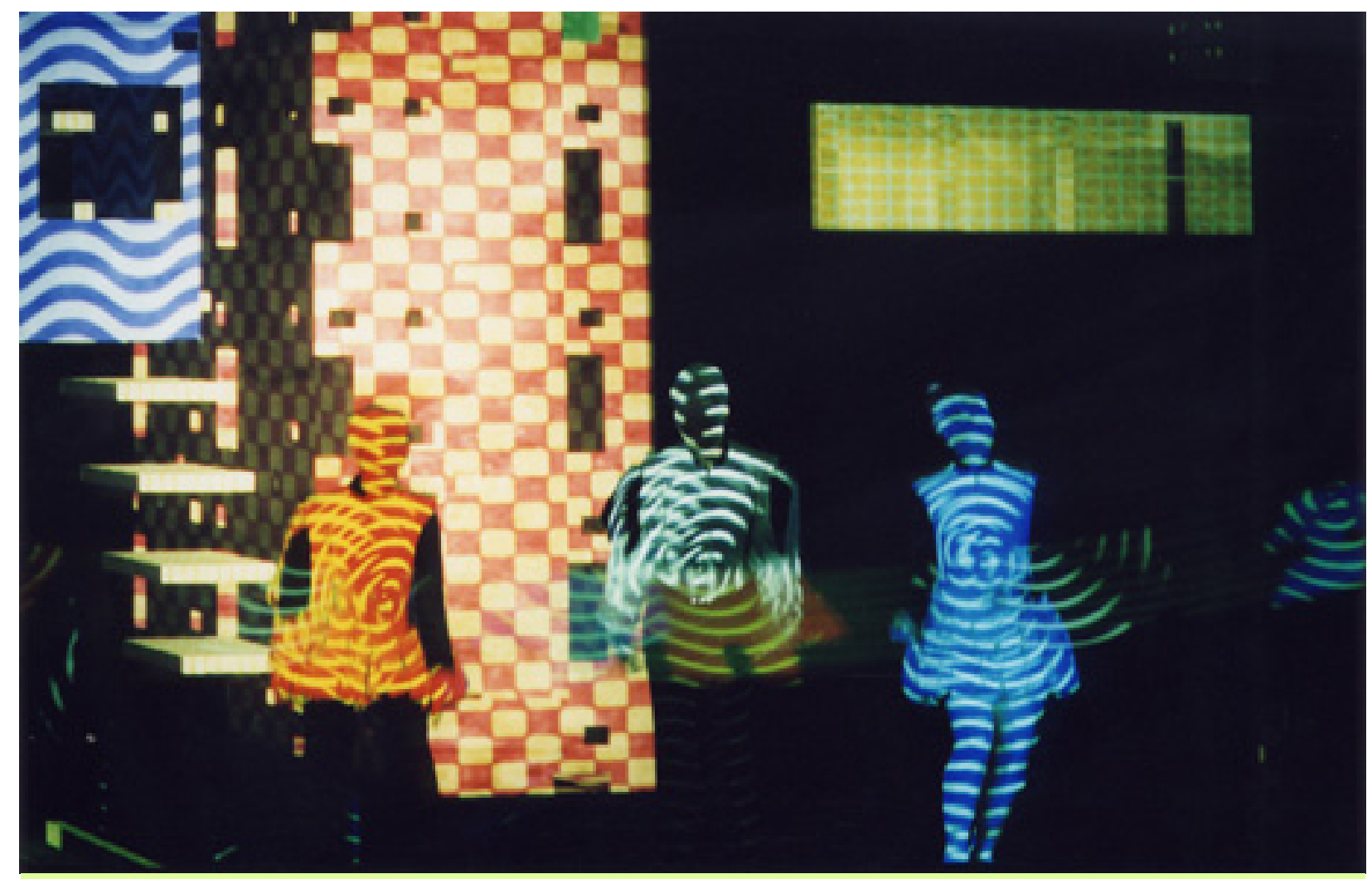

Figuras 1.7 e 1.8: Imagens da ópera "The Jewel of Malta", espetáculo de ópera dirigido por André Werner com a participação do ART+COM. Fonte: ART+COM (2009, website).

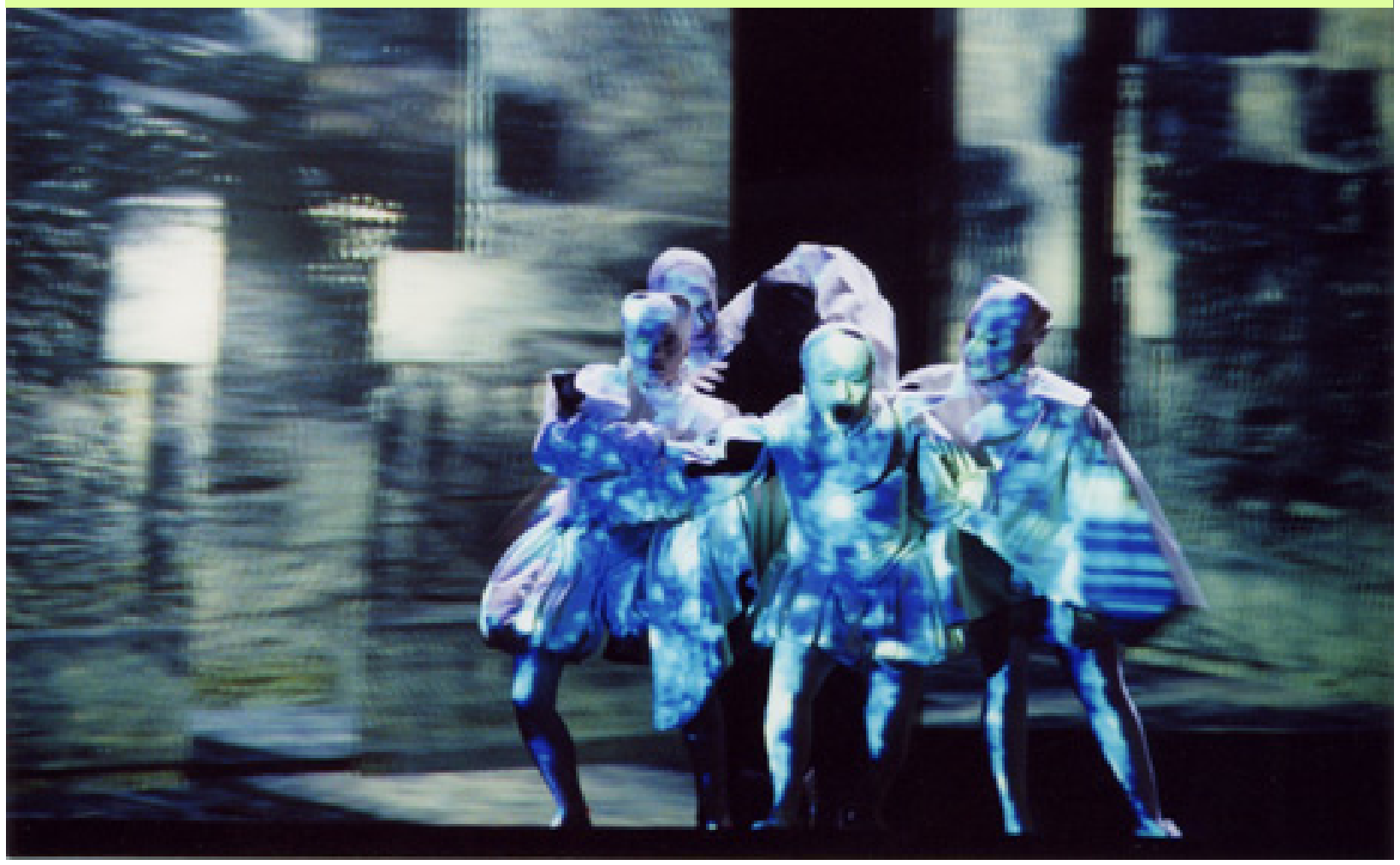

\subsubsection{Tendência ao espaço público}

A tendência de migração da arte contemporânea para espaços públicos (ruas, praças, parques, etc.) e semi-públicos (estações de metrô, shopping centers, etc.) já foi discutida por diferentes teóricos nos anos 1970, a citar Frank Popper, mas curiosamente esta discussão tem sido retomada nos anos 2000 por diferentes teóricos e artistas, como Joachim Sauter, Christiane Paul ou mesmo 
Monika Fleischmann e Wolfgang Strauss.

A caracterização de Paul em relação às manifestações de arte pública pode ser conferida na citação abaixo:

a tão chamada 'arte pública' tem uma longa história, e o termo tem sido tradicionalmente usado para o que é exibido em espaços públicos existentes fora de um designado contexto de arte (neste sentido o museu e a galeria não são espaços públicos); ou para eventos performativos no espaço público (por exemplo trabalhos criados por movimentos artísticos como Fluxus ou Situacionistas).

Paul, 2008, p.163-4, tradução nossa16

A seguir apresentaremos exemplos para ilustrar as duas tendências mencionadas por Paul.

\subsubsection{Interfaces tangíveis no espaço público}

Como exemplo do primeiro tipo de manifestação citado por Paul - o da exibição em espaços fora do contexto tradicional das artes - pode-se citar "Duality", instalação desenvolvida pelo ART+COM em Tóquio entre 2006 e 2007. O objetivo era criar uma instalação interativa que reagisse a sua localidade, acrescentando elementos que ajudassem a construir sua identidade (Sauter, 2008). Assim foi construída uma interface situada entre uma passarela e um espelho d'água. Na passarela foram colocadas placas de leds brancos cobertos com vidro jateado. Nos vidros foram anexados sensores de peso, que mediam exatamente a posição e a força dos passos, os quais acionam ondas virtuais no plano de leds. Quando essas ondas virtuais atingem a fronteira entre a passarela o espelho d'água, são disparadas ondas solenóides por atuadores de alta precisão (Sauter, 2008, p.72).

Avalia-se a proposta de "Duality" como um exemplo bastante criativo de intervenção de Arte Eletrônica no espaço público. Nela, cria-se um diálogo entre virtual e concreto que não age apenas sobre um sistema informacional, mas que se constitui como uma proposição poética que permite múltiplas camadas de interação e o estabelecimento de novas relações dos transeuntes com o espaço pelo qual eles passam.

16 Excerto original: "So-called 'public art' has a long history, and the term has tradicionally been used for art that is displayed in public spaces existing outside of a designated art context (in this sense, the museum and gallery are not a public space); or for performative events in public space (for example works created by art movements such as Fluxus or the Situationists) (Paul, 2008, p.163-4). 
Figura 1.9: Sketch da instalação "Duality". Fonte: ART+COM (2009, website).
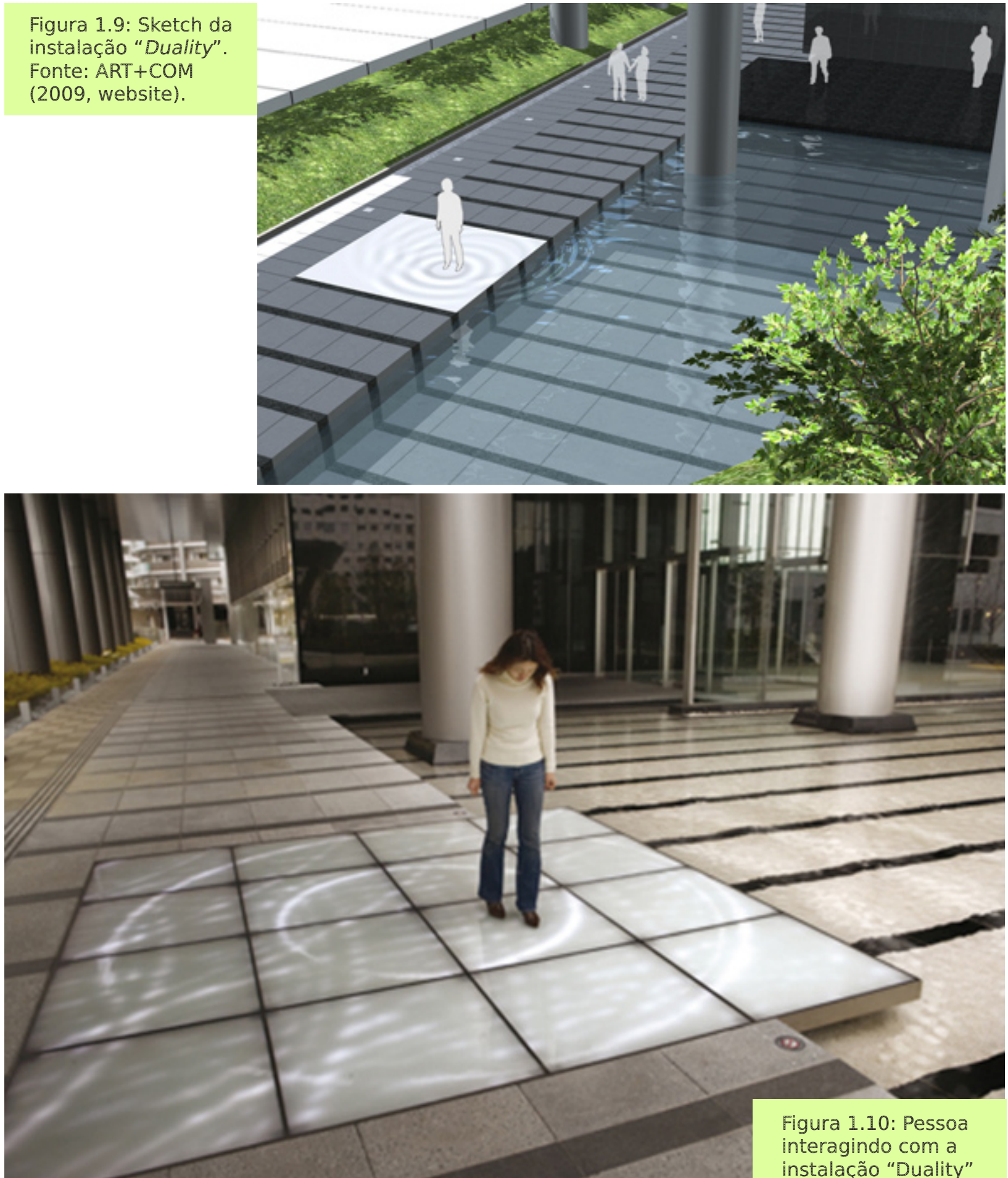
interagindo com a instalação "Duality" (Tóquio, 2007). Fonte: $\mathrm{ART}+\mathrm{COM}$ (2009, website).

\subsubsection{Mídias e performances no espaço público}

Como exemplo do segundo tipo de manifestação artística no espaço público citado por Paul - o de eventos performativos, podemos falar da performance "Perfect Human", elaborada pela dupla de artistas Mika Satomi e Hannah-Perner Wilson 17 apresentada no Ars Electronica Festival 2008. A performer veste uma roupa equipada com dispositivos eletrônicos, tais como 
sensores de dobras estrategicamente colocados nas posições correspondentes às articulações de seu corpo. A cada articulação são atribuídos diferentes fragmentos de textos sobre o corpo perfeito, inspirados no curta-metragem homônimo de Joergen Leth, de 1967 e no filme de Lars von Trier "The Five Obstructions" (2003). Segundo as artistas, o intuito era criar a sexta obstrução, através da introdução do controle sobre a performance e sobre a narração não-linear. A narração, toda fragmentada ganha forma a partir da movimentação da performer, que brinca simultaneamente com o corpo e com o texto. Para que houvesse a mobilidade necessária às condições de espaço público, as artistas trabalharam com tecnologia wireless e de rádio. Era através de rádios de pilha portáteis que o público acessava a estação em que se ouvia o texto manipulado pela performer em tempo-real.

A parte interativa de "Perfect Human" era sugerida pela marcação de um quadrado vazio no chão, localizado à frente da performer. Um interator que ocupasse o quadrado tinha seus gestos e movimentos repetidos pela performer, a qual cedia seu corpo para mediar a manipulação do texto pelo público.

Esta tendência de migração da arte para o espaço público apresenta diferentes especificidades por se situar em contextos históricos e tecnológicos completamente diferentes. Podemos dizer que, em relação ao uso de tecnologias eletrônicas em práticas artísticas, o fortalecimento da concepção de computação ubíqua e de tecnologia correspondentes, como o wi-fi permitiram que as experimentações pudessem avançar com mais preparo, praticidade e segurança para os espaços públicos.

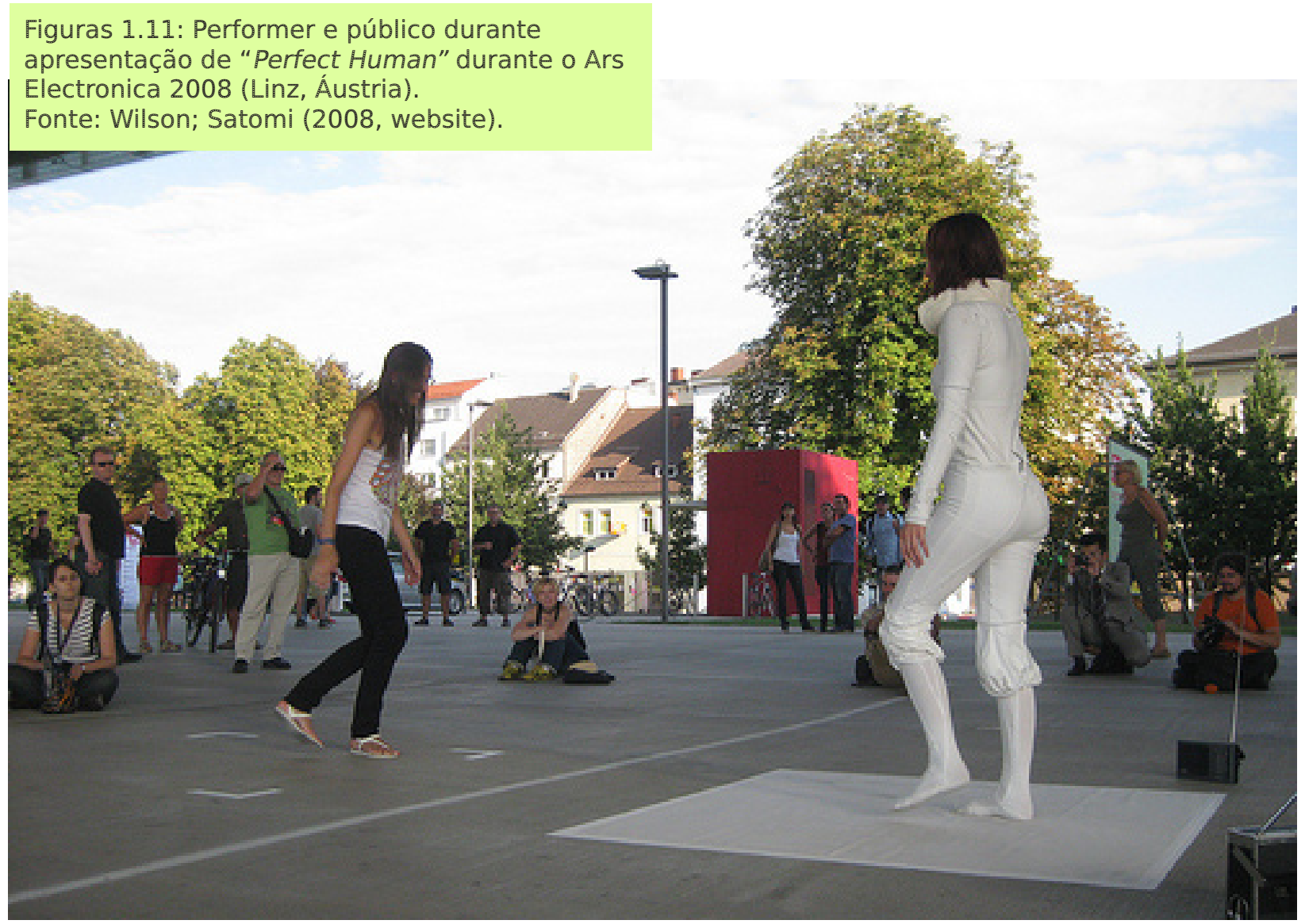

17 Site oficial da dupla de artista disponível em http://kobakant.at. Acessado em 27/Jan/2009. 
A interação proporcionada por trabalhos de Arte Eletrônica em espaços públicos pode ser vista como uma formalização do aspecto comunicacional e cibernético da produção. Por um lado, ao se depararem com as propostas, as pessoas podem ficar surpresas com o aspecto inusitado do que presenciam e continuar suas tarefas cotidianas enquanto transeuntes, podendo mais tarde refletir ou não sobre o que vivenciaram. Por outro, as pessoas podem se ver fisgadas pela curiosidade e se interessarem por diversos aspectos da proposta, tentando entender o que ali está se passando técnica ou esteticamente.

Espaços de exibição... Acho que recentemente existe esse tipo de separação dos cubos brancos, o que eu gosto bastante... quero dizer, não acho que os espaços de exibição devam ser somente cubos brancos. E também não gosto da arte eletrônica acontecendo nas salas escuras. Então eu tento fugir disso... e até o momento, esta é uma das coisas que tenho desenvolvido em meu trabalho, que ele não deve estar num cubo negro ou branco, que possa estar em qualquer lugar. Então eu tento fazê-lo de forma que funcione em outros espaços.

Satomi, 2008, tradução nossa18

A vontade de expressar seu trabalho no espaço público, é confirmado por Mika Satomi durante entrevista realizada com a artista.

O ímpeto de se publicizar o trabalho realizado, tanto em níveis estéticos como em níveis técnicos pode ser constatado também no fato da dupla de artistas Satomi e Wilson disponibilizarem na internet um vasto e detalhado material sobre cada um de seus trabalhos, se apresentando completamente abertas para dúvidas e discussão.

Dentro das comunidades em rede, o espaço público assume inúmeras e diferenciadas formas. Pode-se considerar toda a internet como um espaço público, governado por múltiplos usuários e protocolos, e possibilitando diferentes níveis de acesso. Por outro lado, dentro desse universo, projetos individuais podem propor micro-esferas públicas com suas regras "locais". Como nos espaços públicos físicos, os ambientes criados em rede permitem diferentes tipos de intervenções, desde as manifestações ambientais e políticas (protestos públicos e desobediência civil) até as manifestações estéticas, aos moldes de intervenções e performances artísticas (Paul, 2008, p.174-5).

Para Joachim Sauter do ART+COM, instalações interativas em espaços públicos abertos lidam com condições completamente diversas e implicam em

\footnotetext{
18 Entrevista com Mika Satomi realizada em Linz, Áustria em 1\%/Maio/2008. Excerto original da citação: “Exhibition spaces... I think recently there is this kind of separation from white cubes, which I like a lot... I mean... I don't think that the exhibition spaces should be only white cubes. And also, I don't like the media art being in the dark room. So I try to get away from that and... So far, (I like) that is one of the things (I think) I am developing in my work, that it hasn't to be in the dark or in the white cube, or can be anywhere. Then I try to make the one that can work in other spaces" (Satomi, 2008).
} 
outra natureza de desafios. No caso de exibições de instalações interativas em galerias e museus, apesar de se considerar o público como uma incógnita em relação ao grau de envolvimento que terá com as instalações, ele é, de certa forma, filtrado, selecionado. Há a possibilidade das pessoas irem à exibição munidas de um conhecimento prévio sobre o tema da mostra ou mesmo sobre cada uma das instalações. Já nos espaços públicos, não há filtro algum. Do público especializado ao público iletrado, todos podem se deparar e interagir com a instalação ou performance proposta. Diante disso, a produção de Arte Eletrônica voltada para espaços públicos demanda princípios de interface e de interação adaptáveis a esta situação. Faz-se perspicaz e justo trabalhar com proposições que incluam tanto a reatividade, quando o sistema simplesmente reage aos transeuntes, quanto a interatividade, quando o transeunte percebe incidentalmente o princípio de funcionamento e começa a interagir ativamente com o sistema. Além disso, um desafio também relevante está em como fazer uma instalação durável, sujeita aos intemperismos ambientais e aos atos de vandalismo (Sauter, 2008, p.72-3).

Para mídia-artista e teórico Peter Weibel, apoiados num período histórico eminentemente "maquínico", os espaços públicos - ampliados, móveis e desterritorializados - como as ruas, as praças, os jornais, a tv, o rádio, a internet, entre outros, formam novos fóruns para as articulações artísticas. Eles exercem o papel de um campo de interação para uma arte diferenciada, que dialoga desde com os meros transeuntes até com os mais engajados na cena artística, e que buscam a criação de uma sociedade renovada (Weibel, 2005).

Um dos conceitos a que se refere Weibel é a noção dos processos de produção e fruição da Media Art enquanto um "campo de atuação", algo que, segundo ele, está para além da "obra aberta" proposta e discutida por Umberto Eco. Essa ideia, que não consiste apenas em "instruções lingüísticas" ou “atos performativos", pode incorporar os objetos enquanto agentes para a ação.

Na mesma linha de pensamento, na opinião do casal de artistas Monika Fleischmann e Wolfgang Strauss “as mídias interativas estão apoiando os mecanismos multissensoriais do corpo e, dessa forma, estendendo o espaço para jogo e ação" (Fleischmann; Strauss apud Grau, 2007, p. 253).

Para Weibel, numa mostra de Arte Eletrônica, o comportamento do visitante influencia os arredores e consequentemente a percepção dos outros visitantes. Um visitante tem, a princípio, o mesmo poder de ação que todos os outros. O foco está na atuação individual que repercute no coletivo.

Desdobramentos deste "campo de atuação" individual e coletivo mencionado por Weibel serão explorados no capítulo seguinte, quando discutiremos as relações entre as partes envolvidas nos processos de design da Media Art. A seguir, pinçaremos algumas características da produção de Arte Eletrônica relacionadas à Cibernética de Segunda Ordem, direcionando nosso olhar sobre ela enquanto um sistema estético. 


\subsection{Aspectos de um sistema estético}

Depois de passarmos pelas conexões históricas com os anos 1960 e termos caracterizado a produção contemporânea de Media Art, apresentaremos as relações desta com a ciência Cibernética, cujas teorias nos servem como ferramentas para a análise crítica sobre nosso objeto de pesquisa. Na seqüência, pinçaremos exemplos para ilustrar três aspectos abordados pela Cibernética e que relacionamos com a produção de Arte Eletrônica: (1) a comunicação, (2) as relações entre acidente e programa e (3) a recursividade - ou autopoiesis, nos termos cibernéticos.

O termo "acidente" em nosso contexto é sinônimo de acaso, coincidências, de incursões inesperadas, sem trazer conotação de catástrofe ou de desdobramentos indesejáveis. Da mesma forma, consideramos como sinônimos os termos "programa" e "controle".

\subsubsection{Media Art e Cibernética}

Com imbricações estreitas e inevitáveis, Media Art e Ciência entram juntas em cena num momento que se valoriza o processo e a experiência, e não mais o objeto final da criação artística, estabelecendo entre si ricas relações interdisciplinares. Como exemplos contemporâneos dessas relações, podemos citar recorrentes contaminações de artistas pela ciência e de cientistas pela arte, como são os casos de Christa Sommerer e Laurent Mignonneau, Eduardo Kac, Otto Rössler, entre tantos outros.

\section{Estes artistas internacionalmente proeminentes que frequentemente trabalham como cientistas em institutos de pesquisa estão comprometidos no desenvolvimento de novas interfaces, modelos de interação e códigos inovadores: eles próprios estipulam os limites técnicos de acordo com suas próprias metas e critérios estéticos.}

Grau, 2007, p.5, tradução nossa ${ }^{19}$

Apesar de fortemente baseada nos aspectos técnicos da produção, a produção de Media Art se constrói num contexto que evidencia as qualidades experimentais da arte e os aspectos da recepção, de modo a identificar um continuum entre as estéticas analógica e digital. Essa abordagem implica na discussão da Arte Eletrônica como inserida tanto no campo da Arte como no da Ciência contemporâneas (Broeckmann, 2007, p.194). Nesta direção, sempre questionador e provocativo, Zielinski coloca a pergunta: 
Não precisamos de mais cientistas com olhos aguçados como os de linces e audição acurada como a de gafanhotos, e mais artistas que estejam preparados para correr riscos ao invés de meramente moderar o progresso social utilizando instrumentos estéticos?

Zielinski, 2006, p.11, tradução nossa20

Atentos a estas relações, mergulhamos em observar e experimentar a produção de Arte Eletrônica com base na Cibernética. Para Flusser, embora ele não valide totalmente a definição proposta, a Cibernética é descrita "enquanto arte de pilotar e dirigir um sistema complexo ('caixa-preta') tendo em vista a transformação dos acasos que ocorrem no interior do sistema em situações informativas" (Flusser, 2008, p. 126).

Uma premissa fundamental para se compreender o alcance da proposta da teoria cibernética é considerar que ela marca a passagem do conceito de energia para o conceito de informação como parâmetro elementar da comunicação. Um modelo baseado em teoria da informação, ao contrário da física newtoniana, considera os sistemas como abertos (Giannetti, 2006, p.26).

A ubiqüidade com que a ideia de "informação" se apresenta em nosso cotidiano é fruto das transformações paradigmáticas que enfrentamos desde sempre na história das civilizações, e se intensifica consideravelmente após o surgimento das mídias eletrônicas. O contexto em processo de transformação desde então, deu espaço para o surgimento de correntes teóricas diretamente influenciadas pela Cibernética e pela Teoria da Informação. Tratam-se de correntes teóricas que concebem o parâmetro "informação" como elemento chave para a compreensão de processos estéticos, e que buscam uma alternativa às tendências idealistas, transcendentais ou epistemológicas das teorias estéticas derivadas da tradição kantiano-hegeliana (Giannetti, 2006, p. 16).

Essas correntes teóricas apesar de possuírem precedentes comuns, se diferenciam na maneira de julgar o parâmetro "informação". Por exemplo, ao passo que Max Bense (1957) trabalhava com métodos quantificáveis; Helmar Frank e Herbert Franke propõem o princípio dos modelos sucessivos, ou seja, de "modelos funcionais e práticos aplicáveis à obra para permitir uma aproximação progressiva e por partes - do mais simples ao mais complexo - a sua estrutura" (Giannetti, 2006, p.57). Além disso, em oposição à perspectiva de Bense; Frank e Franke, em consonância com os princípios da Cibernética de Segunda Ordem,

\footnotetext{
20 Do original em inglês: "Don't we need more scientists with eyes as sharp as lynxes and hearing as acute as locusts, and more artists who are prepared to run risks instead of merely moderating social progress by using aesthetic devices?' (Zielinski, 2006, p.11).
} 
consideram a influência dos valores subjetivos no processo estético.

Exemplos emblemáticos do desenvolvimento da Cibernética junto à produção artística podem ser encontrados nas obras do ciberneticista inglês Gordon Pask e seu discípulo, também inglês, Roy Ascott.

Pask (1970) coloca que para se construir um ambiente esteticamente potente são necessários algumas principais qualidades. São elas: (1) o ambiente precisa oferecer variedade suficiente para promover a "potencial novidade controlável" pelo sujeito; (2) ele precisa conter formas que o sujeito possa interpretar, ou aprender a interpretar em vários níveis de abstração, (3) ele precisa fornecer pistas ou instruções declaradas tacitamente para guiar o aprendizado e os processos abstrativos; e (4) ele pode, adicionalmente, responder ao sujeito, envolvendo-o numa conversação e adaptar suas características ao modo de discurso dominante (Pask, 1970, p.76). Tais colocações de Pask estão ligadas à Teoria Conversacional desenvolvida por ele.

Além desses propósitos cabe ressaltar que a Cibernética de Segunda Ordem, em consonância com o princípio fundamental da Endofísica, de se considerar o observador como protagonista na observação do sistema, também aponta na direção de uma Endoestética (Giannetti, 2006).

\subsubsection{Comunicação: interações máquina-máquina, homem- máquina e homem-homem}

Dentro do contexto da produção estética maquínica e cibernética da Arte Eletrônica (Broeckmann, 2007), podemos destacar três principais tipos de fluxos de informação: aqueles que ocorrem entre interações máquina-máquina (M-M), os das interações homem-máquina (H-M) e aqueles das interações homem-homem (H-H) mediadas (ou não) pelas máquinas, e que podem incluir as duas primeiras formas mencionadas. Podemos considerar essas variações tipológicas de comunicação em instalações interativas, como pertencentes ao nível constitutivo da produção da Arte Eletrônica, em suas atividades de criação e fruição.

Para exemplificar a complexidade de relações possíveis que emergem do olhar sistêmico e cibernético sobre uma obra de Arte Eletrônica, retomaremos o exemplo da performance "Perfect Human" citado no item dedicado à tendência da arte contemporânea rumo aos espaços públicos.

A partir da análise da obra de Mika Satomi e Hannah-Perner Wilson, tentaremos deixar mais evidente os sistemas e sub-sistemas participantes das interações M-M, H-M e H-H, que podem ser identificadas em quaisquer obras de Arte Eletrônica. 
Existe um sistema geral formado pelos seguintes elementos arbitrariamente escolhidos por nós na análise: artistas-performer-máquinasinteratores-observadores-momento-lugar. Dentro deste sistema podemos identificar outros sub-sistemas, que surgem de possibilidades combinatórias incontáveis: o sistema dos dispositivos técnicos (sensores, computador e rádios); o sistema artistas; o sistema performer; o sistema artista-dispositivos; o sistema performer-dispositivos; o sistema performer-interator; o sistema artista-interatores; o sistema interatores-dispositivos, e assim por diante.

\section{PERFECT HUMAN PERFORMANCE TECHNICAL SETUP}

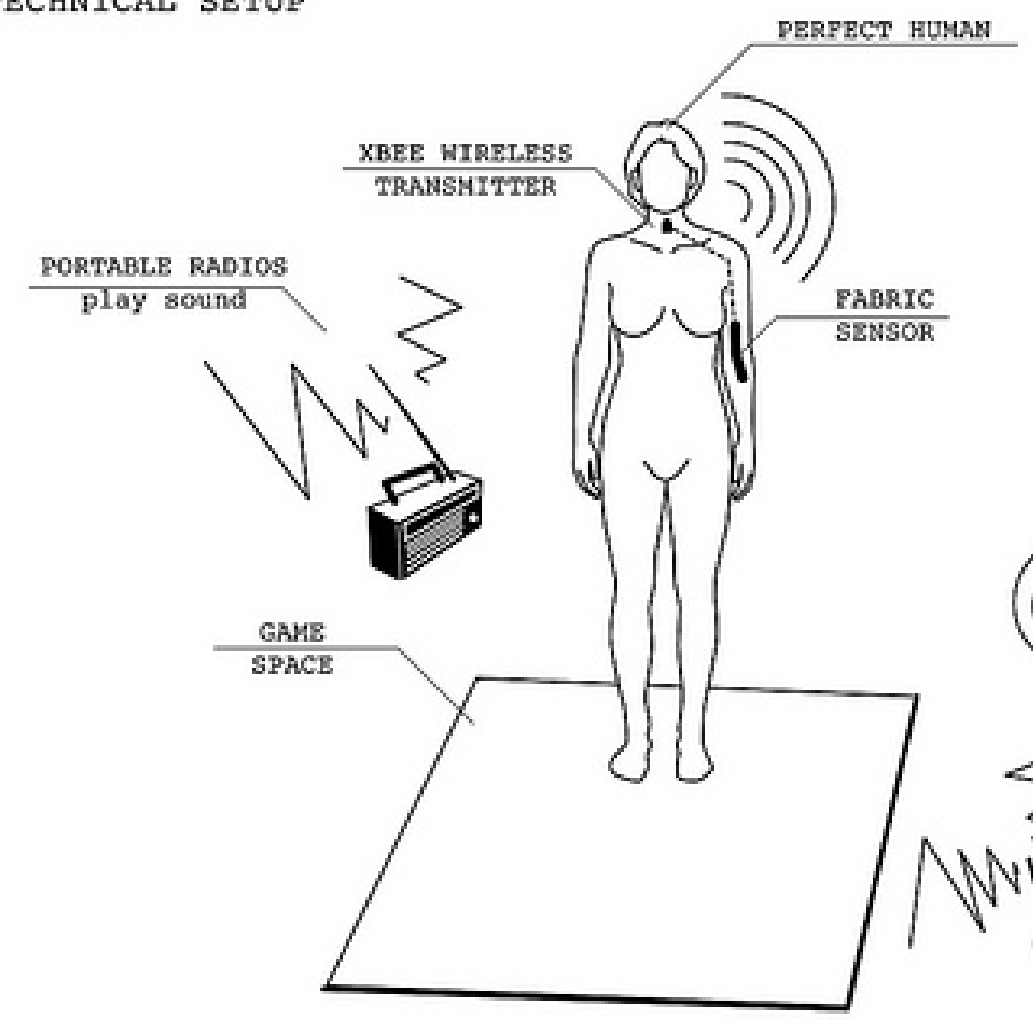

Figura 1.12: Sketch do funcionamento de "Perfect Human", de Mika Satomi e Hannah-Perner Wilson. Fonte: Satomi; Wilson (2008, website).

A comunicação entre os diversos sistemas em comunicação numa proposição de Arte Eletrônica é baseada no tráfego e tradução de dados analógicos e digitais. As experiências estéticas proporcionadas pela Arte Eletrônica são entrelaçadas e articuladas pelas tramas das máquinas, aparatos que são os exoesqueletos de nossas percepções e expressões. No entanto, apesar de apresentar um forte aspecto técnico e maquínico, a Arte Eletrônica é antes de tudo produzida por pessoas, e pode se constituir como uma prática enriquecedora das experiências simultaneamente indivudual e coletiva.

Na perspectiva do filósofo e historiador da cultura alemão Martin Burckhardt, das máquinas como "disposições culturais que articulam e desarticulam a agência humana, construindo relacionamentos e cortando os laços com naturezas e culturas múltiplas" (Burkhardt, 1999 apud Broeckmann, 2007, p.194, tradução nossa21), podemos vislumbrar uma potência transformadora e emancipadora da

\footnotetext{
21 Excerto original: "cultural dispositions that articulate and disarticulate human agency, constructing relationships and cutting ties with multiple natures and multiple cultures.”(Burkhardt, 1999 apud Broeckmann, 2007 apud Grau, , 2007, p.194).
} 
"estética maquínica" da Media Art? Discutiremos a potência e os desdobramentos desta prática nos capítulos 2 e 3.

\subsubsection{Entre o acidente e o programa}

As relações entre acidente e programa envolvem todas as atividades criativas. No caso da Arte Eletrônica, essas duas instâncias são estruturalmente inerentes à maneira de se produzir as chamadas "imagens sintéticas"(Flusser, 2008). Embora seja possível programar comportamentos e experiências a serem sugeridas aos interatores; à medida que tais proposições são confrontadas com sistemas externos ao seu funcionamento (a citar os estímulos do ambiente ou mesmo o comportamento inesperado do interator), elas se abrem inteiramente às ocorrências acidentais, às instâncias do acaso.

Baseado nos princípios da termodinâmica, Flusser afirmou que "todas as coisas surgem por acidente" (2008, p.18) e que no decorrer de uma sucessão de acasos caminhamos rumo à entropia e ao caos. Nestas circunstâncias, para Flusser, a noção de "programa", também associada à ideia de "controle" nos termos cibernéticos, se apresenta como uma resposta humana aos distúrbios e às novidades encontradas no ambiente circundante.

Gordon Pask em "A comment, a case history and a plan"(1968) coloca que o "homem está propenso a procurar novidade no ambiente circundante e, encontrando um nova situação, a aprender como controlá-la“ (Pask, 1968, p. 76, tradução nossa22). Essa premissa cibernética, segundo Pask, aproxima a noção de controle à do desejo de solução de problemas, sendo essas nossas propensões a base da curiosidade humana e da assimilação de conhecimento (Pask, 1968).

Quando Flusser nos explica a produção e o funcionamento das imagens sintéticas, dois principais conceitos são considerados: automação e programa. Para Flusser, o conceito de "automação" "significa rápida computação de coincidências, junção cega e inerte de átomos (e outros elementos) ao sabor do acaso" (Flusser, 2008, p.76). E o conceito de "programa" "significa a automação no instante preciso no qual a coincidência desejada se forma" (Flusser, 2008, p. 76).

Tomando como base essas definições, ao dizermos que no âmbito da Arte Programmata há espaço para a indeterminação, nos referimos essencialmente ao caráter experimental da produção da Media Art. No universo abstrato dos números e dos algoritmos, ao testarmos as inúmeras possibilidades de se programar os efeitos estéticos desejados em software de processamento em tempo real de inputs e outputs, como Max/msp/jitter, Pure 22 Excerto original: "Man is prone to seek novelty in his environment and, having found a novel situation, to learn how to control
it" (Pask, 1968, p. 76). 
Data, VVVV, Processing, entre outros, estamos sujeitos a reações inesperadas e desconhecidas dessas caixas-pretas que manipulamos, as quais também possuem seus limites. O mídia-artista canadense David Rokeby argumenta que o computador nos incita a acreditar que todo controle é possível, mas que "a essência desta ilusão é o fato de que o controle apenas funciona efetivamente dentro do vácuo cuidadosamente construído na ambigüidade do computador" (Rokeby, 2003, apud Glynn, 2008, p.2, tradução nossa23). Rokeby também coloca que, sendo o computador o resultado da fetichização do controle, ele busca trabalhar com o paradigma oposto em suas proposições, ou seja, criando sistemas de controles inexatos. Para Rokeby,

O controle está saturado... Ou talvez seja melhor dizer que temos de aprender a equilibrar o controle, o qual é muito útil em cirurgias ou na condução de veículos, com outros tipos de compromissos com outras coisas e alteridades, que são mais flexíveis do que as relações de controle, em que nos permitimos ser abertos, engajados e dispostos a sermos surpreendidos. Caso contrário, a vida está morta.

Rokeby, 2003, apud Glynn, 2008, p.3, tradução nossa24

As colocações do artista nos ajudam a elucidar a maneira como os conceitos de acaso e programa são constitutivos da produção da Arte Eletrônica. Os mesmos conceitos também são discutidos por Flusser no âmbito da criatividade, assunto que trataremos com mais atenção no capítulo 2 .

\subsubsection{Autopoiesis}

O modelo autopoiético, desenvolvido na Cibernética de Segunda Ordem pelos neurocientistas chilenos Humberto Maturana, Francisco Varela, entre 1974 e 1981, constitui-se como

\footnotetext{
23 Excerto original: "the crux of this ilussion is the fact that the control only functions effectivelly within the carefully constructed ambiguity vacuum of the computer"(Rokeby, 2003, apud Glynn, 2008, p.2).

24 Trecho original: "Control is over-rated... Or perhaps it is better to say that we need to learn to balance control which is very useful in surgery or driving, with other sorts of engagements with other things and otherness that are looser than control relationships where we allow ourselves to be open, engaged and willing to be surprised. Otherwise life is dead" (Rokeby, 2003, apud Glynn, 2008, p.3)
} 
uma classe de sistema mecanicista em que cada membro da classe é um sistema dinâmico definido como uma unidade por relações que o constituem como uma rede de processos de produção de componentes que: (a) participam recursivamente através de suas interações na geração e compreensão da rede de processos de produção de componentes que os produzem, (b)constituem sua rede de processos de produção de componentes como uma unidade no espaço em que eles (os componentes) existem através da compreensão de suas fronteiras.

Maturana, 1974/1981 apud Glanville, 2001, p.15, tradução nossa25

Pertencentes à Cibernética de Segunda Ordem, termos como "autoreferência", "recursividade" e "autopoiesis" realçam a mudança de paradigma instaurada pela cibernética na observação e estudo de sistemas complexos. Tais conceitos se tornam conceitos inevitáveis na teoria cibernética quando a circularidade e a presença do sujeito é considerada na observação de um dado sistema.

A circularidade colocada pela definição de autopoiesis não é exclusiva da Cibernética e encontra precedentes em diferentes circunstâncias da história da civilização, a citar na mitologia a história de Sísifo, ou na filosofia, o "eterno retorno" introduzido pelo filósofo alemão Friedrich Nietzsche (Flusser, 2008). No entanto, vale lembrar que, como coloca o arquiteto ciberneticista inglês Ranulph Glanville, " uma conseqüência básica de uma organização autopoiética é que tudo o que toma parte num sistema é subordinado à realização de sua autopoiesis, de outra forma ele se desintegra" (2001, p. 15, tradução nossa26). Além disso, acrescenta Glanville, "um sistema autopoiético é estável através de sua (dinâmica) habilidade de manter-se refazendo si mesmo de uma outra maneira" (2001, p.15, tradução nossa ${ }^{27}$ ).

No caso de instalações interativas, pelo fato delas apenas se completarem através da contribuição do interator, consideramos que tratam-se de sistemas potencialmente autopoiéticos. Entre inputs e outputs tanto do sistema da instalação quanto do sistema psíquico do interator são estabelecidas relações

\footnotetext{
25 Excerto original: "a class of mechanistic system in which each member of the class is a dynamic system defined as a unity by relations that constitute it as a network of process of production of components which: (a)recursively participate through their interactions in the generation and realization of the network of processes of production of components which produce them; and (b)constitute this network of processes of production of components as a unit in the space in which they (the components) exist by realizing its boundaries" (Glanville, 2001, p.15).

26 Excerto original: "the basic consequence of the autopoietic organization is that everuthing that takes place in an autopoietic system is subordinated to the realization of its autopoiesis, otherwise it deisntegrates" (Glanville, 2001, p.15).

27 Trecho original: “An autopoietic system is stable through its (dynamic) ability to keep on making itself anew” (Glanville, 2001, p.15).
} 
circulares de comunicação que tendem a se autonomizar. Ainda no campo da Media Art, além da autopoiesis se apresentar no nível constitutivo de uma instalação interativa, ela também pode se evidenciar no âmbito das relações que se tecem entre os participantes de seu processo criativo, assunto abordado no capítulo dois de nosso trabalho.

Um exemplo emblemático da história da Media Art a abordar a recursividade é a obra do artista norte-americano Dan Graham28, intitulada "Present Continuos Past(s)" (1974) (figura1.13). Nesta proposta Graham trabalha com a ideia da continuidade espaço-temporal. Os espelhos refletem o tempo presente, a câmera de vídeo grava o que imediatamente aparece diante dela e a reflexão completa na parede oposta espelhada. A imagem vista pela câmera (refletindo tudo na sala) aparece oito segundos depois num monitor de vídeo (via delay da fita colocada entre dois gravadores de vídeo, um que está gravando, e outro que está reproduzindo a gravação anterior). Uma pessoa que assiste ao monitor, vê simultaneamente a imagem de si no espelho oito segundos antes ao momento presente e a imagem de si no monitor refletida no espelho, que corresponde a 16 segundos antes do momento presente. Se o corpo do observador não está em frente a lente da câmera atrás do espelho, esta grava a reflexão da sala e as imagens refletidas no monitor (que mostra os 85 gravados anteriormente e refletidos pelo espelho). Cria-se uma regressão infinita de tempo continuums dentro de tempo continuums (sempre separado por intervalos de 8 segundos) (Hall, Fiffer, 1990, p. 186).

O espelho situado nos ângulos retos com a parede do monitor e a outra parede-espelho dá o ponto de vista do tempo presente da instalação, como um ponto de vista objetivo e exterior ao ponto de vista da experiência subjetiva do observador e ao mecanismo de funcionamento da instalação que produz o efeito perceptivo da continuidade espaço-temporal.

O efeito de mediar tecnologicamente a auto-percepção através de uma câmera é particularmente poderoso em situações espaciais que incluem o observador. Em proposta dialógica à de Graham, o artista norte-americano Bruce Nauman criou em "Live-Taped Video Corridor"(1969-1970) contrariedade e incômodo a partir da experiência de espaço e tempo causada pelo sentimento de presença ou ausência física. Nauman em sua obra enfatiza especificamente a dependência das impressões físicas na percepção do tempo. Em contraste, Graham tematiza o tempo como uma dimensão que pode ser experimentada no espaço. Com a instalação "Present Continuous Past(s)" ele trata a relação entre a experiência espacial e a experiência temporal. A percepção geralmente tem lugar no presente e Graham inquieta o "observador" através

28 Nascido em 1942 em Urbana, Illinois (EUA), Dan Graham foi um dos pioneiros em performance e vídeo-arte nos anos 1970. Mais tarde focou sua atenção para projetos arquitetônicos projetados para a interação social em espaços públicos. A escrita também se constituiu como um dos fortes aspectos de seu trabalho. Seus textos cobrem assuntos desde peças de arte conceitual inseridas em revistas de cultura de massa, até escritos para amigos artistas próximos e análise da cultura popular. Atualmente mora e trabalha em Nova Iorque. (Medien Kunst Netz) 


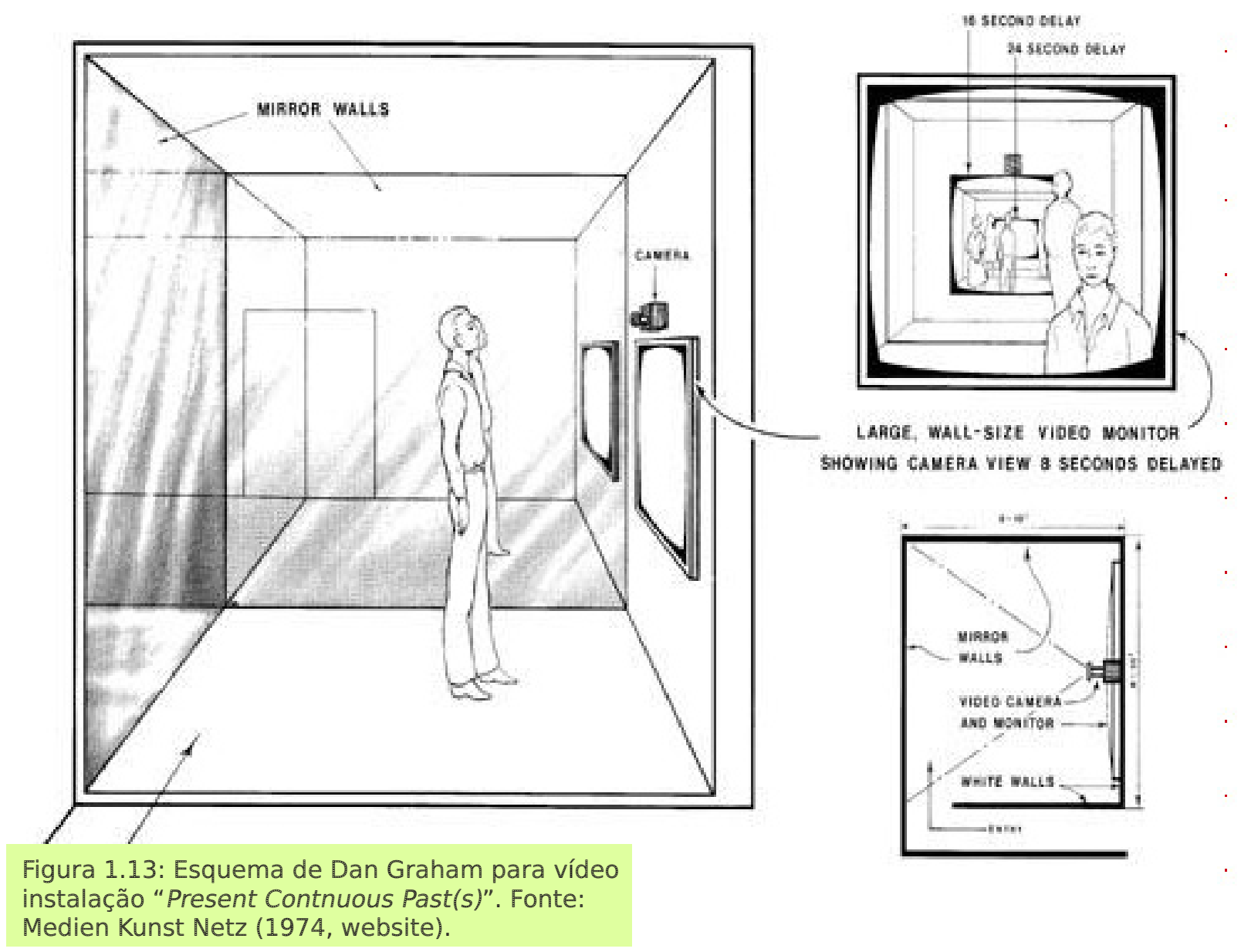

da construção de um espaço que refaz e disponibiliza o fenômeno da presença contínua constantemente disponível para se experimentar, pela visualização da distancia temporal no espaço.

\subsubsection{Nossa experiência sob o olhar cibernético: Don't Give Up! About a history that doesn't want to be told}

Neste item exemplificaremos as relações entre acidente e programa, a recursividade e a comunicação no âmbito constitutivo da instalação interativa "Don't give up! About a history that doesn't want to be told", realizada por nós durante a experiência enquanto pesquisadora do Interface Culture Department da Kunstuniversität Linz, na Áustria, com estreia no Ars Electronica 2008 e remontagem no FILE 2009 - Festival Internacional de Linguagem Eletrônica.

Vista dentro do processo de pesquisa como uma forma de coleta de dados sobre o universo estudado, a instalação constituiu-se como um experimento em que pudemos vivenciar implicações dos aspectos teóricos abordados em nossa pesquisa. Como nosso objetivo aqui não é a mera descrição do funcionamento da instalação, colocamos a seguir algumas imagens para ilustrar a nossa crítica, mas para maiores detalhes do funcionamento da obra, convém consultar o DVD que disponibilizamos junto aos anexos (Anexo B). 


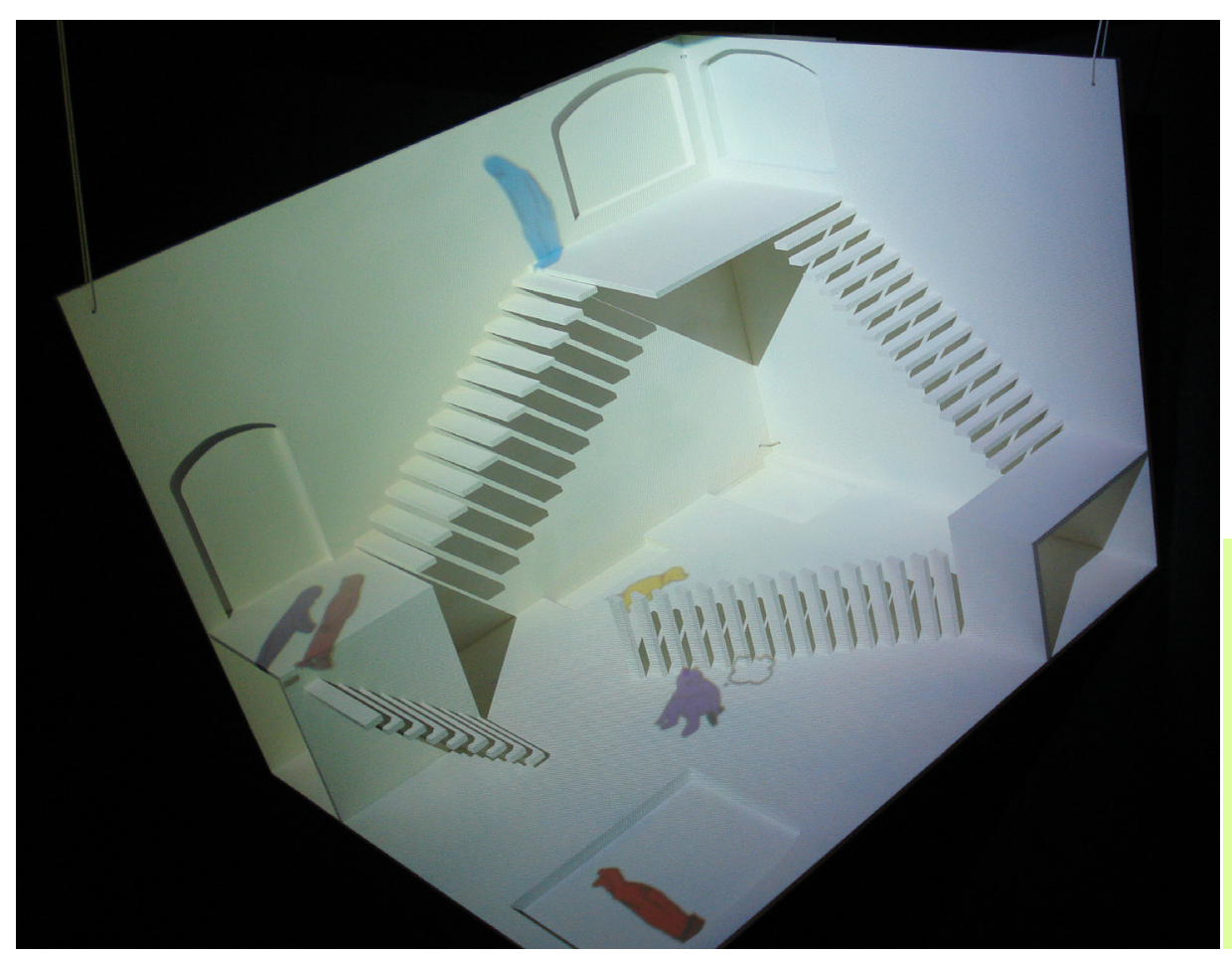

Figura 1.14: Maquete na qual se projetavam simultaneamente as quatro animações, as quais eram controladas pelos interatores através das cordas. Fonte: Lautenschlaeger (2008).

Podemos dizer que as ocorrências mais significativas de acidentes e da abertura ao acaso aconteceram durante os processos de criação e de execução, em que tivemos que nos adaptar as condições existentes. No âmbito constitutivo da instalação, podemos dizer que o funcionamento da instalação foi programado de modo a responder aos estímulos do visitante praticamente sem abertura alguma. Depois do primeiro contato com a interface, o interator compreendia que o seu controle sobre as histórias era limitado e seu engajamento dependeria de seu interesse e ambição emocional e mental em desvendar as relações entre os personagens da história toda que se passa naquele cenário.

Nossa percepção sobre esse ponto se deu por termos recebido respostas variadas como descrições da experiência. Por um lado disseram "uma sensação inusitada e surpreendente no início e que logo se torna enfadonha"29; e por outro "precisa paciência, cuidado e tempo para compreender a obra"30 ou ainda, "é bacana brincar bastante para ver o que todos os personagens são capazes de fazer, ou se há interações entre eles, ou se cada um é independente da trama do outro. (...) se a história muda ou permanece a mesma"31. Retomando Flusser, que entende programar como eleger o acaso desejável entre uma série de acasos, no caso de "Don't Give Up!", talvez os acidentes estejam mais suscetíveis de acontecer no interior das máquinas e das cabeças, ao processarem as informações sugeridas.

Já em relação à recursividade, pudemos experimentá-la em diferentes níveis de intensidade. Tematicamente identificamos um aspecto recursivo:

\footnotetext{
29 Frase extraída do questionário respondido por Joelson G. dos Santos.

30 Frase extraída do questionário respondido por Cláudia Lévy.

31 Frase extraída do questionário respondido por Naila Maui Fukimoto.
} 


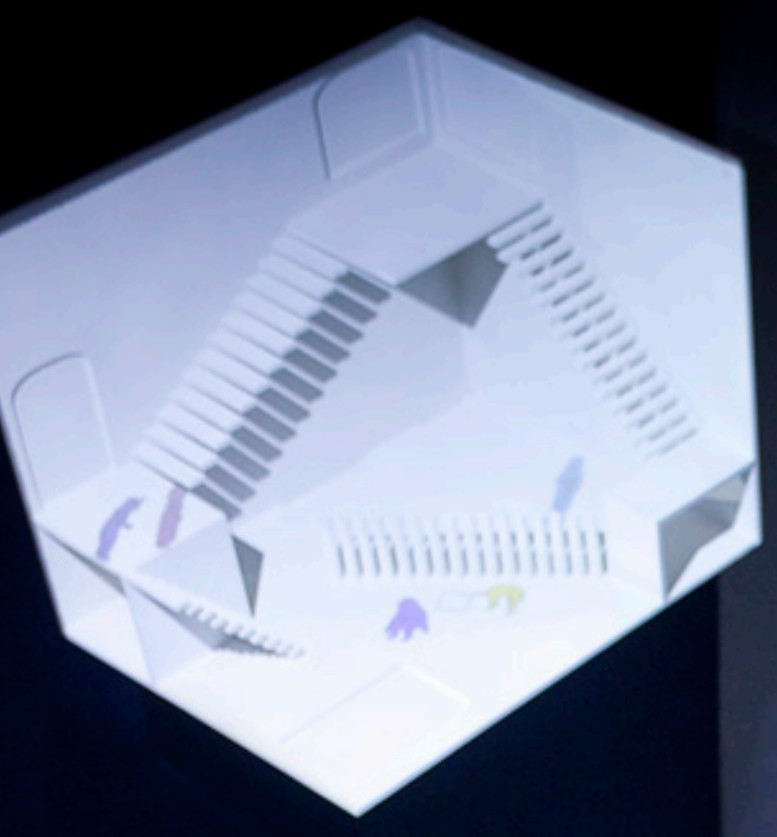


a tensão entre interator e sistema (narrativa) coincide com a situação da pesquisadora e o objeto de pesquisa. O processo investigativo da atividade de pesquisa é metaforicamente colocado no título e na dinâmica de funcionamento da instalação.

No momento de interação e fruição estética, a recursividade está presente em diferentes circunstâncias. As cordas apresentam as histórias em loop eterno, e o desenvolvimento das narrativas só se concretiza a partir da contribuição do interator. O interator, ao manipular as eternas linhas do tempo das histórias projetadas sobre a maquete, completa a circularidade do sistema obra-interator.

Visualizamos essas relações conforme o esquema a seguir (figura 1.16). Evidenciando a comunicação circular, cada vez que a informação muda de natureza após atravessar um sistema complexo, as setas mudam de cor:

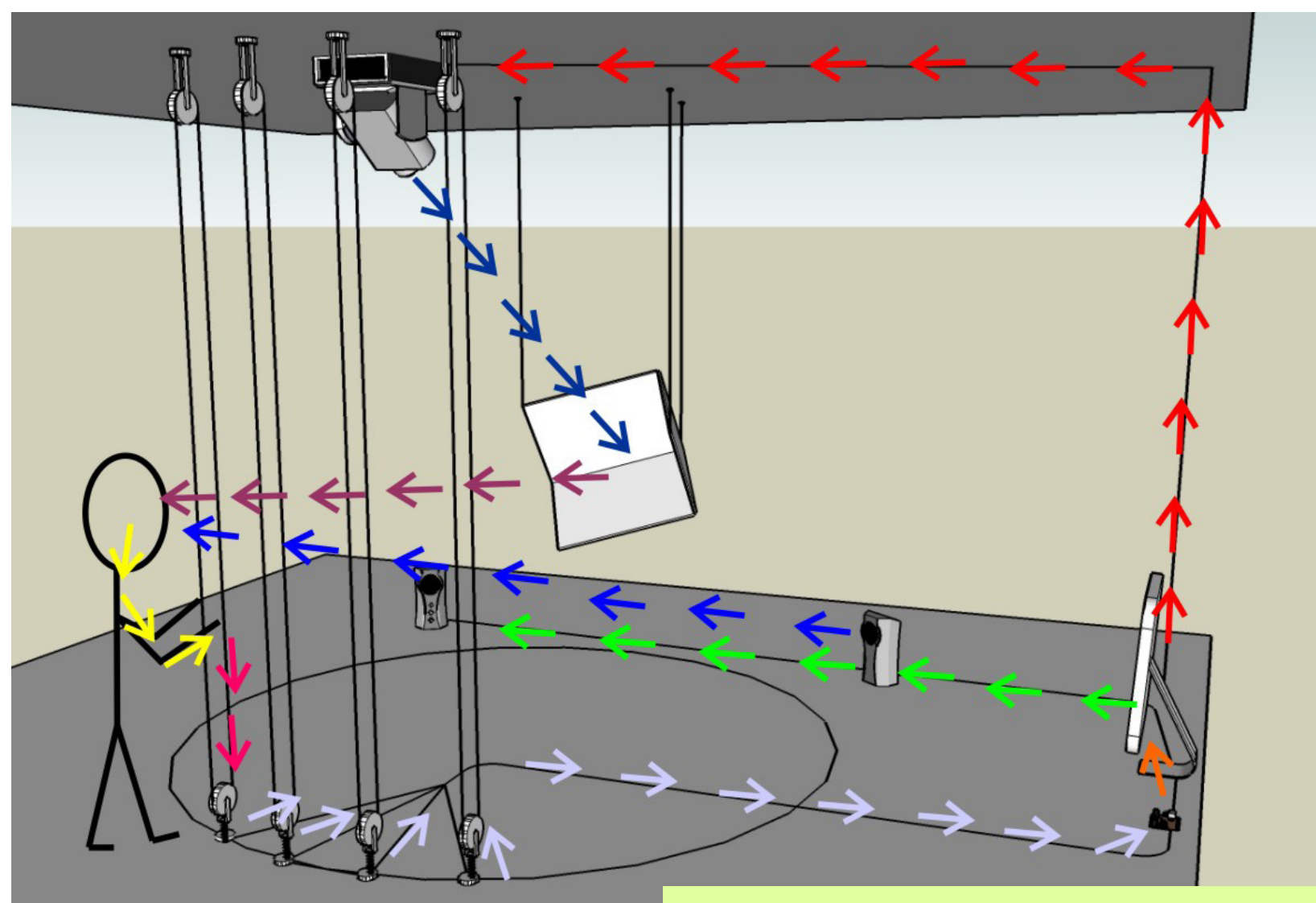

Figura 1.16: Esquema de fluxo de informação entre os sub-sistemas do funcionamento da instalação Don't Give Up! Modelagem 3D: Fábio Abreu Queiroz Fonte: Lautenschlaeger (2009).

Além disso, a corda azul, referente ao homem azul é um ponto especial de recursão. Assim como o interator, este personagem possui uma corda nas mãos e vaga pelo cenário em busca algo.

Em relação à interação e comunicação entre obra e público, reconhecemos que a intenção de recursividade está lá, mas ela não se concretiza via realimentação positiva, àquela que amplifica o desvio e obriga o sistema a se adaptar ao contexto. Neste caso, a recursividade não é a mesma de um 
sistema "vivo", que possui a capacidade de modificar sua estrutura básica para adaptar-se a situações ao acaso provocadas pelo meio (Laurentiz, 2006). Assim, podemos dizer que a circularidade presente na experiência interativa com “Don't Give Up!" corresponde àquela da Cibernética de Primeira Ordem e não à de Segunda Ordem, cujo conceito de autopoiesis lida com a incorporação e a adaptação de distúrbios inseridos ao acaso por sistemas externos.

A recursividade da interação poderia se intensificar se duas condições fossem implementadas nesta instalação. Primeiro, se as animações não fossem vídeos prontos, mas se os interatores atuassem a partir de personagens "livres" para agir como bem entendessem. Segundo, se a relatividade espacial não fosse estática em sua tridimensionalidade, mas se o espaço pudesse ser também manipulado, como por exemplo é possível em "levelHead: A 3D Spatial Memory Game", do artista neozeolandês Julian Oliver, obra indicada como referência por diferentes interlocutores durante o processo de criação da instalação.

Através da análise dasinterlocu ções realizadas durante o processo criativo de "Don't Give Up!", podemos identificar outra instância de circularidade, reservada para discutirmos no capítulo 2.

\subsection{Considerações}

Neste capítulo procuramos circunscrever as características constitutivas do nosso objeto de análise, atravessando desde as instâncias históricas até a caracterização de aspectos estéticos da Arte Eletrônica sob o olhar da Cibernética de Segunda Ordem.

No capítulo 2 estenderemos nossa discussão para o âmbito do processo de criação e execução, caracterizando suas especificidades e explorando como se tecem as relações entre as diferentes partes produtivas. Para a construção de nosso raciocínio nos aprofundaremos um pouco mais na Cibernética de Segunda Ordem, tentando demonstrar a pertinência do uso desta teoria para uma compreensão amadurecida acerca da produção contemporânea de Arte Eletrônica. 


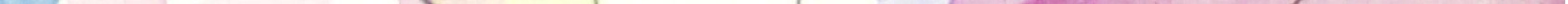




\subsection{A relevância da Cibernética de Segunda Ordem na compreensão da produção de Media Art}

\subsubsection{Cibernética: história, conceitos e contexto}

\section{Cibernética de Primeira Ordem}

Estudo do controle e da comunicação nos animais e nas máquinas.

A Cibernética é a ciência que estuda os princípios abstratos da organização em sistemas complexos. Preocupa-se não tanto com em que consistem os sistemas, mas como eles funcionam. A Cibernética se concentra em como os sistemas utilizam a informação, modelam e controlam as ações no sentido de orientar e manter seus objetivos, ao mesmo tempo em que neutralizam vários distúrbios.

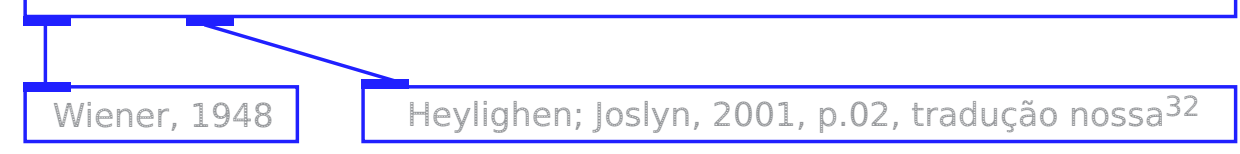

\section{Cibernética de Segunda Ordem}

A Cibernética de Segunda Ordem (...) foi desenvolvida entre 1968 e 1975 em reconhecimento do poder e das conseqüências do exame Cibernética da circularidade. É a Cibernética quando esta está sujeita à crítica e aos entendimentos da Cibernética. É a Cibernética em que o papel do observador é apreciado e reconhecido mais do que dissimulado como se tinha tornado tradicional na ciência ocidental: e é desse modo a Cibernética que considera observando (sistemas) mais do que sistemas observados.

Glanville, 2001, p.03, tradução nossa 33

\footnotetext{
32 Trecho original: "Cybernetics is the science that studies the abstract principles of organization in complex systems. It is concerned not so much with what systems consist of, but how they function. Cybernetics focuses on how systems use information, models, and control actions to steer towards and maintain their goals, while counteracting various disturbances" (Heylighen, Joslyn, 2001, p.02).

33 Excerto original: "Second order Cybernetics (...) was developed between 1968 and 1975 in recognition of the power and consequences of Cybernetic examination of circularity. It is Cibernetics, when Cybernetics is subjected to the critique and the understandings of Cibernetics. It is the Cibernetics in which the role of the observer is appreciated and acknowledged rather than than disguised as had become traditional in western science: and is thus the Cybernetics that considers observing, rather than observed systems" (Glanville, 2001, p.03).
} 
A ciência Cibernética emergiu em meados dos anos 1940 a partir de encontros interdisciplinares entre cientistas e humanistas de varias áreas de conhecimento do período pós-guerra, tais como Norbert Wiener, John von Neumann, Warren McCullogh, Claude Shannon, Heinz von Foester, W. Ross Ashby, Gregory Bateson e Margaret Mead. Desses encontros, conhecidos como "Macy Conferences on Cybernetics" e cujo foco de interesse estava em máquinas e animais, os estudos cibernéticos se ampliaram para uma gama numerosa de assuntos e ideias, entre a mente e os sistemas sociais (Heylighen, Joslyn, 2001).

Desde os anos 1960, dando continuidade à exploração dos estudos dos sistemas complexos e adaptativos, a Cibernética tem atravessado uma ampliação conceitual e ganha vida através de sua aplicação em diferentes áreas do conhecimento: Ciências Sociais, Economia, Política, Matemática e Computação, Psicologia, Design, entre outros.

Por um lado, essa ubiqüidade da Cibernética ao se espalhar por diferentes campos do saber foi vista positivamente por Heinz von Foerster, que a comparou a uma dança: "um processo contínuo em que todos nós existimos em mudança e através de interação, onde nos encontramos refletidos no outro" (Glanville, 2001 , p. 26, tradução nossa ${ }^{34}$ ). De outro lado, em relação às atuais condições e ao futuro da Cibernética, o arquiteto Ciberneticista e professor inglês Ranulph Glanville alerta para o modismo encontrado no uso banal e esvaziado de significado do prefixo -cyber, e aponta para a necessidade de prolongar o desenvolvimento da teoria por si mesma, e não apenas perifericamente pelas outras áreas do saber (Glanville, 2001, p. 26).

Em relação à incorporação da Cibernética em nosso trabalho, tentamos evitar o esvaziamento citado por Glanville, e nos interessam os princípios da Cibernética de Segunda Ordem, por esta, além de considerar o observador durante a ação de se observar os sistemas, analisa a circularidade, a interdependência e autonomia da relação entre "observador" e "observado".

Apesar de a Teoria Cibernética demandar um olhar sobre suas proposições como um todo, para fins didáticos e acadêmicos, como no capítulo anterior, nosso tema toca em duas principais características: a comunicação, a recursividade e as relações entre acidente e programa.

O mapa conceitual ao lado (figura 2.1), desenvolvido pelo cientista da computação especialista em interação usuário-computador Peter Solderitsch, engloba o desenvolvimento e as influências da Cibernética, e pode nos auxiliar a ilustrar as partes que nos interessam na teoria.

Destacada pela cor azul no diagrama, a definição de Cibernética de Solderitsch (ciência observadora de sistemas criados por observadores que constroem modelos a fim de ampliar o entendimento dos próprios sistemas) é a base de nossa metodologia e de nosso argumento. Como participantes do

34 Excerto original: "a continuing process in which we all exist in change and through interaction, where we find ourselves reflected in the other" (Glanville, 2001, p.26). 


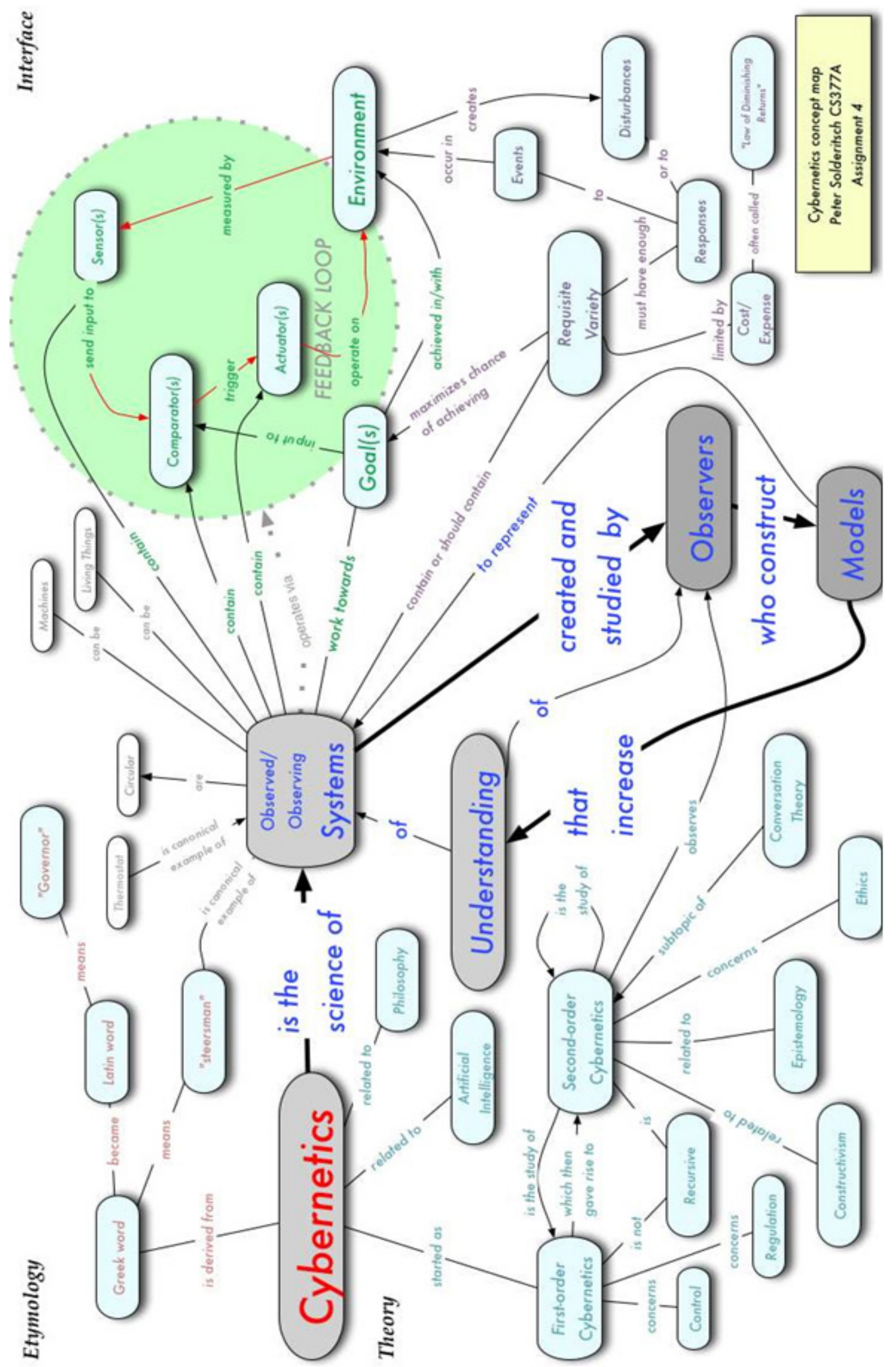

Figura 2.1: Mapa conceitual da Cibernética. Fonte: Solderitsch (2003, website). 
modelo construído, incluímos em nossa análise a experiência que tivemos no universo criativo da Media Art, através da construção da instalação interativa "Don't Give Up! About a history that doesn't want to be told" (Anexo B).

No diagrama apresentado, em relação à Cibernética de Segunda Ordem (em verde no canto inferior esquerdo), Solderitsch a define como recursiva, ou como "observadora do observador", e pode ser relacionada ao Construtivismo, à Epistemologia, à Ética e à Teoria Conversacional. Dentre essas conexões, além da recursividade e da atenção atribuída ao papel desempenhado pelo "observador", nos interessa a Teoria Conversacional, encabeçada por Gordon Pask.

Feitas essas considerações sobre nosso recorte em relação ao uso da Cibernética, com base em argumentos teóricos e práticos, descreveremos neste capítulo como a atividade de produção da Arte Eletrônica enquanto uma Arte potencialmente Cibernética, se baseia em ações colaborativas e se concretiza por meio de trocas entre profissionais de diferentes especialidades, que juntos se debruçam em ações criativas imaginadas. Segundo Flusser, a tendência simultânea de especialização e colaboração é uma forma da sociedade assumir a existência das caixas-pretas que manipulam e, ao mesmo tempo, é uma proposição de como é possível lidar com nossa atual situação cultural (Flusser, 2008).

Além dos aspectos de ousadia e sensibilidade solicitados aos artistas e cientistas na contemporaneidade, a colaboratividade entre profissionais especialistas de diferentes áreas do conhecimento tem se apresentado como um fator essencial para uma atuação enriquecida e criativa nas áreas da Arte e da Ciência. Instigados por este motivo, nos interessamos pelos diálogos que se tecem entre as partes produtivas da produção contemporânea de Arte Eletrônica.

Em "Universo das Imagens sintéticas: elogio da superficialidade" Vilém Flusser incorpora a definição de Cibernética em relação à produção de imagens sintéticas da contemporaneidade, afirmando que esse modelo de relação entre homem e mundo implica na superação da política e da ética, tornando as instituições despidas de ideologia. Segundo o autor, a sociedade das imagens sintéticas faz emergir uma nova espécie de homem, uma espécie pós-histórica, mais cerebral emancipada das necessidades animais, e capaz de vivenciar o conjunto da informação, da libido e da estética de forma "puras" (Flusser, 2008, p. 128). Apoiando-se em Nietzsche, que dizia ser a arte melhor que a verdade, Flusser propõe que a espécie humana está caminhando para atingir uma condição em que os processos cerebrais e as abstrações teóricas se constituem enquanto vivências libidinosas.

Em consonância com o principal argumento de Flusser nesta obra, a atualidade da Cibernética de Segunda Ordem está em observar o movimento e as relações entre as partes do sistema analisado, enfatizando as responsabilidades 
que temos sobre nossas ações no processo criativo. Frente ao aprofundamento da ciência ao nível cada vez mais diminuto e à zero-dimensionalidade, Flusser fala do elogio da superficialidade como que nos apresentando a realidade em que ainda podemos agir, o campo das relações.

Mesmo valorizando o poder dessas relações, nos inquietam as incertezas sobre os possíveis problemas que criamos e criaremos nas relações da sociedade pós-histórica colocada por Flusser. Para onde são transferidos os valores que desenvolvemos em nossa fase histórica? Se ainda não conseguimos responder pronta e plenamente às perguntas que nos colocamos, podemos ao menos tecer os fios que podem nos ajudar a chegar perto de respondê-las.

\subsubsection{Arte como Sistema Social}

As transformações radicais instauradas pelas tecnologias digitais e de telecomunicação, contribuiu para o crescimento da influência dos meios de comunicação e de suas "realidades" sobre as sociedades, em detrimento das visões subjetivas (Giannetti, 2006). Tal condição dá abertura para a proposição do sociólogo ciberneticista alemão Niklas Luhmann sobre o papel da comunicação na sociedade: "a sociedade não está formada por pessoas, mas por comunicações" (Giannetti, 2006, p.63).

Para Luhmann, através do abandono à visão organicista em que prevalecia o protagonismo do sujeito na relação parte-todo, a comunicação passa a ser compreendida como um processo recursivo e auto-regulador entre sistemas, cujo funcionamento depende do funcionamento de cada parte. Essa dependência mútua das partes faz com que a efetividade da comunicação seja bastante improvável (Giannetti, 2006, p.63). Para Luhmann

é improvável que alguém compreenda o que o outro quer dizer, tendo em conta o isolamento e a individualização de sua consciência. O sentido só se pode entender em função do contexto e, para cara um o contexto é, basicamente, o que a sua memória Ihe faculta.

Luhmann, 1992, apud Giannetti, 2006, p.63

No seio desta perspectiva, Luhmann(2000) entende a arte como um sistema social e estético atuante entre o sistema psíquico e o sistema comunicacional, dois sistemas distintos que se relacionam mútua e circularmente. 
Comparada à consciência, a comunicação executa uma seqüência de transformações de signos extremamente lenta e consumidora de tempo (o que o que significa, entre outras coisas, que a consciência participante ganha tempo para a sua própria percepção, imaginação, e trens de pensamento). Comunicação recursivamente chama de volta e antecipa comunicações mais distantes, e exclusivamente no âmbito da rede da auto-criada comunicação ela pode produzir comunicações como os elementos operativos de seu próprio sistema. Ao fazê-lo, a comunicação gera um sistema autopoiético distinto, no estrito (não apenas metafórico) senso do termo. E, dada a forma em que ela organiza sua própria autopoiesis, a comunicação não pode receber ou produzir percepções, mas pode certamente comunicar sobre percepções.

Luhmann, 2000, p.9-10, tradução nossa35

Apesar da polemicidade das proposições de Luhmann, nosso interesse em sua sociologia sistêmica sobre a arte se baseia na interlocução dele com nossos outros autores - Heinz von Foester em "Understanding Understanding" responde a Luhmann com artigo intitulado: "How recusive is Communication" - e no fato dela nos apontar outra perspectiva para melhor compreender a complexidade das relações entre artista, obra e público, em nossa atual situação cultural e no contexto do desenvolvimento de projetos de Arte Eletrônica.

Neste contexto, nos perguntamos se, sendo a Arte um sistema social que antecipa aspectos de desdobramentos de processos históricos, seria a prática da Arte Eletrônica uma das trajetórias possíveis para a concretização de formas inovadoras de Comunicação, a favor da valorização de estruturas horizontais e não-hierárquicas de produção e troca do conhecimento?

Tudo indicaria que sim se não fosse nossa tendência natural rumo à entropia, à massificação e à homogeneidade.

\footnotetext{
35 Trecho original: "Communication can no longer be understood as a 'transmission' of information from an (operatively closed) living being or conscious system to any other such system. Communication is an independent type of formation in the medium of meaning (sinn), an emergent reality that presupposes living beings capable of consciousness but irreducible to any one of these beings, not even to all of them taken together. Compared to consciousness, communication executes an extremely slow, time-consuming sequence os sign transformations (which means, among other things, that the participating consciousness gains time for its own perceptions, imaginations, and trains of thought). Communication recursively recalls and anticipates further communications, and solely within the network of self-created communication can it produce communications as the operative elements of its own system. In so doing, communication generates a distinct autopoietic system in the strict (not just 'metaphorical') sense of the term. And, given the form in which it organizes its own autopoiesis, communication cannot receive or produce perceptions. But it can certainly communicate about perceptions" (Luhmann, 2000, p.9-10, tradução nossa).
} 
Conforme aumenta a entropia, o universo, e todos os sistemas fechados do universo, tendem naturalmente a se deteriorar e a perder a nitidez, a passar de um estado de mínima a outro de máxima probabilidade; de um estado de organização e diferenciação, em que existem formas e distinções, a um estado de caos e mesmice. (...) enquanto o universo como um todo, se de fato existe um universo íntegro, tende a deteriorar-se, existem enclaves locais cuja direção parece ser o oposto à do universo em geral e nos quais há uma tendência limitada e temporária ao incremento da organização.

Wiener, 1954, p.14

Com base na teoria entrópica dos princípios da termodinâmica e na Cibernética, Flusser coloca que a comunicação é um processo intersubjetivo, anti-natural e negativamente entrópico. Um processo que vai contra o movimento geral da natureza rumo à entropia e ao caos. Pensar os processos criativos da Media Art como processos comunicacionais e sociais é uma forma de visualizá-la como uma agente anti-redundância e anti-desinformação (Giannetti, 2006).

Além disso, trazer a Cibernética para entender a Arte enquanto sistema social se fundamenta no argumento de que a Arte também pode ser analisada sob a ótica das manifestações locais (micro) e globais (macro), as quais atendem respectivamente aos movimentos opostos e simultâneos de organização e caos, acidente e programa.

Essa concepção nos influencia a discutir inclusive a noção de criatividade na era da cultura digital: uma criatividade coletiva, calcada na emergência de inovação a partir do jogo de forças entre as esferas micro e macro. Este é o assunto que discutiremos nos itens a seguir.

\subsection{A criatividade na era digital}

\subsubsection{Criatividade e autoria coletivas}

A etimologia da palavra "autor" acusa relações deste termo com a ideia de "autoridade" (Flusser, 2008).

Quando Walter Benjamin(1993) no clássico artigo "A obra de arte na era de sua reprodutibilidade técnica", afirmou que, a partir do surgimento da fotografia a obra de arte perde sua 'aura', ele denunciava o potencial da cópia em, ao tornar abundante, também tornar supérfluo e redundante. Mas 
a pergunta que não se cala é: o que o ato de copiar torna redundante? Talvez a reprodutibilidade técnica torna redundante o esforço humano em repetir informações já produzidas? Neste mesmo movimento a reprodução tende a eliminar o mito e a função de autoridade, esvaziando o conceito "autor" (Flusser, 2008).

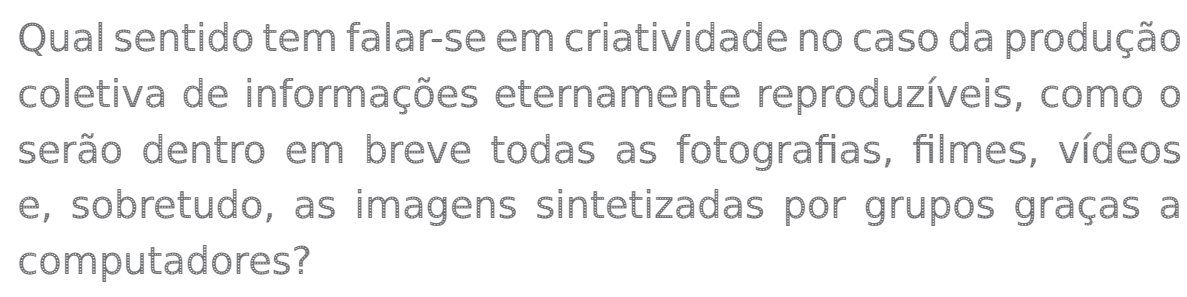

Flusser, 2008, p.101

A partir das mídias digitais, que lidam com o processamento e entrecruzamento de dados em tempo real (e portanto vão bastante além da possibilidade de reprodução), a concepção tradicional de autoria se dissolve em manifestações coletivas de criação. O autor mítico nietzscheano que se inspira e cria na solidão da geleira agora divide espaço com o autor contemporâneo, que se prepara, se programa e cria através do diálogo com outras pessoas, seus co-autores (Flusser, 2008).

Essa perspectiva já é partilhada por diversos pesquisadores das áreas de comunicação, artes e design, a citar os pesquisadores Katerina Alexiou e Theodore Zamenopoulos:

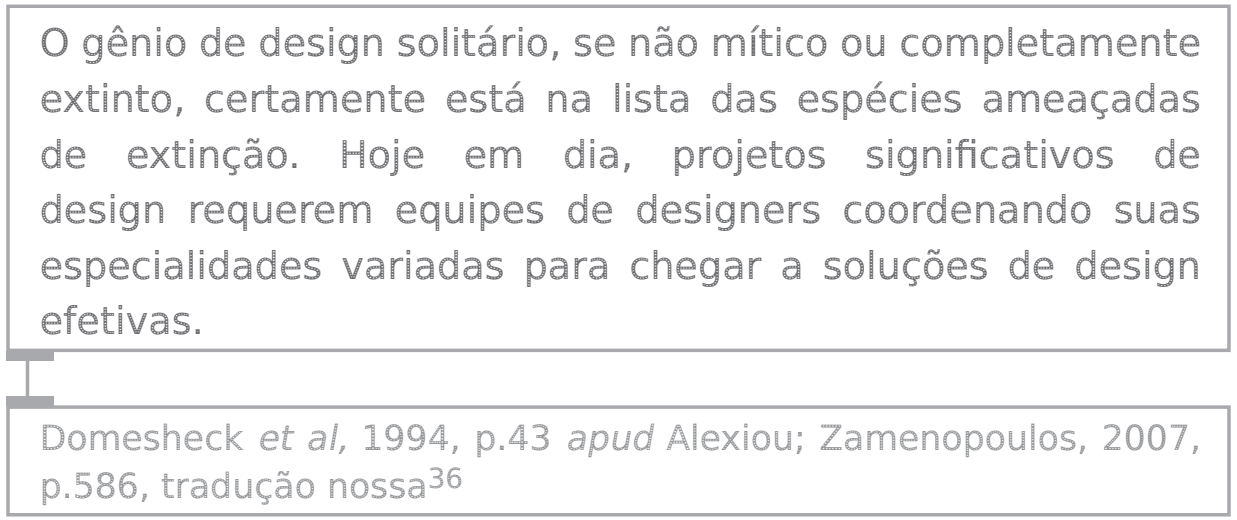

Frente à enorme quantidade de dados e informações que lidamos diariamente, e que definitivamente não somos mais capazes de processar em memórias individuais, por mais geniais que estas possam ser, somos obrigados a nos reinventar. A insuficiência de nossas memórias individuais nos direciona

36 Excerto original: "The lone design genious, if not mithcal or completely extinct, is surely on the endangered species list. Nowadays, significant design projects require teams of designers coordinating their varied expertise to arrive at effective design solutions" (Domesheck et al, 1994, p.43 apud Alexiou; Zamenopoulos, 2007, p.586). 
para as práticas coletivas e distribuídas. Neste contexto, também a criatividade é afetada, nos obrigando a reformular radicalmente nosso conceito sobre ela, na direção de uma criatividade coletiva (Flusser, 2008).

A criatividade coletiva se baseia na geração de informação nova a partir do processamento distribuído de dados. A memória humana tornou-se demasiada lenta e o diálogo interno do artista ou criador solitário se torna inoperante, não se aplica mais. E assim são criados grupos de memórias individuais assistidos por memórias artificiais, tais como laboratórios, comitês, grupos de pesquisa e realização (Flusser, 2008, p. 104). Somente no bojo dessas condições de nossa situação cultural que se formam grupos de artistas engajados na produção da Media Art.

O historiador e teórico norte-americano Bill Nichols (2003), estendendo as ideias do texto clássico de Walter Benjamin sobre a cultura na era da reprodutibilidade técnica para o contexto da cultura eletrônico-digital, afirma que a comunicação através dos meios computacionais simula, e altera nossa relação com nosso meio ambiente e com nossa própria mente. Na era digital, também sob a ótica da Cibernética, coloca o autor:

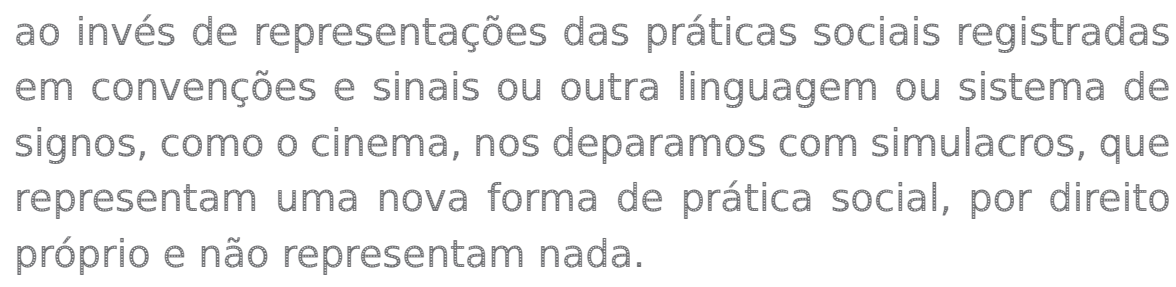
em convenções e sinais ou outra linguagem ou sistema de signos, como o cinema, nos deparamos com simulacros, que representam uma nova forma de prática social, por direito próprio e não representam nada.

Nichols, 2003, p. 631, tradução nossa ${ }^{37}$

O fato de "não representar nada" colocado por Nichols neste excerto é a chave para a compreensão do que Flusser afirma sobre o elogio da superficialidade. Se por trás das abstrações computacionais das imagens técnicas nos confrontamos com o nada, devemos então voltar nossa atenção para a superfície, para o nível das relações e da comunicação, o nível do mundo onde temos a possibilidade de interferir e criar (Flusser, 2008).

Os processos criativos da Media Art, em suas experimentações na combinação e recombinação de objetos e dispositivos técnicos a fim de comunicar a partir da experiência, se constituem como um espaço em potencial para a emergência da comunicação e do conhecimento entre as pessoas envolvidas no cenário.

\footnotetext{
37 Excerto original: "Instead of a representation of social practices recorded into the conventions and signs o another language or sign-system, like the cinema, we encounter simulacra that represent a new form of social practice in their own right and represent nothing" (Nichols, 2003, p. 631)
} 
Artistas, arquitetos e designers estão cada vez mais investigando o uso criativo de tecnologias de sensoriamento, computação e atuação de baixo custo. Com o enorme crescimento de iniciativas em código aberto e de comunidades online, os uma vez difíceis obstáculos de base financeira e de conhecimento têm diminuído consideravelmente.

Glynn, 2008, p.1, tradução nossa ${ }^{38}$

Com o desenvolvimento e a cada vez maior popularização das mídias eletrônico-digitais, os centros e laboratórios de Media Art já nasceram sob a égide de outro paradigma de comunicação que não aquele baseado nos meios de comunicação de massa, com hierarquias pré-estabelecidas; mas sim num paradigma de estruturas horizontais de criação, baseado em conversações. A curadora norte-americana Christiane Paul aponta para a antecipação dos artistas na proposição prática desta mudança de paradigma na comunicação e na criatividade potencialmente inaugurada a partir da cultura eletrônicodigital.

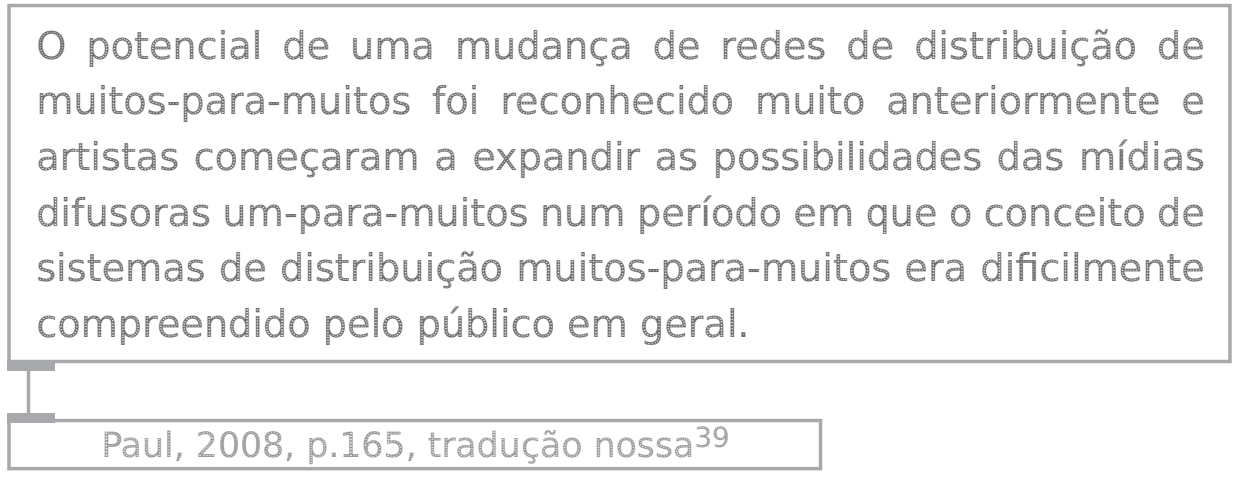

Em concordância com Paul, consideramos que a produção de Media Art com suas especificidades - enquanto arte-processo e que conta com a participação do usuário para se concretizar - pode ser uma das possibilidades de se colocar em prática um paradigma de comunicação e criatividade pautado em conversações.

Para o teórico francês Maurice Blanchot, autor de "Conversações infinitas" (1969), a concepção de Conversação (em contraposição ao monólogo da autoridade ditatorial) se baseia no fato dela própria se fragmentar através da troca de protagonistas, com uma interrupção necessária para a compreensão. Compreensão que dê subsídios para que o sujeito possa também se encorajar para falar.

\footnotetext{
39 Excerto original: "The potential of a shift to many-to-many distribution networks was recognized much earlier and artists had started to expand the possibilities of the one-to-many broadcasting media at a time when the concept of many-to-many distribution systems was hardly recognized by the public in general' (Paul, 2008, p.165).
} 
A manifestação prática dessas conversações da criatividade coletiva, pode ser exemplificada pelo projeto Creative Commons, premiado com o Golden Nica Net Vision do Prix Ars Electronica 2004. Criado sobre a atual necessidade de revisão das políticas de direito autoral, o Creative Commons trata-se de um conjunto de licenças padronizadas para gestão aberta, livre e compartilhada de conteúdos e informação.

Licenças Creative Commons buscam permitir a padronização de declarações de vontade no que diz respeito ao licenciamento e distribuição de conteúdos culturais em geral (textos, músicas, imagens, filmes e outros), de modo a facilitar compartilhamento e recombinação.

Artistas envolvidos com Media Art se envolvem em projetos nessa direção. É um processo criativo que comparamos ao modelo do jogo de xadrez de Flusser, em que o desafio trata-se de extrair das situações o máximo de suas virtualidades, usufruindo dos acasos das situações imprevistas nas estratégias para retirar o máximo de “informação nova”(Flusser, 2008, p. 105). Esta postura prevê uma estratégia diferenciada: transformar adversários em parceiros e polêmicas em diálogos. A criatividade se constitui portanto como uma produção dialógica de informação eternamente reproduzível e eternamente memorável (Flusser, 2008, p.107)

Por outro lado, nossa responsabilidade com a crítica nos permite desconfiar da aparente facilidade de implementação de nossas proposições. Sabemos das Inúmeras adversidades que trafegam pelos mais diversos âmbitos (inclusive político e econômico) e dificultam as vias para se colocar em prática essa concepção ideologicamente mais ética e "democrática" de comunicação. No entanto, consideramos que os pormenores desse problema nos conduziria para uma outra discussão, fora do escopo de nosso trabalho.

\subsubsection{Media Art e a Teoria Conversacional: criação como processo de comunicação}

Grande parte da produção do cibernético inglês Gordon Pask foi dedicada ao desenvolvimento de sua Teoria Conversacional, cuja principal ideia é a de que a aprendizagem se efetive por meio de conversas sobre um assunto ao se tornar um dado conhecimento explícito. Com base nessa teoria, vislumbramos que a prática colaborativa da Media Art também possa ser observada pela ótica de processos comunicacionais, em que os sujeitos envolvidos saiam naturalmente de suas experiências com algo aprendido.

Nossa ênfase na discussão da comunicação no âmbito da Media Art se relaciona com a crítica sobre o que chamou Glanville de "inflação terminológica" da interatividade. Segundo o autor, o termo interatividade tornou-se um chavão 
usado para se referir às tecnologias que fornecem alguma forma de "reação" a uma "entrada do usuário". Essas manifestações realizam truques, mas não nos fornecem nada que seja remota e verdadeiramente interativo, nem há qualquer participação significativa, elas apenas são respostas a determinado estímulo (Glynn, 2008).

Para Glanville, "interação" significa "receptividade mútua que pode levar à novidade, em que nenhum participante tem controle formal sobre o processo. Interação ocorre entre os participantes, não por causa de nenhum deles" (Glanville, 2001, p. 3, tradução nossa ${ }^{40}$ ). Em contraponto, "conversação" corresponde à "interação em andamento", sendo descrita pelo autor como

\begin{tabular}{l} 
uma forma circular de comunicação em que cada \\
participante constrói seu próprio entendimento. Os controles \\
de entendimentos entre participantes ocorrem através da \\
re-presentação de entendimentos individuais em retorno \\
contínuo. Conversação ocorre entre participantes e é \\
essencialmente interativa \\
Glanville, 2001, p. 2, tradução nossa 41 \\
\hline
\end{tabular}

Assim, além de autopoiéticos, consideramos os processos conversacionais como ampliadamente aplicáveis a quaisquer tipos de discursos, verbais e não-verbais. Segundo a escritora e editora de periódicos relevantes na área de Arte Contemporânea Monika Szewczyk42(2009), em ensaio publicado na E-flux, a definição mais simples de um tipo mais simples de conversação é baseada na interlocução fragmentada de discursos. Quando duas pessoas se falam, elas não falam juntas, mas cada uma na sua vez. Alguém diz uma coisa depois pára, e a outra pessoa diz outra coisa, depois pára. O discurso coerente que elas conduzem é composto de seqüências que são interrompidas quando a conversação move de um colaborador a outro, mesmo que sejam feitas adaptações de modo a que eles correspondem a um outro. $O$ fato de que 0 discurso precisa passar de um interlocutor a outro a fim de ser confirmado, contrariado, ou desenvolvido mostra a necessidade do intervalo.

Para Blanchot (1969), a fala e o silêncio, como duas formas de interrupção, podem servir como compreensão dialética ou podem produzir algo de natureza mais complexa. Tudo depende de como concebemos os interlocutores na

\footnotetext{
40 Excerto original: "Mutual responsiveness that may lead to novelty, in which no participant has formal control over the proceedings. Interaction occurs between participants, not because of any of them" (Glanville, 2001, p. 3).

41 Trecho original: "A circular form of communication in which each participant constructs his own understanding. Checks on understandings between participants occur through re-presentation of individual understandings in a feedback loop. Conversation Occurs between participants and is essentially interactive" (q.v.) (Glanville, 2001, p.2)

42 Monika Szewczyk é escritora e editora sediada em Berlim e Roterdã, onde coordena as publicações no Witte de With, centro de Arte Contemporânea e é tutora no Piet Zwart Institute. Ela também atua como colaboradora da revista Prior, em Ghent. Disponível em http://www.e-flux.com/journal/view/37, acesso em 02/Fevereiro/2009.
} 
conversa. Se virmos nosso interlocutor como um oposto, quer como objeto de nosso discurso subjetivo, ou como um sujeito que é infinitamente diferente, mas igual a nós, entramos numa dialética que busca síntese e unidade: compreensão. Por outro lado, se assumimos nosso interlocutor não como um oposto, mas como um neutro - uma alteridade que detém em nome do neutro - a conversação vai além da relação binária que estrutura a dialética (Blanchot, 1969).

Concebendo o diálogo para além da dialética (que detém a unidade e a síntese como um fim), podemos nos aproximar do infinito que se prolifera através da implantação do neutro. Isto quer dizer que um tipo de geometria de pensamento está em jogo que poderá permitir o próprio pensamento mover por si mesmo completamente diferente

Szewczyk, 2009, p.2-3, tradução nossa ${ }^{43}$

Com base nestas colocações, podemos concluir que a conversação é por definição circular, não é mensagem transmitida, codificada, é o que o participante faz dela. A conversação pode também ser reflexiva, quando ela tem como tema si própria.

Criticando a situação contemporânea, Flusser afirma que os diálogos telematizados não são conversações, são conversas fiadas. Para ele,

\begin{tabular}{l} 
todos recebem imediatamente um número colossal \\
de informações, mas todos recebem o mesmo tipo de \\
informação, não importa onde estejam. Ora, nessa situação \\
todo diálogo se torna redundante. Já que todos disporão de \\
informações idênticas, nada haverá a ser autenticamente \\
dialogado. \\
\hline Flusser, 2008, p. 87 \\
\hline
\end{tabular}

E, para exemplificar sua colocação, Flusser cita a exposição Electra em 1984 em Paris, definindo a atmosfera do evento como "tolice generalizada". Segundo ele, a mostra não se propunha a diálogos inteligentes; apenas a apresentação de novos gadgets que substituiriam o filme, o livro, o telefone e o correio (Flusser, 2008, p. 86).

Mesmo considerando a mudança substancial da produção de Media Art entre anos 1990 e 2000, como apontamos através da opinião de Joachim Sauter no capítulo 1; no âmbito social em geral o tempo passou e muitas pessoas

\footnotetext{
43 Excerto original: "Conceiving of dialogue beyond dialectics (which holds out unity and synthesis as an end), we can approach the infinity that proliferates via its deployment of the neutral. This is to say that a kind of geometry of thought is at stake that might allow for thought itself to move differently altogether" (Szewczyk, 2009, p.2-3).
} 
ainda não perceberam que a potência não se encontra nos dispositivos trazidos pela revolução da era digital, mas sobretudo nos diálogos que se tecem entre as pessoas numa situação cultural outra, e que atravessa uma metamorfose da percepção (Santos, 2003). Com base na comunicação que se tece entre os colaboradores é que, por exemplo Roy Ascott fundamentou a proposta de uma "Cybernetic Art Matrix" ou mesmo que Flusser propõe a metáfora da sociedade pós-histórica como um formigueiro composto por formigas criativas (Flusser, 2008).

Pensando sobre a internet como uma tipologia de espaço social, cientistas sociais têm se interessado em criar mapas das interações online, a fim de melhor compreender o comportamento humano. Dada a ampla atividade em redes de computadores, os pesquisadores podem coletar vastas quantidades de informações sobre o comportamento do formigueiro vislumbrado por Flusser.

Um exemplo de grafo obtido a partir do entrecruzamento de dados na rede, são estas imagens que representam o núcleo da blogosfera.

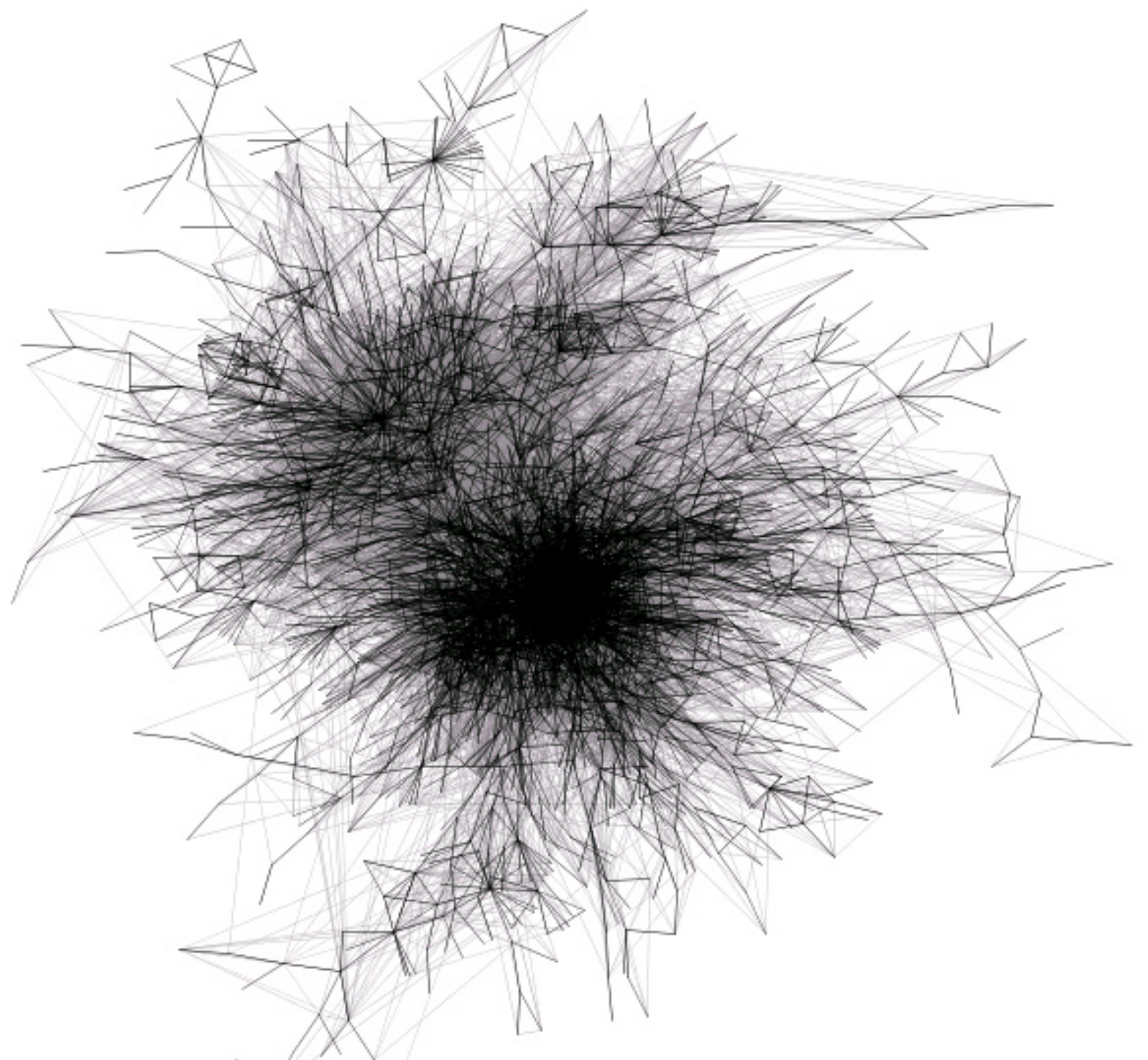

Figura 2.2: Grafo que representa os links do núcleo da blogosfera. Fonte: Hurst (2006, website). 


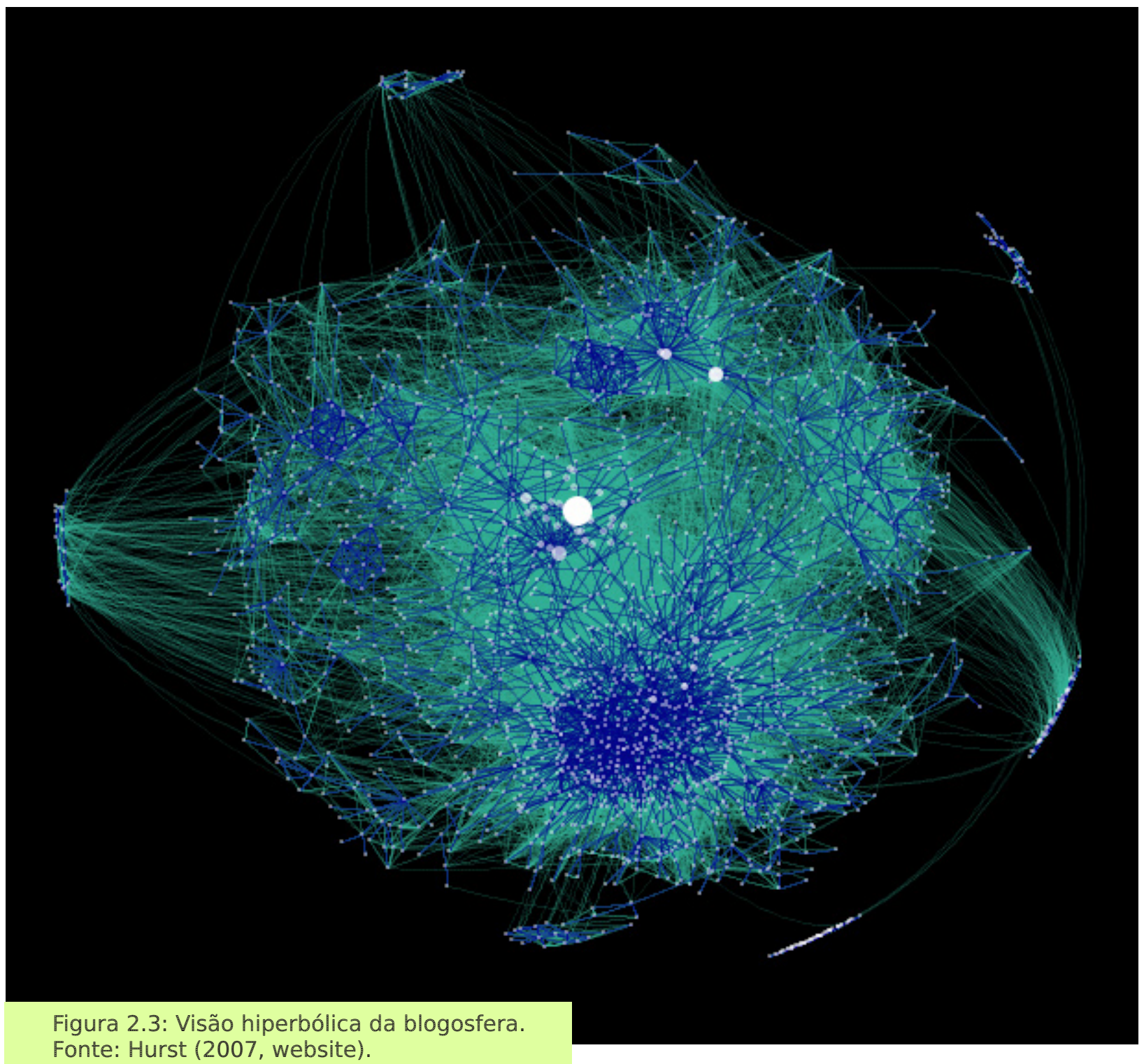

Figura 2.3: Visão hiperbólica da blogosfera.

Fonte: Hurst (2007, website).

No grafo da figura 2.3, segundo o cientista da Microsoft e blogueiro Matthew Hurst, as bordas escuras mostram as relações recíprocas (onde tem um B e B citou A); a área mais densa do gráfico é a parte da blogosfera em geral, caracterizada pela discussão sócio-política (na periferia contém alguns agrupamentos sobre atualidade) e, acima e à esquerda é a área da blogosfera onde se concentram as discussões técnicas e sobre engenhocas (Hurst, 2007).

Analisar pragmaticamente a maneira como são tecidas as linhas de comunicação dentro do sistema social e estético que é a arte, especificamente - sub-sistema Media Art, é tarefa humanamente impossível, e também não é este nosso interesse com esse trabalho. Como coloca Flusser, dada a autopoiesis de um dado sistema, este atende a um programa maior de funcionamento, cujos "emissores" de informação são como cascas de cebola: existem camadas e camadas de programas, que ao serem descascadas, chegase ao nada (Flusser, 2008). Além disso, a autonomia de tal sistema social e estético, não acontece sem nossos constantes esforços na alimentação desse sistema, como pertinentemente coloca Bill Nichols, estamos inserido em 
um sistema pronto a reiniciar, alterar-se, modificar-se ou transformar-se para nós qualquer momento, em qualquer tempo. Interações cibernéticas podem se tornarintensamente exigentes, mais que podemos imaginar a partir de nossa experiência com textos, mesmo envolvendo poderosamente alguns deles.

Nichols, 1988, p.631, tradução nossa ${ }^{44}$

Nessa direção, a partir do olhar cibernético, podemos concluir que construímos um modo de fazer artístico completamente diferente da situação cultural anterior às tecnologias eletrônico-digitais.

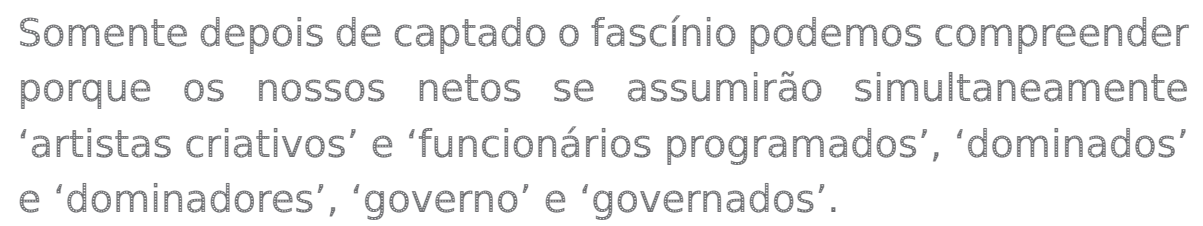

Somente depois de captado o fascínio podemos compreender porque os nossos netos se assumirão simultaneamente 'artistas criativos' e 'funcionários programados', 'dominados' e 'dominadores', 'governo' e 'governados'.

Flusser, 2008, p. 129

A colocação de Flusser aponta para o surgimento de relações humanas em que se assimila a superação da distinção entre ativo e passivo, construção típica da sociedade histórica. Segundo o autor, essa mudança de paradigma também contribui na indeterminação da distinção entre público e privado, fenômeno que também é observado e discutido pela produção de arte eletrônica na contemporaneidade.

\subsubsection{Processo de criação: coordenação}

Sendo a prática da Media Art bastante orientada pelo processo de criação e design de interfaces e interações homem-máquina (Glynn, 2008), buscamos referências também na área de design a fim de compreender a complexidade da produção transdisciplinar.

Discutir tal cenário de produção requer uma aproximação à noção de coordenação. Problemas de coordenação emergem pelo fato de decisões e processos complexos demandarem a organização de diferentes pessoas, conhecimentos e outros elementos que estão interconectados de várias maneiras, o que faz da coordenação uma espécie de gestão das

44 Excerto original: "a system ready to restore, alter, modify or transform any given moment to us any time. Cybernetic Interactions can become intensely demanding, more so than we might imagine from our experience with texts, even powerfully engaging ones" (Nichols, 1988, p.631). 
interdependências entre as atividades para se atingir uma meta (Alexiou; Zamenopoulos, 2007, p.587).

É possível identificar alguns dos principais desafios enfrentados durante a coordenação de processos de design. Para os pesquisadores da área de design e complexidade de universidades inglesas Alexiou e Zamenopoulos, entre eles estão: a necessidade de se estabelecer relações de tradução entre as diferentes formas de representação; sincronizar a troca de informação; e estabelecer papéis e delegar estruturas em organizações. Os desafios listados pelos autores denotam, em certa medida, um conceito de coordenação que abarca as noções de conflito e cooperação. Além disso, eles colocam que a coordenação não pode ser considerada somente como mero gerenciamento, mas também uma atividade relacionada à exploração e geração de soluções alternativas, novas e criativas (Alexiou; Zamenopoulos, 2007, p.588).

Sob a ótica da Cibernética, a coordenação da produção colaborativa de Arte Eletrônica não pressupõe a centralização das atividades criativas. Ao trabalharmos com profissionais de diferentes especialidades, à medida que as funções e responsabilidades são delegadas, as decisões são tomadas a partir de metas individuais no nível local, sem nenhuma fonte centralizadora de controle, compondo um processo de controle distribuído da qual emergem as soluções de design.

Tarefas de design colaborativo requerem que o conhecimento esteja distribuído entre os agentes locais, e a coordenação envolve a síntese e a construção do conhecimento necessário para a tarefa coletiva. Neste sentido, o aprendizado é visto como um instrumento importante não somente para potencializar a habilidade individual dos agentes e assim derivar soluções de design, mas também para criar conhecimento compartilhado sobre tarefas de design e suas limitações (Alexiou; Zamenopoulos, 2007, p.589).

Nesta concepção, a exploração, geração e reformulação paralela de problemas e soluções se tornam uma responsabilidade coletiva, em consonância com a noção de "inteligência coletiva" do filósofo francês Pierre Lévy:

uma inteligência distribuída por toda parte, incessantemente valorizada, coordenada em tempo real, que resulta em uma mobilização efetiva das competências. Acrescentemos à nossa definição este complemento indispensável: a base e o objetivo da inteligência coletiva são o reconhecimento e o enriquecimento mútuo das pessoas, e não o culto de comunidades fetichizadas ou hipostasiadas.

Lévy, 1998, p. 28-29 
Para melhor compreender o modelo de coordenação descrito por Alexiou e Zamenopoulos é importante desenvolver as relações estruturais entre o micro universo dos agentes individuais e o macro universo em que o todo é coordenado e se faz coerente. Considerada como fundamental para se entender o aspecto social do design, diferentes autores abordam a ligação entre micro e macro, a citar o sociólogo britânico Anthony Giddens e o diretor italiano do Istituto Di Scienze e Tecnologie della Cognizione Cristiano Castelfranchi.

Com base na análise das correntes teóricas dos dois autores mencionados, Alexiou e Zamenopoulos afirmam que a maneira com que os agentes interagem, se juntam ou se diferenciam (em termos de metas e crenças), é refletido na organização espacial no nível macro. As ações individuais, guiadas por metas e crenças, é a base para a criação no nível macro. Micro e macro não exatamente correspondem ao problema e à solução de espaço; mas à sua expressão nas escalas individual e global, respectivamente (Alexiou; Zamenopoulos, 2007, p.594).

Interessante ressaltar que a maneira como essas duas instâncias estão relacionadas toca inclusive na característica cerne de nossa análise sobre produção de Arte Eletrônica, a dinâmica entre o programa e o acaso, entre o intencional e o nãointencional:

A distância percebida (ou erro) entre os efeitos intencionais e não-intencionais não apenas motiva a ação, mas também é usada como uma métrica das limitações e restrições sobre estas ações. $\mathrm{Na}$ realidade, os agentes estão delimitados de duas formas: uma está relacionada às limitações dos recursos disponíveis, leis e outras restrições externas, e a outra está relacionada à habilidade de um agente para aprender, interpretar ou internalizar o mundo externo e, portanto, formar as expectativas e previsões sobre ele.

Alexiou; Zamenopoulos, 2007, p.593,
tradução nossa 45

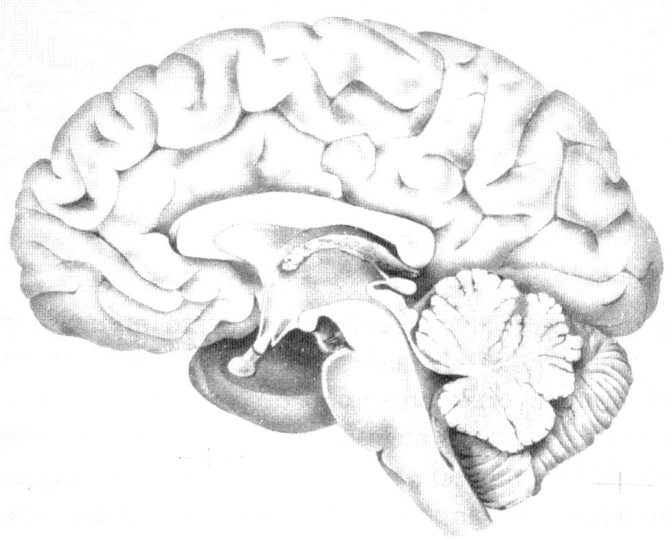

Diagrama do cérebro humano (Cortesia de Mittermeier)

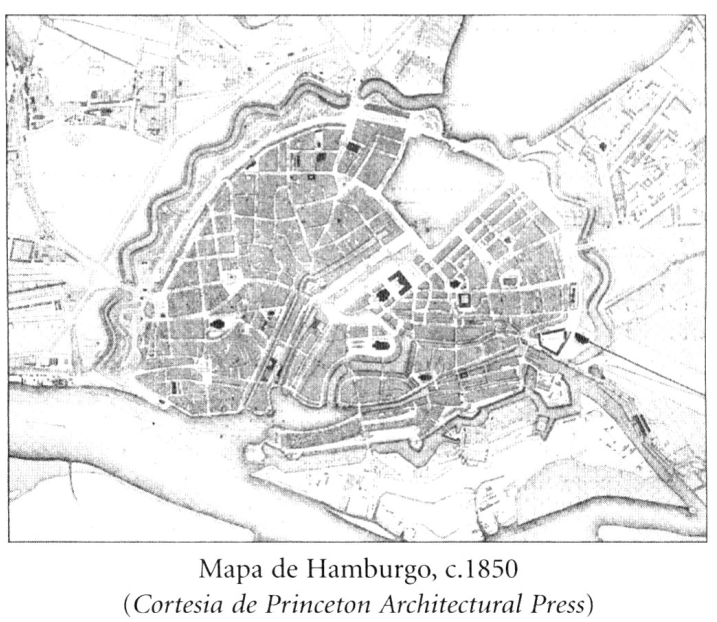

Figura 2.4: Semelhança de manifestações emergentes nos níveis micro e macro: cérebro e mapa de Hamburgo: imagens do livro "Emergência" de Steven Johnson. Fonte: Johnson (2003, p.7)

\footnotetext{
45 Excerto original: "The perceived distance (or error) between the intended and unintended effects not only motivates action, but is also used as a metric of the limitations and constraints over that action. In reality, agents are bounded in two ways: one is related to the limitations of available resources, laws and other external constraints, and the other is related to the ability of an agent to learn, interpret or internalise the external world and therefore form expectations and predictions about it' (Alexiou; Zamenopoulos, 2007, p.593).
} 
A partir dessas colocações, podemos considerar que no caso de processos de design, o modelo de coordenação que olha para os efeitos intencionais e não-intencionais contribui funcionalmente na criação e no gerenciamento da dinâmica das relações entre micro e macro. Esta perspectiva considera o mund o como um campo onde se manifestam ações recursivas simultaneamente convergentes e conflituosas, cujos agentes interagem baseados no conhecimento que possuem do mundo para guiar suas ações futuras (Alexiou; Zamenopoulos, 2007, p.593).

Mesmo em suas particularidades, as diferentes abordagens da relação entre micro e macro entendem as conseqüências não-desejadas das ações como um importante papel na delimitação e/ou condicionamento das atividades, e se constituem como uma fonte importante de variação de estrutura. Esboçar as ligações entre o micro(agente) e macro(estrutura) significa a necessidade de, por um lado, explicar a estabilidade das estruturas sociais apesar das ações ou violações do indivíduo; de outro, a variabilidade, a criatividade e a inovação (Alexiou; Zamenopoulos, 2007, p.591).

\subsection{Entre 0 acidente e o programa}

Neste sub-capítulo, apresentaremos como acidente e programa, além de serem elementos constitutivos das imagens sintéticas, conforme discorrido no capítulo um, também norteiam os processos criativos e a própria noção de criatividade na área de Arte Eletrônica.

Uma mudança fundamental constatada no processo criativo desenvolvido junto às tecnologias eletrônico-digitais é a revisão dos papéis de atuação dos criadores.

A nova função que assume o criador em relação a uma obra
gerada a partir do computador é, segundo Moles, por um lado,
a do esteta e, por outro, a do programador. Esteta no sentido
de que ele deve estabelecer todos os critérios artísticos da
obra que será produzida pelo programa, enquanto que sua
função prática é a de realizar o algoritmo que abranja esse
leque estético, traduzindo as necessidades criativas para a
linguagem binária da máquina.

Giannetti, 2006, p.43

Flusser utiliza também os conceitos de acaso e programa para discorrer sobre a criatividade. Para ele, a criatividade da situação cultural emergente é baseada em um "preparar-se", uma "criatividade disciplinar". Não estamos mais condenados a criar somente pela intuição ou inspiração, podemos criar 
disciplinarmente. Neste contexto, enquanto o artista busca por algo, dentro de sua metodologia - e aqui ele se assemelha e se aproxima do cientista - ele se programa para executar o seu projeto.

O processo enfrentado por Gordon Pask e McKinnon Wood, criadores do sistema "Musicolour" (1953) (figura 2.5), durante as várias experimentações que fizeram com a máquina que criaram é um exemplo interessante para demonstrar como as relações entre acidente e programa também estão presentes na Media Art para além do nível estrutural e constitutivo. No diálogo com profissionais de outras áreas de atuação, surgiram diferentes possibilidades de aplicação para o sistema criado por eles. Entre outras iniciativas, os artistas combinaram a performance de marionetes com o "MusiColour". Apesar das dificuldades encontradas para a implementação, nos ensaios, as criaturas mecânicas criadas responderam satisfatoriamente como output do sistema. Porém, na primeira noite de apresentação, acidentes desastrosos envolveram os dispositivos mecânicos. O acidente não desanimou o grupo. Uma vez que possuíam o teatro reservado para o mês todo, investiram em um workshop público, explorando as potencialidades musicais do sistema.

Segundo Flusser, a crítica da objetividade diria que "não há momento decisivo no processo criativo, porque todos os acasos possíveis, inclusive os extremamente pouco prováveis, estão inscritos em programa e se realizarão automaticamente mais cedo ou mais tarde" (2008, p.119). E, para a crítica da subjetividade, da qual o autor é

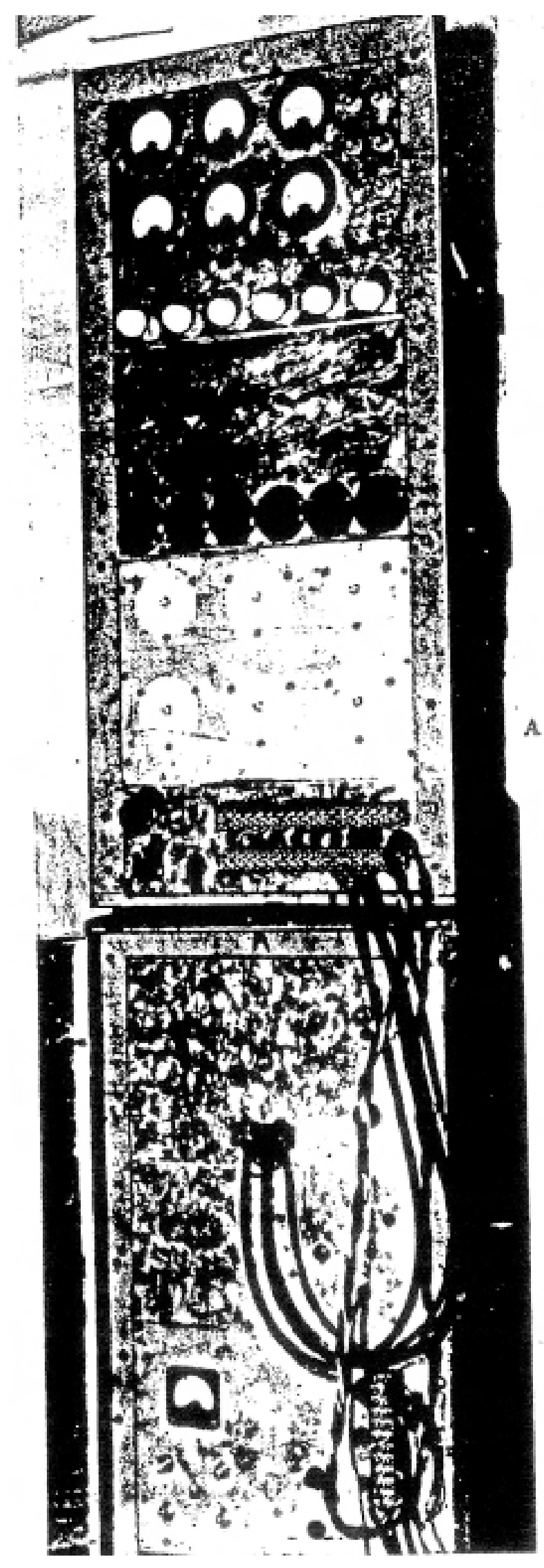

Figura 2.5: Musicolour Machine (1953, Meca Locarno, Streatham): obra de Gordon Pask e Robin McKinnon. Fonte: Pask (1968, p. 82). 
partidário, "o momento decisivo no processo criativo é a descoberta de um acaso que, embora inscrito no programa, permite quebrá-lo: esse momento de descoberta é resultado de busca, de 'preparação' disciplinada" (2008, p.119).

Com base em nossos exemplos e nas críticas de Flusser, começamos a compreender com mais clareza a complexidade das mudanças de paradigmas que enfrentamos frente à cultura eletrônico-digital. Se, como disse Gordon Pask, o homem vive a procurar novidades em seu ambiente e encontrandoas tem a necessidade de controle sobre elas (Pask, 1968), como se dá esse controle na produção colaborativa da era digital?

Em um processo de design coletivo, um novo padrão ou comportamento se forma no nível macro a partir da interação dos agentes a nível local. Nestes casos, a emergência é desejável, por abrir a possibilidade do surgimento de comportamentos que podem atingir uma determinada tarefa ou meta sem a existência de um mecanismo central dirigindo as atividades dos agentes para este fim. Nesta situação a coordenação é exatamente o efeito desejável e emergente das atividades dos agentes distribuídos. Apesar do coletivo partilhar um mundo comum, eles tem suas visões individuais deste mundo. E assim, cada agente incorpora um processo de controle, que gera ações de controle ou de tomada decisões para atender em tempo variável a objetivos individuais, apesar das incertezas endógenas e exógenas e de perturbações provenientes das ações de outros agentes.

Segund o Alexiou e Zamenopoulos, este processo de controle é alimentado pela aprendizagem. Cada agente a prende a formar as reações de outros agentes e desenvolve expectativas sobre o mundo, as quais não somente transmitem conhecimentos sobre os efeitos das decisões de projeto e do desempenho do artefato projetado, mas também estabelecem a relação entre os objetivos e as soluções de concepção. É por meio deste conhecimento que os agentes descobrem as ações para conduzir o sistema global em direção às metas individuais e evitar conflitos com outros agentes (Alexiou; Zamenopoulos, 2007, p.589-90). Além desta habilidade, no paradigma de processo criativo coletivo, se faz necessário o constante acompanhamento da discrepância entre as expectativas e os estados reais do mundo(Alexiou; Zamenopoulos, 2007, p.590).

A partir desta perspectiva, nossa "necessidade de controle" paradoxalmente se mantém e dialoga como os fenômenos de nossa era de indeterminação. Seria precisamente no jogo entre essas duas tendências que o jogo criativo emerge? 
A indeterminação intrínseca à participação do interator na obra é uma das principais questões para os artistas contemporâneos, e seguramente contamina também o processo criativo. O mídia-artista sul-coreano Nam June Paik, por exemplo, influenciado pelo músico norte-americano John Cage e pela Cibernética, buscava em seus processos de criação relacionar o conceito de
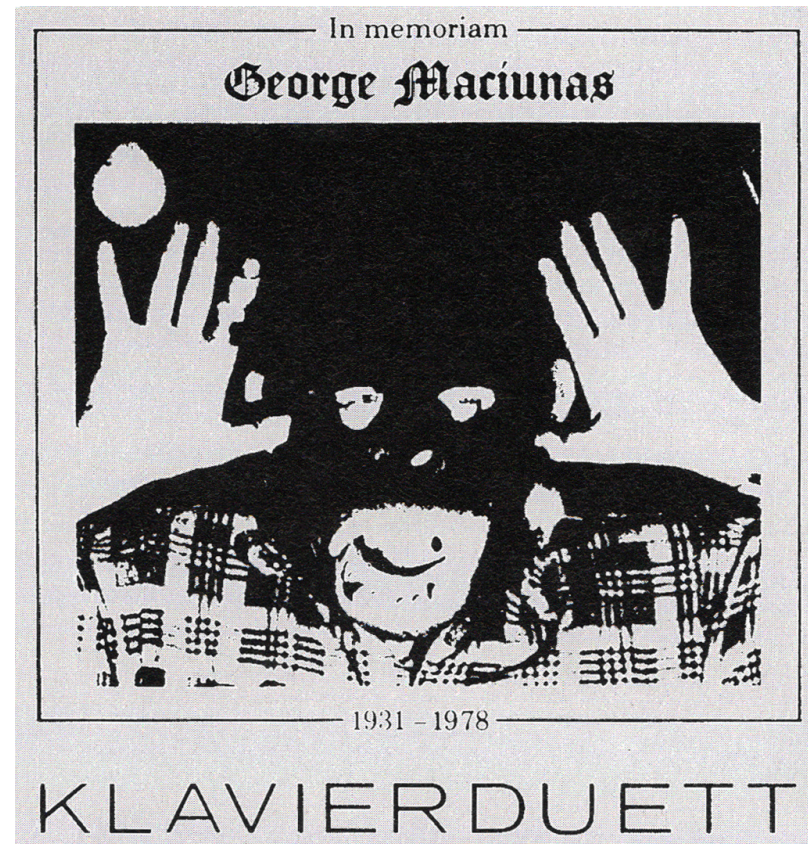
Joseph Beuys \& Nam June Paik

Fluxus-Soirée der Galerie René Block in der Aula der Staatlichen Kunstakademie Düsseldort

Freitag, 7. Juli 1978, 20 Uhr Unkostenbeitrag DM 10.- (Akademiestudenten DM 4.-)
Figura 2.6: (ao lado) Cartaz de divulgação da performance de Joseph Beuys e Nam June Paik em homenagem à George Maciunas na Academia de Arte de Düsseldorf.

Figura 2.7: (acima) Nam June Paik e Joseph Beuys em performance. Foto: Ivo Dekovic. Fonte: Rennert; Wiese (1996, p. 72-3).

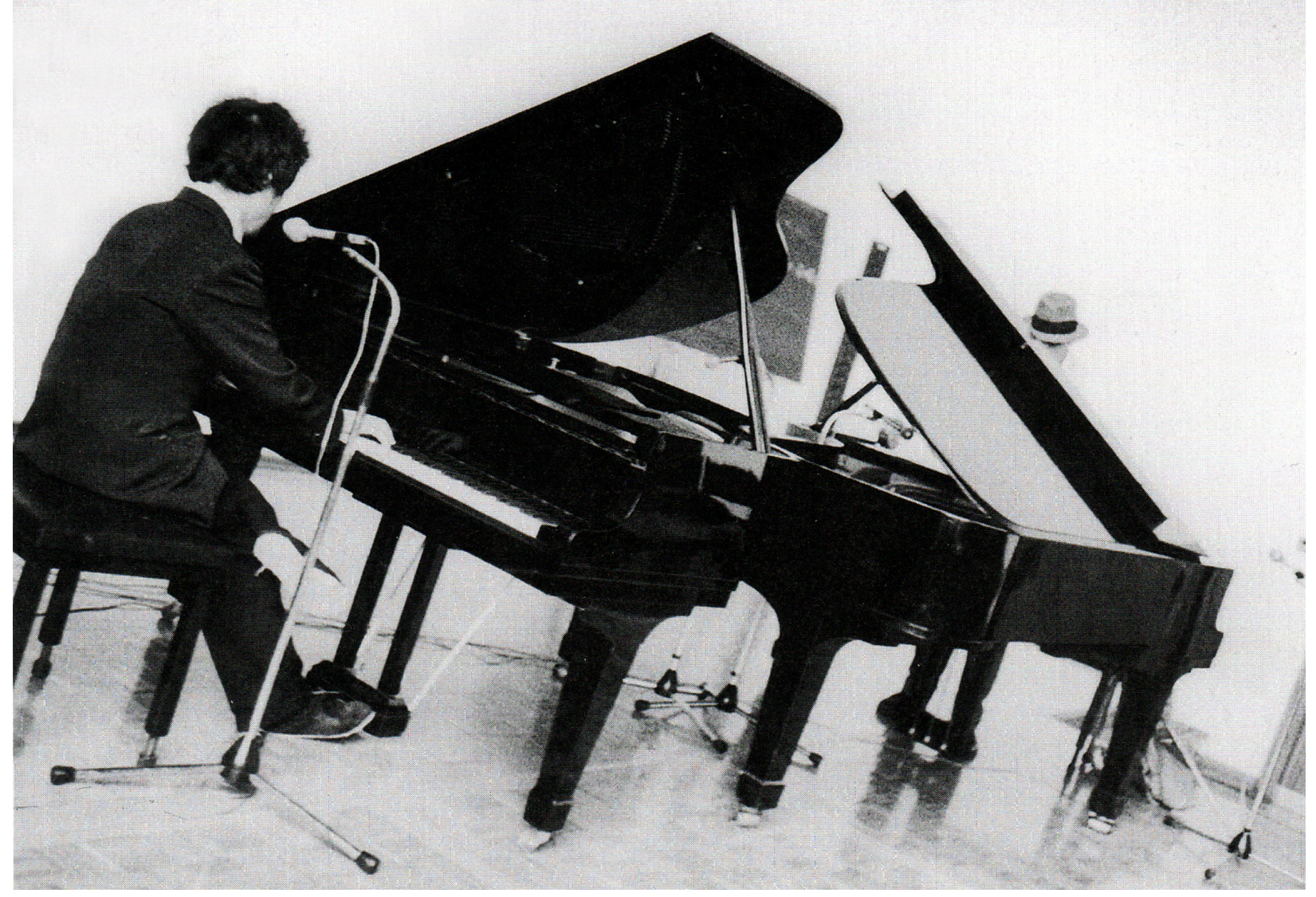


liberdade com os problemas de comunicação na arte. Suas obras propunham "a comunicação não como um modo de transmissão de mensagens informativas ou explicativas, mas como uma forma de interação livre entre público e obra" (Giannetti, 2006, p.51).

Nestas proposições, os distúrbios e as instâncias acidentais não são considerados apenas como uma fonte de conflito, mas também como uma fonte de variabilidade e, portanto, uma oportunidade para que a novidade emerja (Alexiou; Zamenopoulos, 2007, p.590), tanto no nível local (indivíduos) como para o nível global (o programa maior a ser cumprido pelo coletivo).

Retomando à Cibernética, no diagrama sintetizador de Peter Solderitsch, o que poderíamos comparar ao acaso definido por Flusser, seria a noção de "disturbances", apontada como interferências geradas pelo ambiente no qual se insere o sistema observado (Solderitsch, 2003).

$\mathrm{Na}$ estética dos processos e dos sistemas da Arte Eletrônica, tanto o "acaso" apontado por Flusser como os "distúrbios" apontados por Solderitsch podem ser incorporados na criação e na fruição artística como aspectos da imprevisibilidade e da indeterminação de nossa atual situação cultural. Acasos ou distúrbios, ao serem assimilados no processo, ao mesmo tempo que afligem e tensionam os realizadores, podem ser observados de maneira construtiva na criação e na fruição, como característica incentivadora do diálogo. Se um criador se depara com um problema aparentemente insolúvel que surgiu durante o fazer, movido pela "necessidade de controle", ele imediatamente buscará respostas em informações produzidas por pessoas que já passaram pelo mesmo problema, ou mesmo tentará diálogos diretos com as pessoas que já viveram ou tangenciaram aquela situação.

Além disso, a noção de "controle" da Cibernética nos ajuda a relativizar suas dimensões. Evocamos aqui a definição do arquiteto ciberneticista inglês Ranulph Glanville acerca do termo "controle":

\begin{tabular}{|c|}
\hline $\begin{array}{l}\text { o ato pelo qual um sistema (c } \\
\text { comportamento de outro sistema } \\
\text { que seu comportamento é mais do } \\
\text { Contudo, a investigação mostra que } \\
\text { que controlador e controlado são pa } \\
\text { um observador }\end{array}$ \\
\hline Glanville, 2001, p. 2 , tradução nossa 46 \\
\hline
\end{tabular}

Para Flusser, a criatividade da situação cultural emergente é baseada em um "preparar-se". Trata-se da "criatividade disciplinar". Neste contexto,

46 Excerto original: "the act by which one (controller) system shapes the behavior of another (controlled) system, so that its behavior is more to the liking of the controller. However, investigation shows that control is circular and that controller and controlled are roles determined by an observer" (Glanville, 2001, p. 2). 
enquanto o artista busca, dentro de sua metodologia - e aqui ele se assemelha e se aproxima do cientista - ele se programa para executar o seu projeto. Durante essa busca, segundo Flusser, a criatividade se encontra na abertura do "eu" para - acaso muito pouco provável. E não apenas abertura, mas também a tomada de decisão: "é precisamente em tal decisão em prol do pouco provável em meio muito provável que reside o núcleo da criatividade" (Flusser, 2008, p.118).

Essa proposição também estabelece um diálogo com a concepção de variantologia, de Siegfried Zielinski. O termo "variantologia" é um neologismo utilizado pelo autor na série homônima de publicações sobre o tema. De acordo com ele, a iniciativa é uma forma de reação à cultura de formação de blocos e da estandardização programática que assola as diversas áreas do conhecimento nos dias de hoje (Zielinski; Wagnermaier, 2005, p.7-8).

$\mathrm{Na}$ decisão a favor do acaso menos provável a que se refere Flusser também se concentra um dos pontos considerados por Zielinski como de crucial importância no engajamento com as mídias eletrônicas: o senso do risco. Ao comentar sobre este aspecto, Zielinski remonta ao filósofo e sociólogo alemão Dietmar Kamper, o qual lembra que o termo illudere (de iludir, no que aliás as mídias são historicamente especialistas) "não significa apenas fingir ou simular alguma coisa, mas também inclui o sentido de arriscar alguma coisa, talvez até mesmo uma própria posição ou convicção"(Zielinski, 2006, p.10-11, tradução nossa $\left.{ }^{47}\right)$.

Na publicação "Risk"(2007), Luhmann lembra que antropologistas culturais e sociais assinalam que a avaliação do risco e a vontade para aceitá-lo não são apenas problemas psicológicos, mas sobretudo problemas sociais. O sujeito, além de trafegar por áreas que não tocam o limiar do desastre, atua em conformidade com as expectativas do grupo a que pertence. De certa forma, este aspecto enfatiza a contextualidade variável das situações de risco (Luhmann, 2007), evidenciando inclusive as profundas relações entre micro e macro.

A seguir, desecrevemos alguns exemplos do fazer artístico nas condições colaborativas que procuramos caracterizar.

\subsection{Experiências estéticas cibernéticas}

\subsubsection{Experiências coletivas telemáticas: "La Plissure du Text"}

Como os aspectos estruturais e constitutivos da comunicação entre as partes do sistema de uma instalação interativa já foi explorado no primeiro

${ }^{47}$ Excerto original: "not only means to feign or simulate something, but also includes the sense of risking something, perhaps even one's own position or convictions" (Zielinki, 2006, p.10-11). 
capítulo; neste o intuito é demonstrar os aspectos cibernéticos nos âmbitos do fazer (criação e produção) e da experiência proporcionada pela proposta (fruição). Para isso, começaremos observando o trabalho do artista inglês Roy Ascott.

Ascott está entre os artistas pioneiros a considerar a cibernética e a telemática no fazer artístico, desde a década de 1960, focando seu trabalho na questão do impacto das mídias digitais e das redes de telecomunicações na consciência e no conhecimento (Ascott, 2003). Sintetizando avanços da ciência e da tecnologia em arte experimental e em antigos sistemas de conhecimento, a teoria e a prática visionárias de Ascott aspiram ampliar a consciência humana e unir mentes ao redor do mundo em um abraço global telemático, maior que a soma de suas partes (Ascott, 2003).

Atestando que apesar de lidarmos com objetos, somos orientados por processos, Roy Ascott tinha o propósito de criar o que ele nomeou "Cybernetic Art Matrix", algo que tanto na escala social como na escala íntima dos artefatos criados por ele, constituía-se como processos desencadeadores (Ascott, 1968, p. 105).

Trabalhos de arte podem também desencadear respostas de espécie polêmica ou social encorajando em sua audiência mudanças no comportamento individual ou grupal pelo questionamento de preconceitos, destruindo ilusões por meio de choques do não-familiar, absurdos ou metáforas incongruentes. Dentro do mesmo contexto mais sóbrio, a construção dialética de valores abstratos tem sido desenvolvida para apresentar ao observador a possibilidade de um novo comportamento social.

Ascott, 1968, p, 107, tradução nossa48

Em 1983, o historiador de arte e tecnologia Frank Popper convidou Ascott para um projeto na exibição intitulada Electra, no Musée d'Art Moderne de la ville de Paris, com o tema da história da eletricidade tomando a arte como fio condutor. Neste contexto, Ascott organizou a obra "La plissure du texte" (A dobra/prega do texto), um conto de fadas planetário, em que o artista explora a capacidade de uma rede de computadores na criação interativa e colaborativa de um trabalho de arte (Ascott, 2003, p.64-5). Cerca de dez anos antes da internet se constituir como tal, Ascott, interconectou 11 cidades espalhadas pela Europa, América do Norte e Austrália. Para cada ponto de conexão ele atribuiu

\footnotetext{
48 Excerto original: "Art works may also trigger off responses of a polemical or social kind encouraging in their audience changes in individual or group bahaviour by questioning preconceptions, destroying illusions by means of the shock of unfamiliar, absurd or incongruous imagery. Within the same context a more sober, dialectical construction of abstract values has been developed to preent the observer with the possibility of a new social behaviour" (Ascott, 1968, p, 107).
} 
um personagem arquetípico dos contos de fadas. No período de três semanas foi produzida uma narrativa que poderia ser escrita em inglês ou francês. Para começar, Ascott atuou como um mágico em Paris, iniciando a interação com a frase "Era uma vez..." e a partir disso, cada ponto conectado redigia parte da narrativa a partir da perspectiva de seu personagem correspondente (Ascott, 2003, p.64-5).

Esta proposição de Roy Ascott se referencia à obra "Le Plaisir du text", de Roland Barthes (1973), em que o autor explora através de narrativa nãolinear a intertextualidade. Como numa espécie de online Role Playing Game (RPG), o artista desencadeou um processo de relações entre os participantes
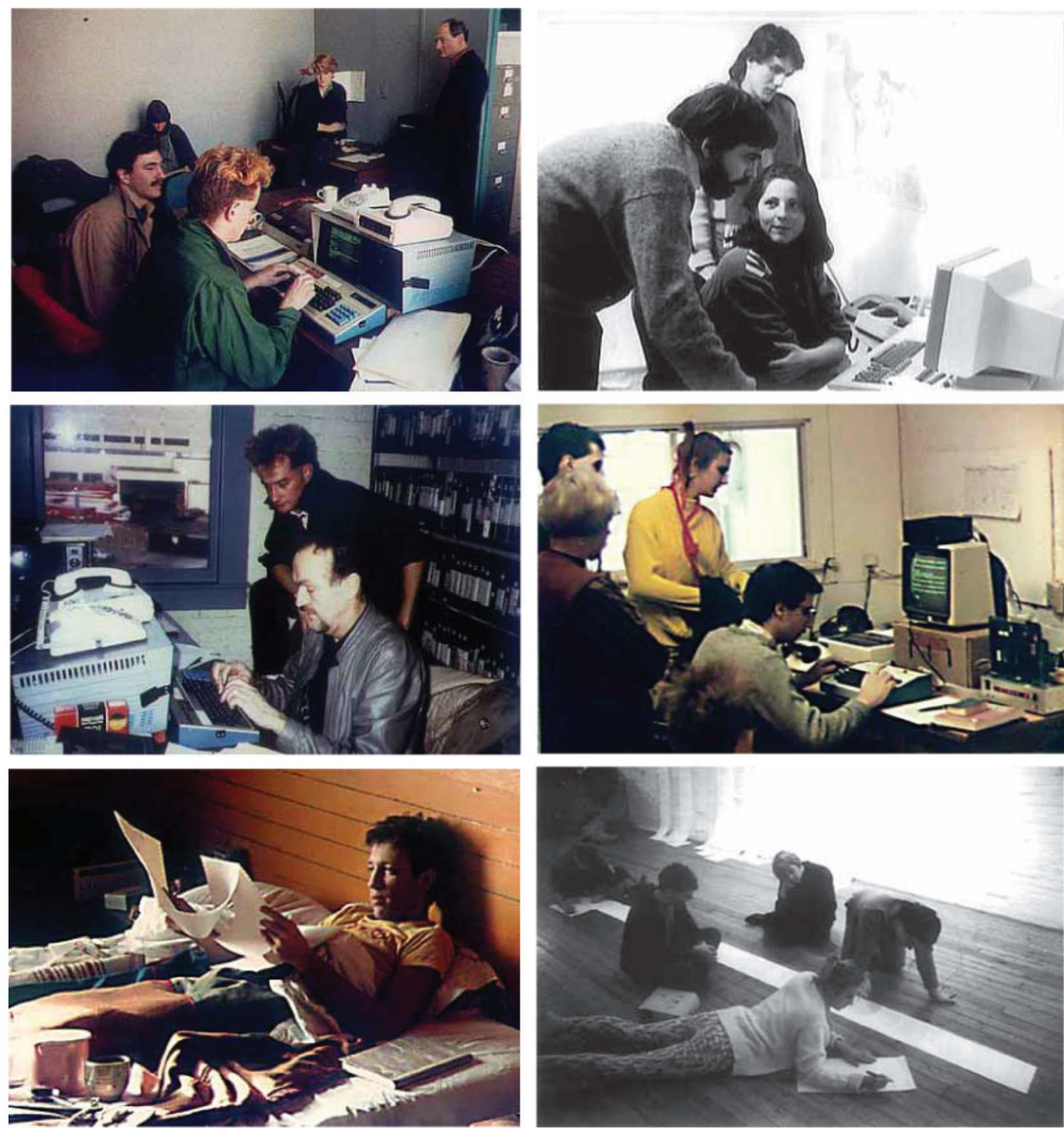

Figura 2.8: Participantes de "La Plissure du text" em várias cidades ao redor do mundo. De cima para baixo, da esquerda para a direita: T. Klinkowstein \& G. McKenna no La Mammelle (São Francisco, EUA); Zelko Wiener e colegas no Kulturservice Studio (Viena, Áustria); T. Klinkowstein \& R. Adrian no La Mammelle (São Francisco, EUA); Estudantes do Ontario College of Art na Music Gallery (Toronto, Canadá); Hank Bull no Western Front (Vancouver, Canadá); Estudantes do Ontario College of Art na Music Gallery (Toronto Canadá). Fonte: Ascott (1983, website). 
de forma que a ação criativa e a experiência proporcionada não mais se separam temporalmente; as duas instâncias ocorrem simultaneamente e têm seus limites borrados. Ascott afirma ter se inspirado também no texto " $L$ 'ordre du discours" (1971), do filósofo francês Michel Foucault, embora este nunca tivesse mencionado algo sobre autoria distribuída em seu livro (Ascott, 2003, p.190-1).

Considerada pelo editor da revista Leonardo Roger Malina como um marco na história da arte telemática, "La Plissure du Text" constituiu-se como uma rede criativa que desafiou os conceitos tradicionais de artista, obra de arte e observador (Ascott, 2003, p.66). Na seqüência deste trabalho, Ascott se engajou na realização de projetos que envolvessem telematicamente um público vasto, o que resultou, por exemplo, na criação de "Organe et Function d'Alice au Pays des Merveilles", na ocasião da mostra de arte "Immatériaux", curada por Jean-François Lyotard e Thierry Chaput, em 1985 na cidade de Paris. Neste caso, a obra/sistema poderia ser acessada por qualquer pessoa do público conectada ao Minitel, um sistema francês de videotexto implementado em 1981. Essa experiência coordenada por Roy Ascott contribuiu para impulsionar o questionamento das noções tradicionais de originalidade, autenticidade, da natureza do objeto, narrativa e estilo, termos que foram enriquecidos com as noções de apropriação, duplicação, distribuição, justaposição e entropia (Ascott, 2003, p.67).

As proposições de arte telemática citadas, em correspondência com as características da Arte Contemporânea, nos ajudam a compreender os desdobramentos de uma "estética do processo e do sistema"(Ascott, 1968, p.106-7), fundamentada sobretudo nas relações entre os participantes da ação proposta.

\subsubsection{0 processo de criação e a interlocução em "Energie_ Passagen"}

Dando continuidade aos nossos exemplos, tomaremos como modelo contemporâneo (pós anos 1990), o trabalho do casal de artistas e pesquisadores alemães Monika Fleischmann e Wolfgang Strauss ${ }^{49}$ do MARS (Media Arts Research Studies), situado no Frauenhofer Institut, os quais tivemos a oportunidade de entrevistar durante a fase de coleta de dados da pesquisa.

Strauss e Fleischmann confirmaram na prática alguns dos pontos teóricos abordados por nós nos item anteriores. Segundo os artistas, as mídias eletrônicas demandam muito conhecimento de diferentes naturezas e afirmam ser praticamente inviável realizar tudo solitariamente na área de Media Art. (Fleischmann; Strauss, 2008).

49 Página oficial dos artistas disponível em: http://fleischmann-strauss.de/index.html, acessado em 15/Jun/2009. 
Os artistas, apesar de trabalharem sobre os múltiplos sentidos humanos, o que consideram um aspecto complicador, declaram a importância de haver limitações, pois elas permitem a concentração e aprofundamento em assuntos especiais. Para Fleischmann,

arte sem limitações não tem futuro. De outra forma, ela seria publicidade, a qual tem outro foco, outra direção. Não se trata de juntar pessoas, de querer fazer o máximo possível, e então eu procuro por pessoas de diferentes disciplinas... Eu não sou especialista em audição e música, mas tem alguém com o quem eu gostaria de trabalhar junto.

Fleischmann, 2008, entrevista, tradução nossa ${ }^{50}$

Nossa perspectiva vê esta colocação da artista como uma das formas possíveis de se atestar o caráter dialógico da produção da Media Art. Mesmo que as pessoas se especializem cada vez mais em algum conhecimento, também existe a tendência dessas especialidades se juntarem e estabelecerem conversações.

Ainda em relação ao processo de trabalho dos dois, Fleischmann afirma que não inicia seus projetos a partir de suas referências, e sim que encontram as coisas que se encaixam com suas proposições ao longo do caminho. Ela ainda reitera que só se encontra essas coisas porque se está pensando sobre aquele determinado assunto, porque ele faz parte de sua área de pesquisa. Além disso, encontrar no caminho também pode ocorrer enquanto se dialoga com outras pessoas (Fleischmann, 200851).

Desde as primeiras ideias, passando pelos rascunhos e sketches até a programação, o intuito de Fleischmann e Strauss ao lidarem com a estética interativa é oferecer às pessoas o envolvimento em uma "paisagem de ideias"52, demandando à elas que façam parte do trabalho. Eles vêem o processo de interatividade como uma "contação de histórias iniciando em um estrutura escondida" 53 , em que as pessoas ao interagirem elas recontam a história através do comportamento delas, respondendo ao diálogo proposto inicialmente pelos artistas. Podemos dizer que essa postura dos artistas cria aberturas para o acaso e para o inusitado tanto no processo de criação quanto

\footnotetext{
50 Excerto original extraído de entrevista realizada em 25/abril/2008 em Osnabrück, Alemanha: “Art with no limitations there is no future. Otherwise it is advertising, which hás another focus, another direction.> it is not about getting people together, it is not about I want to do as much as it is possible, and therefore I look for people from different disciplines... I am not specialist in hearing and music, but there is someone I want to work with." (Fleischmann, 2008).

51 Excerto da entrevista utilizado: "It's not that we start with references. Usually not. We have always things on the way which fit in. You find because you're thinking about a topic. And then of course you see things, because it fits in your area of research. Finding on the way could also be a dialogue between people" (Fleischmann, 2008).

52 Termo originalmente utilizado pelos artistas foi “landscape of ideas" (Fleischmann; Strauss, 2008, tradução nossa).

53 Termo originalmente utilizado pelos artistas foi "a storytelling starting in a hidden structure" (Fleischmann; Strauss, 2008, tradução nossa).
} 
para a experiência das pessoas.

Comoum dos resultados desta maneira de trabalhar dos artistas analisamos - processo de criação da instalação interativa "Energie_Passagen"54, exibida em frente à Literaturhaus (Casa da Literatura) de Munique em 2004. A proposta consistia em transformar o fluxo de notícias diárias em um fluxo audiovisual de informação, projetados no chão como uma mídia de leitura. Uma técnica automática converte os RSS feeds diários de jornais, analisa cerca de 50 mil palavras e em seguida seleciona as 500 palavras mais recorrentes nas notícias. Essas palavras, além de projetadas, são lidas por uma voz artificial de computador, e o público pode selecionar os termos via reconhecimento de voz ou toque na tela. A palavra selecionada se junta a um grupo de "palavras amigas", permitindo ao leitor/interator uma leitura associativa, em que lhe é dada a possibilidade de ressignificar as palavras em contextos diferentes do inicial. Segundo os artistas, a proposta dialoga com a ideia de que a "linguagem é entendida como energia intelectual" (Fleischmann; Strauss, 2008, p. 86, tradução nossa55).

Vista pelos artistas como uma forma de "orquestração dos sentidos", neste caso, especificamente da audição e da visão, "Energie_Passagen" lida com tecnologias complicadas (rastreamento óptico, reconhecimento de voz, etc.), mas através de uma interface muito simples no espaço urbano, permite ao público adquirir a habilidade para a interação.

Durante a entrevista realizada, os artistas nos contaram um pouco da experiência e do feedback do público. Eles contam que o mote inicial da proposta era medir a energia da cidade, e na seqüência, prospectaram canais de fomento para produzir o trabalho. Após três meses pensando sobre o tema, eles chegaram na proposta de lidar com a energia mental da cidade. E só então que entraram as preocupações técnicas do trabalho, cujas atividades vão desde a familiarização com as ferramentas disponíveis até a combinação entre elas. Dessa forma, o trabalho vai se tornando cada vez mais preciso e específico, sendo necessário a todo instante retornar aos aspectos estéticos do contexto, avaliando as formas de movimento, o ritmo, as cores, ou se perguntando, por exemplo, "esta voz artificial soa bem?", "ela conversa com você, te envolve?" (Fleischmann; Strauss, 2008).

Segundo os artistas, a participação de diferentes perfis de profissionais durante os processos de criação, experimentação e execução da obra, apesar de ser um fator complicador, é um aspecto fascinante. Além disso, eles reiteraram sobre a atenção que é preciso dedicar à documentação do trabalho, sobre a conveniência de sua construção modular, de forma que seja possível modificálos mais tarde, e sobre as possibilidades da estrutura técnica desenvolvida serem incorporadas pelo mercado, por indústrias ou empresas que possam vir a se interessar.

\footnotetext{
54 Site oficial de divulgação da instalação disponível em http://energie-passagen.de/index.html, acessado em 17/jun/2009. 55 Trecho original em inglês: "language is understood as intellectual energy" (Fleischmann, Strauss, 2008, p. 86).
} 
Já em relação ao retorno do público, Fleischmann colocou o fato das pessoas voltarem para rever o trabalho diversas vezes, sem demandar por explicações, já que elas próprias criavam suas próprias histórias, pois tinham tempo para suas próprias associações. E destaca que para se ter as pessoas envolvidas em trabalhos artísticos interativos, é necessário que sejam criadas condições para que as pessoas possam entender alguma coisa a partir de seus próprios pensamentos (Fleischmann; Strauss, 2008). E, dessa forma o diálogo artista-obra-público se inicia. Depois de quarto semanas em exibição, as pessoas perguntavam: "Por que vocês vão tirá-la daqui?". Para Fleischmann, ao experimentar estímulos especiais aos sentidos, as pessoas se sentiam atraídas a pensarem sobre coisas cotidianas: “O que lemos nos jornais todos os dias? Nós temos tempo para os nossos próprios pensamentos?" (Fleischmann; Strauss, 2008).

Dessa forma consideramos que a instalação "Energie_passagen" constituise como mais um exemplo da estética do processo e dos sistemas (Ascott, 1968), sobretudo por se basear na observação sobre o fluxo de comunicação entre diferentes sistemas interligados, e considerando a presença do observador, característica fundamental da Cibernética de Segunda Ordem, e mais do que isso, por incitar o diálogo com ele. A recursividade não é apenas temática, uma vez que a mídia toma como si própria enquanto tema para a expressão, mas aponta o caminho de mão dupla da influência entre comunicação e percepção. Além disso, a proposta elucida a autonomia das inter-relações criadas entre as pessoas na produção diária de informações. Fatos e notícias são criados por pessoas e consumidos por elas mesmas num processo conversacional infinito.

\subsubsection{Nossa experiência: interlocuções e construção de conhecimento}

Retomando ao exemplo do processo de criação de "Don't Give Up!", exercício prático utilizado como forma de coleta de dados para este trabalho, podemos dizer que, antes de mais nada, o propósito da criação constituiu-se como uma atividade de valorização do processo, da aprendizagem e dos êxtases intelectuais que a atividade proporcionou. Como no elogio à superficialidade que nos inspira Flusser, demos importância às relações que se estabeleceram entre as pessoas participantes do processo, como numa aventura técnico-criativa num efêmero espaço-tempo.

Hoje, com um distanciamento crítico de nosso experimento estético, identificamos que a tensão entre interator e sistema (narrativa) colocada na forma de interação com a instalação coincidiu com a situação da pesquisadora e o objeto de pesquisa. O processo investigativo da atividade de pesquisa é metaforicamente colocado no título e na dinâmica do funcionamento da instalação. 
Durante o processo de concepção e produção do projeto, à medida que afinávamos os conceitos com o design da interação, também participamos de um processo circular de relações entre sujeitos de diferentes especialidades e repertórios que, ao comunicarem suas opiniões contribuíram de alguma forma para o sistema interativo construído. Abertamente influenciado pelo frutífero processo conversacional, o projeto inicial se transformou muito em relação à instalação executada ao final da primeira etapa do processo, a primeira exibição. E enquanto ela for remontada estará sujeita a alterações, como arteprocesso.

As referências e informações que as pessoas traziam durante conversas sobre os conceitos e técnicas a serem trabalhados na instalação davam abertura para possibilidades inimaginadas anteriormente. Definitivamente não se tratava de um trabalho que poderia ter sido feito por uma única pessoa, foi necessário encontrar parceiros, como a animadora romena Andreea Jabelean. $E$, podemos dizer que, durante a coordenação do processo, conforme as funções e responsabilidades foram delegadas, as decisões foram tomadas a partir de metas individuais, sem nenhuma fonte centralizadora de controle. Mesmo criando coletivamente as histórias, as decisões estéticas de Jabelean ao desenhar eram próprias dela, em consonância com o que ela desejava para compor seu portifólio. E a motivação para participar no Ars Electronica contava ainda com motivos bastante pessoais, no âmbito das relações familiares.

Flusser vislumbrou uma sociedade emergente pautada na negação do mundo objetivo, e que vivesse no "mundo concreto dos sonhos". Sonhos que emergem por interação e interferência complexa de funções. Metaforicamente, ele se referiu a essa sociedade como um imenso formigueiro, em que os sujeitos que a compõem são formigas curiosas e criativas (Flusser, 2008, p.131). Nos processos criativos e executivos da Arte Eletrônica, artistas, cientistas e técnicos se juntam em determinado propósito imaginado. Movidos pelos ímpetos pessoais no nível micro(local), eles agem no nível macro (global), o qual é essencialmente tecido a partir de fios invisíveis das relações de comunicação envolvidas no processo.

No processo de remontagem da instalação no FILE - Festival Internacional de Linguagem Eletrônica, em Julho de 2009 na cidade de São Paulo, emergiram outros contextos de interlocução. Novas trocas de conhecimento já se iniciaram com a remontagem da maquete junto ao técnico de marcenaria. A montagem no local da exposição acrescentou outra camada de interlocuções. A contribuição de outros técnicos, as conversas e trocas de informações com outros artistas exibindo no festival geraram o aprimoramento das nossas soluções técnicas. Além de fomentar o nosso preparo para a criatividade disciplinada flusseriana, foi um momento em que pudemos dar continuidade no processo de reconhecimento de nossos pares, de dialogar com pessoas 
com buscas semelhantes. Num espaço-tempo específico e condensado nos dias de montagem, sentimos o formigueiro criativo de Flusser se formar, com as formigas todas trabalhando.

Outras camadas de interlocução ocorreram junto aos monitores da exposição e junto aos visitantes do festival, sendo que alguns deles responderam a um questionário de feedback. Outros visitantes ainda nos contactaram via e-mail para se informar de detalhes conceituais e técnicos da instalação, ou mesmo apenas para expressar a alegria de ter experimentado nossa proposta.

No File Symposium, em que tivemos a oportunidade de contextualizar nossa pesquisa em seu âmbito acadêmico, abriu-se a possibilidade de outro nível de interlocução. Um senhor que se apresentou como um inventor, nos colocou que a nossa proposta de interface, as cordas, os inspiraram para a ideia de um projeto em que as pessoas gastariam energia em tarefas cotidianas e ao mesmo tempo pudessem se divertir. Através deste exemplo, sentimos que, mesmo que em baixa escala, iniciamos a abertura de um processo desencadeador, como almejava Roy Ascott com a proposição de uma "Cybernetic Art Matrix".

Apossibilidadedeparticipardeste processo desencadeou outrasquestões. Essa experiência conversacional nos deu abertura para questionarmos inclusive o contexto brasileiro de produção de Arte Eletrônica. Entre outros fatores, a ausência de cursos de graduação voltados especificamente para o ensino de Media Art faz como que a produção brasileira tenha presença bastante tímida em festivais brasileiros de caráter internacional. No FILE por exemplo, haviam apenas 7 brasileiros entre os 70 artistas exibindo seus trabalhos. Nossa cadeia produtiva na área de Media Art ainda é incipiente. Temos de um lado artistas consagrados, de outro engenheiros e cientistas com excelente formação, mas que ainda não estão conversando. A ausência de diálogo e repertório convenhamos que para um país de dimensões continentais como o Brasil é possível contar nos dedos o número de instituições e festivais empenhados em divulgação de arte e cultura digital - acaba por alimentar matérias sensacionalistas sobre as iniciativas na área, como a matéria do jornalista Silas Martí, na Folha de S. Paulo: 
É a segregação que se vê hoje entre "tecnófilos" e "tecnófobos", nas palavras de Daniela Bousso, diretora do MIS. O fato de artistas em novas mídias trabalharem mais com algoritmos do que pincéis acabou criando um gueto na área - a arte digital não se considera parte das artes visuais e reivindica espaço próprio em editais e até dentro do Ministério da Cultura, que estuda criar um colegiado só para o setor.

"Isso é humano, procurar seus iguais", diz Patrícia Canetti, eleita representante das novas mídias nas discussões do MinC. "O gueto tem que existir, é como você se fortalece"

Martí, 2009, p. E8

Criticamos muito pouco o pouco que produzimos, mas criticar sem procurar conhecer também não é o caminho. Difícil dar credibilidade a uma matéria que ainda considera a tecnologia digital como uma "nova mídia" e que se fundamenta em dualismos preconceituosos, opondo tecnófilos e tecnófobos. Talvez o jornalista Silas Martí seja um entre aqueles que ainda não perceberam que a riqueza da produção de Arte Eletrônica contemporânea está justamente nos diálogos e não a mera superação histórica do momento que nos antecedeu.

\subsection{Considerações}

Com base da teoria Cibernética de Segunda Ordem, procuramos evidenciar neste capítulo os processos colaborativos pelos quais se desenvolvem a produção de Arte Eletrônica, sua fundamentação nos aspectos comunicacionais, eminentemente recursivos e estruturados na rica tensão entre acidentes e programas. A partir de nossos exemplos e da estruturação teórica, procuramos esboçar de que maneira a noção de criatividade se modifica frente à cultura eletrônico-digital.

No capítulo 3, olhand o para o nosso percurso investigativo, desenvolvemos a ideia de como esses processos podem se constituir como Espaços de Conhecimento. A discussão é uma maneira de criar argumentos que sirvam a outros campos do saber no entendimento das questões emergentes nos processos criativos e executivos da Media Art, contribuindo para que possam se reinventar frente à cultura digital. 



\section{O3 META-CRÍTICA: ARQUITETURA E SÍNTESE DO CONHECIMENTO}

Neste capítulo, cujo objetivo é começar a sintetizar nossas colocações, continuamos o processo de auto-crítica, pondo em discussão as dimensões invisíveis dos processos de investigação e criação, coincidentes em nosso caso. Em seguida esboçamos de que maneira os processos da Media Art podem ser observados enquanto processos de construção de Espaços de Conhecimento, finalizando com proposições de referências para os processos no campo da Arquitetura. Finalizando, assumimos o caráter utópico de nossos anseios.

\subsection{A crítica da crítica: dimensões do invisível}

Para o desenvolvimento da crítica, atravessaremos as dimensões invisíveis do processo de pesquisa e experimentação em que nos envolvemos, iniciando com a explicitação do movimento de imersão e distanciamento a que nos submetemos, passando pela exploração do conceito cibernético da caixapreta, até chegarmos à discussão sobre os processos invisíveis que envolvem a produção de Media Art.

\subsubsection{Imersão e distanciamento}

A metodologia empregada para a construção de nosso modelo sobre o universo de produção da Arte Eletrônica é baseada num processo elástico de imersão e distanciamento. Mergulhamos neste universo através de referencias bibliográficas, contato com personagens do cenário analisado eexperimentamos praticamente o processo criativo de uma instalação interativa.

A opção por incorporar o próprio processo na análise sobre o tema dialoga com os princípios da Cibernética de Segunda Ordem, que considera o papel do observador no sistema em observação. No contexto da crise da objetividade da Ciência, nossa postura pretende participar do movimento de se

levar ao nível da consciência tal ligação subterrânea que sempre tem unido ciência e arte. Tal ligação ininterrupta entre vivência e conhecimento deve ser conscientizada, se quisermos ter vivências e conhecimentos plenamente humanos, isto é: políticos, intersubjetivos. 
Para o teólogo e filósofo francês Pierre Teilhard de Chardin, "objecto e sujeito aliam-se mùtuamente no ato de conhecimento" e "coincidindo o ponto de vista subjectivo com uma distribuição objetiva das coisas, a percepção estabelece-se na sua plenitude. (...) Tal parece ser o privilégio do conhecimento humano" (Chardin, 1965, p.7).

Não somente no âmbito científico são construídos modelos levando em consideração os sujeitos no processo/sistema observado. Na literatura, por exemplo, Umberto Eco em "Seis passeios pelos bosques da ficção"(1994), desenvolve a noção de autor e leitor modelos: "numa história, sempre há um leitor, e esse leitor é um ingrediente fundamental não só do processo de contar uma história, como também da própria história" (Eco, 1994, p.07). ĺtalo Calvino, em diálogo com Eco, define leitor e espectador-modelos como "uma espécie de tipo ideal que o texto não só prevê como colaborador, mas ainda procura criar" (Calvino apud Eco, 1994, p.15). Essas construções de relações entre obra e fruidor, como espécie de "protocolos ficcionais" (Eco, 1994) são a base da troca de conhecimento como já demonstravam os diálogos platônicos. O "leitor-modelo" vislumbrado pelo "escritormodelo" - e estende-se essa ideia aos artistas e fruidores em geral - é alguém que está pronto pra jogar, assim que são conhecidas as regras do jogo (Eco, 1994). Para complementar e reforçar essa antiga qualidade lúdica da relação entre obra e fruidor, nos remetemos às palavras do filósofo neerlandês Johan Huizinga:

O elemento lúdico é de tal modo inerente à poesia, todas as formas de expressão poética estão de tal modo ligadas à estrutura do jogo, que é forçoso reconhecer entre ambos a existência de um laço indissolúvel.

Huizinga, 2000, p.177

É precisamente no infinito jogo lúdico e dialógico que reside a interatividade entre artistas, obras e público na cultura eletrônico-digital. Trouxemos a Teoria Conversacional de Gordon Pask no capítulo dois justamente para pontuar que a interatividade criativa da Media Art está nesse jogo, e não no potencial reativo de um dado sistema de uma instalação interativa.

No jogo entre obra e fruidor, também vale lembrar as observações de Umberto Eco sobre a forte tendência humana em trocar a ficção pela vida e a vida pela ficção, uma vez que os mundos ficcionais são tão "pequenos e ilusoriamente confortáveis", ou mesmo, assustadores. Por diversas vezes na história da humanidade assistimos a regimes totalitários se valeram do potencial de imersão das artes e dos meios de comunicação para construírem seus pilares (Weibel, 2005). Por isso, como tendência oposta ao potencial alienante da imersão, surgem recursos de linguagem nas artes, em todos os seus suportes, a fim de promover 
o distanciamento crítico, que é uma das chaves para a construção de Espaços de Conhecimento. Essa postura é a mesma que Flusser assume, ao afirmar que, em oposição à dispersão do movimento entrópico do universo, era preciso afastar-se do divertimento para observá-lo de fora, a fim de desenvolvermos um distanciamento crítico (Flusser, 2008, p. 88-9).

Já que o homem tanto aprecia as confusões entre ficção e realidade, por que então não nos esforçamos na criação de universos ficcionais tão complexos e contraditórios como a vida real? (Eco, 1994, p. 123).

A estética da "obra aberta" proposta por Eco nos incita à fruição, à elaboração e à crítica de obras que se esforçam para ser tão ambíguas quanto a vida, misturando e relativizando aspectos de diferentes tempos e incluindo as confusões entre realidade, imaginação e subjetividade (Eco, 1994, p. 123). Tais preocupações oriundas do universo literário nos servem como referência nos processos criativos da Media Art para que, mesmo imersos num universo pelo qual somos apaixonados, possamos também ter espaço para a abertura de significação e distanciamento crítico.

Uma proposição mais pragmática, mas também a ser considerada em nosso modelo de pesquisa e produção de conhecimento baseada na imersão e no distanciamento, é a "Theory U", desenvolvida pelo pesquisador Otto Scharmer do MIT. Engajado em desenvolver inovações no âmbito da aprendizagem e liderança, Scharmer afirma que o processo de ativação dos níveis mais profundos da liderança e aprendizagem envolve três movimentos. O primeiro consiste em observar, abrir e ligar-se ao que está acontecendo lá fora. O segundo está em permitir que o conhecimento interior surja: abrir e ligar-se ao que está emergindo de dentro. E o terceiro é atuar em um instante: trazer o novo para a realidade como ela deseja. (Scharmer, 2006). Esses três movimentos são esquematizados pelo autor no formato da letra U, que dá nome à sua teoria: "Theory U".

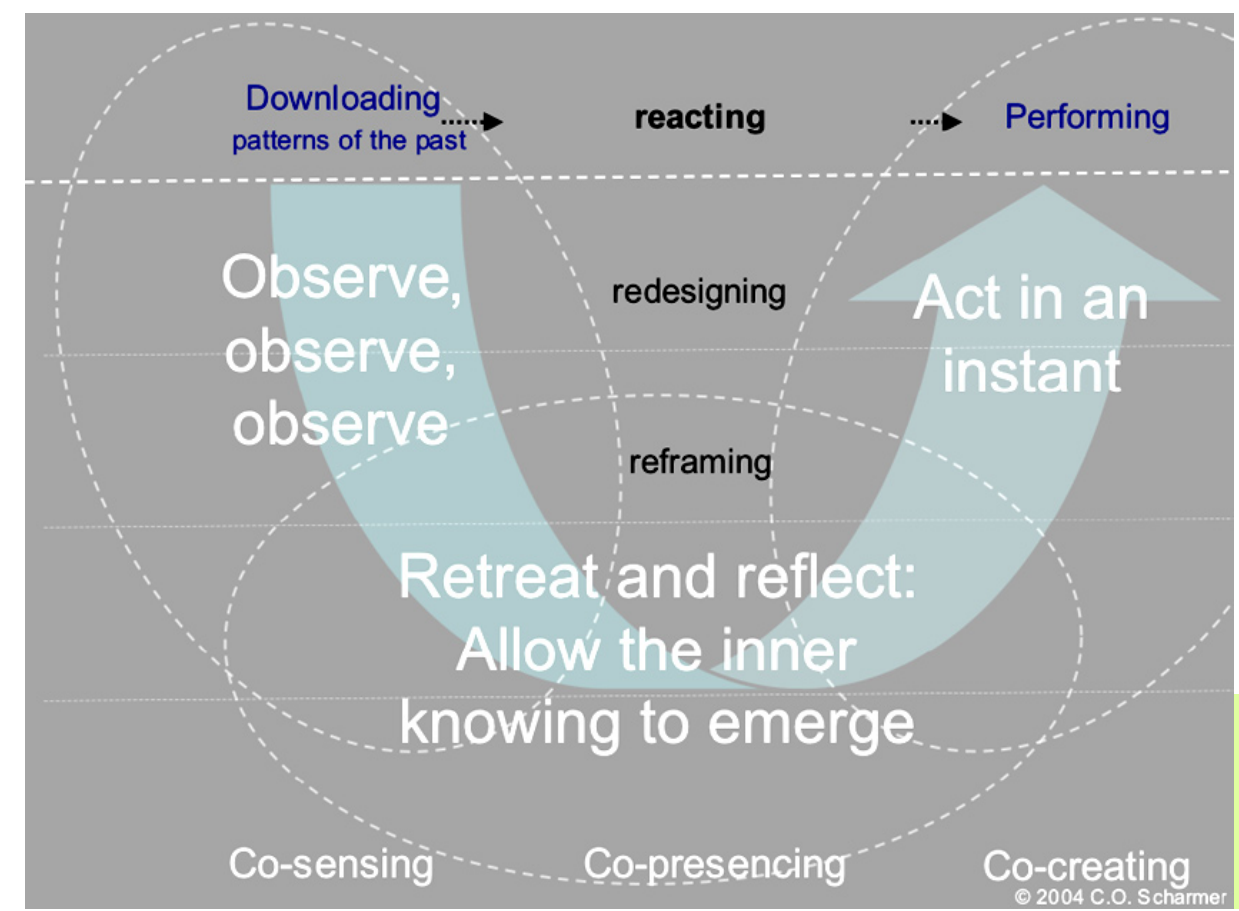

Figura 3.1: Esquema de Otto Scharmer da "Theory U". Fonte: Schamer (2006, website). 
Scharmer nesta mesma teoria afirma que para acessar os níveis mais profundos de aprendizagem e de inteligência coletiva, os líderes precisam de novas tecnologias sociais que ativem e abram três instâncias: mente, coração e desejo (Scharmer, 2006). Para isso Scharmer propõe algumas sub-etapas para as ações, demonstradas no diagrama a seguir:

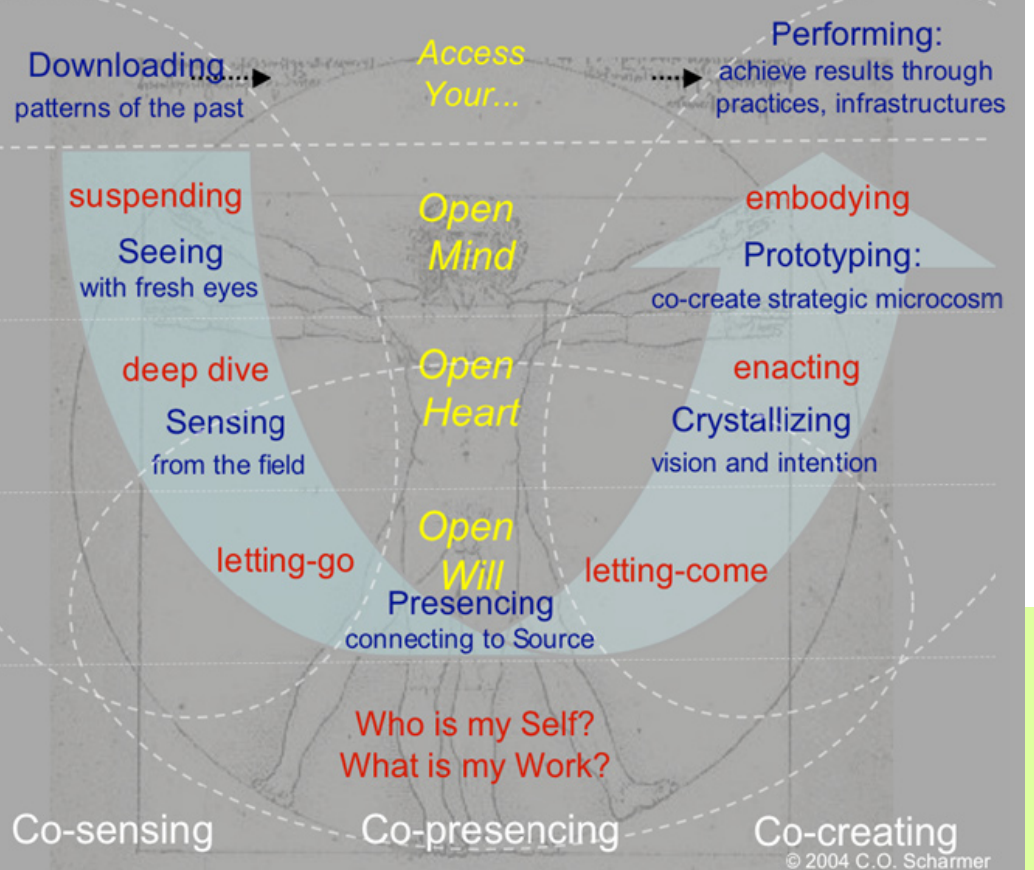

Figura 3.2:

Detalhamento

esquemático da

"Theory U". Fonte:

Scharmer (2006, website).

No contexto de nossa pesquisa, talvez tenhamos atravessado essas etapas intuitiva e naturalmente em relação ao nosso objeto de análise, performando finalmente na redação deste trabalho.

A seguir trataremos do nosso processo de imersão e distanciamento em nosso objeto de pesquisa à luz do conceito cibernético da Caixa-preta.

\subsubsection{Caixa-preta}

O assunto das “"caixas-pretas"] já foi tangenciado por autores como Vilém Flusser em "A Filosofia da Caixa Preta"(1983) e Roland Barthes em "A câmara clara"(1980) quando estes discutiam filosofia e linguagem da fotografia. Essas publicações, junto à "A obra de arte na era de sua reprodutibilidade técnica" (1993) de Walter Benjamin, se constituem como marcos históricos no percurso maquínico das artes.

Segundo Flusser, a grande característica da atual revolução cultural é o fato dos participantes da cultura ignorarem o interior das caixas-pretas que manipulam. Em momento anterior, a situação cultural demandava aos participantes da cultura o aprendizado (ler, escrever, desenhar, etc.). Para o autor, a situação cultural emergente desconsidera a aprendizagem e se 
apóia na programação de seus participantes, deixando os problemas técnicos delegados aos especialistas, que resolverão os problemas, previamente formulados para serem resolvidos. "O desprezo pela técnica que sustenta a nova situação cultural está inscrito no seu programa" (Flusser, 2008, p. 84).

No entanto, o desprezo pela técnica e a delegação dos problemas técnicos aos especialistas pode ser uma postura que exclui o especialista enquanto participante criativo - na emergência de um novo tipo de consciência, póshistórica, a ação técnica também é uma ação criativa.

Para os Ciberneticistas, a citar Ross Ashby e Gordon Pask(1973), que possuem o olhar voltado ao fluxo de informações entre as partes envolvidas, as caixas-pretas são concebidas como sendo alimentadas por conteúdos provid os pelos diferentes colaboradores envolvidos no processo comunicacional (Pratschke, 2008, p.6-7). De acordo com este modelo, as caixas pretas sempre existirão. Elas correspondem às partes que os sujeitos não entendem e não precisam entender, pois não envolvem diretamente o objeto de seu interesse.

Em uma publicação somente destinada à elucidação do famigerado conceito cibernético da caixa-preta, Glanville, a descreve da seguinte maneira:

Nossa Caixa-preta não é um objeto físico, mas um conceito
(um fantasma) que usamos para desenvolver o que Bateson
chama de princípio explicativo, que nós evocamos quando
estamos em face de uma confusão incerta. Ela não tem
substância, e então não pode ser aberta, e nem contem um
interior. Sua função é permitir a criação de uma explicação de
um comportamento observado e algum objeto/mecanismo
que parece gerar aquilo sobre o qual estamos incertos. É a
invenção do observador
Glanville, 2009, p.154, tradução nossa56

Além de atestar a natureza ficcional da caixa-preta, Glanville reitera a interdependência e a recursividade da relação entre a caixa-preta e o observador, o que ele chamou de princípio da reciprocidade mútua. O observador é tão obscuro para a caixa-preta quanto ela o é para o observador.

No entanto, a obscuridade conceitual da caixa-preta incita o questionamento da possibilidade em "branqueá-la". Nós agimos como se houvesse a possibilidade do branqueamento. (Glanville, 2009). Quando estamos

\footnotetext{
56 Do original: "our Black Box is not a physical object, but a concept (a phantasm) we use in order to develop what Bateson calls an explanatory principle, which we evoke when we are faced with an uncertain confusion. It has no substance, and so can neither be opened, nor does it have an inside. Its function is to allow the creation of an explanation of some observed behaviour and any object/mechanism that seems to generate this about which we are uncertain. It is the invention of the observer" (Glanville, 2009, p.154).
} 

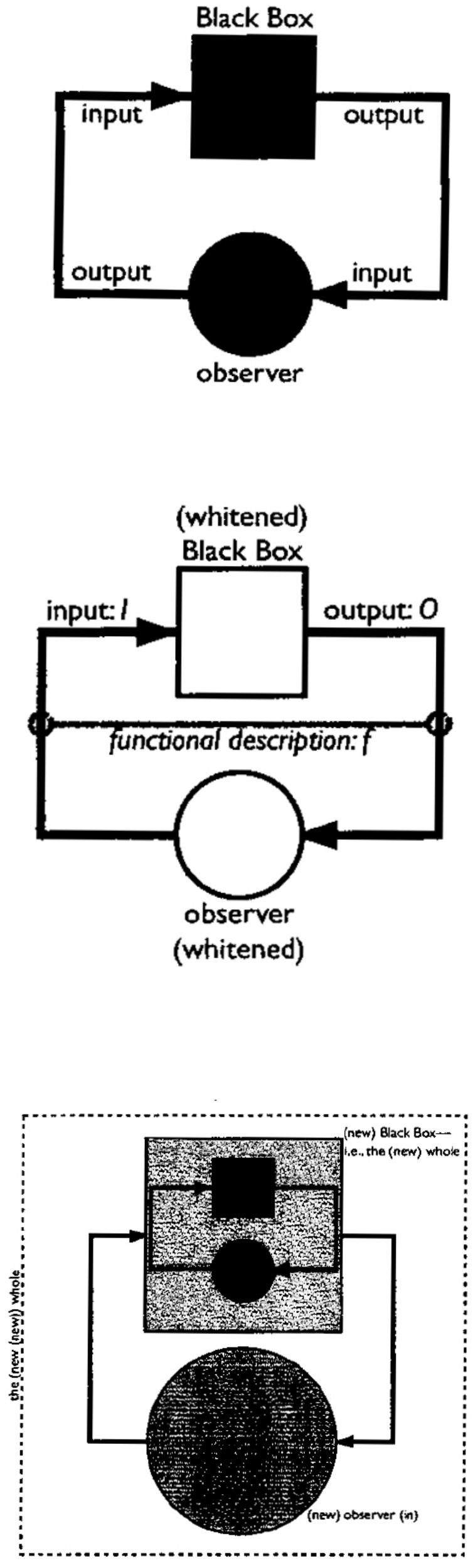

Figura 3.3: Esquematização de Ranulph Glanville para demonstrar a circularidade entre a caixa-preta e o observador (investigador). Fonte: Glanville (2009, p. 159).
Figura 3.4: Esquematização de Ranulph Glanville para demonstrar a circularidade entre a caixa-preta e o observador (investigador), com ênfase na descrição funcional delineada pelo observador/investigador e na abertura/ branqueamento das duas instâncias: caixa e observador. Fonte: Glanville (2009, p. 162).
Figura 3.5: Esquematização de Ranulph Glanville para demonstrar a circularidade entre a caixa-preta e o observador (investigador), com ênfase na possibilidade de um segundo (e infinitos) níveis de recursão do ato de se observar observador e caixa-preta. Fonte: Glanville (2009, p. 164). 
seguros de que a viabilidade de nossa descrição funcional dos mecanismos da caixa-preta chegou muito próximo do que estamos considerando como verdade, acreditamos ter entrado num processo de branqueamento da caixapreta.

Mas Glanville na seqüência coloca:

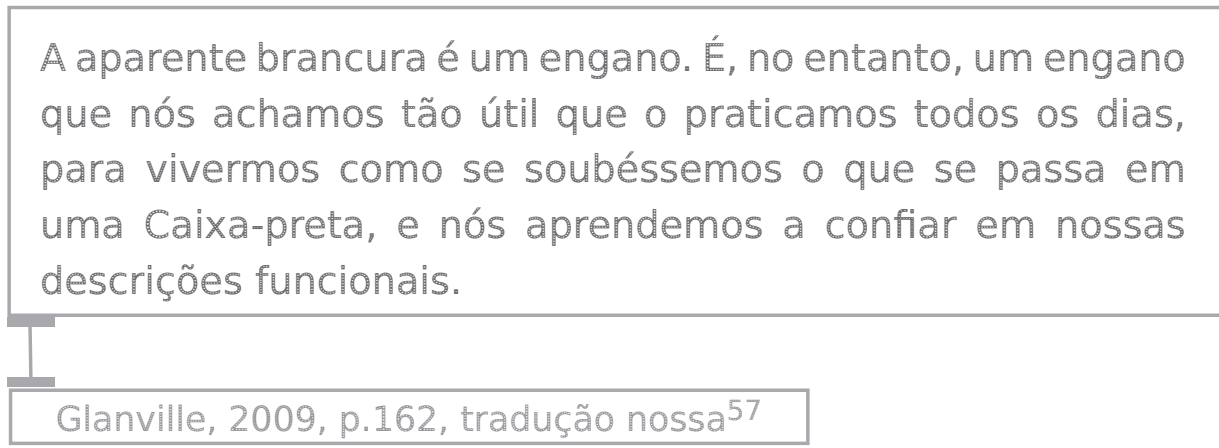

Colocar que nossas descrições funcionais são meramente invenções enganosas para nós mesmos e que as tornamos como verdade por conveniência é um pouco desanimador frente aos esforços humanos em tentar desvendar (e controlar) o mundo circundante. Como uma alternativa à aparente não solução da funcionalidade da caixa-preta, Glanville nos aponta a possibilidade de uma segunda camada de recursão no processo de se observar as interações entre observador e caixa-preta:

através de transcendência das fronteiras, onde eu, como
observador, crio uma recursão em que estou tanto como
observador da circularidade com a Caixa-preta, como um
observador do sistema/conjunto, entendido no todo como
uma Caixa-preta. Aqui, os comportamentos que considero são
aqueles que me incluem, portanto, são os comportamentos
do sistema/conjunto, que observo. Esta é uma forma de levar
em conta o meu envolvimento na observação, sem ter que
ficar de fora.

Glanville, 2009, p.165, tradução nossa58

\footnotetext{
57 Trecho original:" The apparent whiteness is a deceit. It is, however, a deceit we find so useful that we practice it every day, for we do live as though we know what happens in a Black Box, and we do learn to trust our functional descriptions"(Glanville, 2009, p.162).

58 Excerto original: "through transcending the boundaries, where I, as observer, create a recursion in which I am both the observer in the circularity with the Black Box, and an observer of the whole/system, itself understood as a Black Box. Here the behaviours I consider are those that include me, so they are the behaviours of the whole/system, observed. This is a way of accounting for my involvement in the observing, without having to stand outside" (Glanville, 2009, p.165).
} 
Aberta essa possibilidade de recursão infinita, Glanville coloca que dessa forma, pode emergir um valor fixo, uma constante. Essa constante seria mais uma vez a tentativa de se criar uma pseudo-objetividade da experiência, como se realmente existisse algo exterior que existe independente de nós (Glanville, 2009).

Assim, na Cibernética de Segunda Ordem, trazida neste momento através do pensamento de Glanville, a caixa-preta é vista em perspectiva diferente à flusseriana, e se constitui como um constructo (ficcional) aplicado por um observador no local de alguma mudança percebida no local observado.

A inserção de uma caixa-preta permite uma descrição da observação ser desenvolvida para o que poderia explicar mudanças observadas e ainda por serem observadas, através da interação do observador com sua caixa-preta.

Glanville, 2001, p.2, tradução nossa 59

Glanville acrescenta à definição que muitos usuários das caixas-pretas se esquecem da sua natureza ficcional, e devem assumir que tal mecanismo de descrição/explicação é algo que a caixa-preta por si só não pode revelar (Glanville, 2001).

A seguir tentaremos sintetizar o conceito do uso da caixa-preta em nosso processo investigativo sobre o campo de atuação da Media Art.

\subsubsection{Media art, processos invisíveis e "uma história que não quer ser contada"}

Para Oliver Grau, enquanto uma arte eminentemente virtual e nãolocalizável, a Arte Eletrônica forma uma "imagem espacial comemorativa imaginária" e através da capacidade de "transporte de informações complexas e concentradas", ela pode conduzir à construção de uma espécie de "espaço de pensamento", tecnicamente imaterial e concentradamente composto de informações sem continuidade linear, mas com o objetivo definido de formar e instruir o visitante/interator (Grau, 2007, p.266). Com a abordagem de formação do visitante, diversas obras de Arte Eletrônica lidam com elementos históricos somados a elementos e fatos recentes através de aplicações disponibilizadas pela cultura eletrônico-digital, proporcionando por meio da produção de um continuum, o acesso à história e à cultura da civilização humana.

Nosso esforço na construção do modelo apresentado neste trabalho se concentrou na tentativa de elucidar informações sobre processos de criação, mais

59 Excerto original: "The insertion of a Black Box allows a description to be developed for what might account for observed and yet-to-be observed changes, though the interaction of the observer and his Black Box"(Glanville, 2001, p.2). 
do que objetos ou instalações artísticos. Durante nossa investigação, a medida que coletamos dados sobre os processos de outros artistas, concomitante ao nosso próprio processo, geramos uma recursão como aquela descrita por Glanville. É possível vislumbrar nossa experiência dentro dos modelos de recursão da caixapreta apresentada pelo autor.

Para exemplificar, cabe citar nossa identificação com o relato dos integrantes do Laboratório de Luz60, da Universidade Politécnica de Valência, Espanha. As pesquisadoras e artistas Dolo Piqueras e Maria José Martinez de Pison, durante a entrevista realizada, descreveram seus processos de trabalho como processos totalmente invisíveis. Segundo elas, o processo de criação e execução na área de Media Art, por ser aberto e baseado em constantes e inúmeros testes, é um processo de aprendizagem bastante lento e, em certa medida, invisível. Piqueras afirma que durante o processo criativo, nós aprendemos sem estarmos conscientes de que estamos aprendendo61. Durante a trajetória facilmente nos desesperamos porque os dias passam, são feitos inúmeros testes repetidas vezes, e não se tem nada físico realmente funcionando. Após certo distanciamento da experiência percebemos que aprendemos muito durante todas as etapas do processo (Piqueras; Pison, 2008).

Em nosso distanciamento crítico, à medida que manipulamos nossa caixapreta (os processos de produção da Arte Eletrônica), também nos observamos interagindo, porque simultaneamente analisamos os conteúdos indiretos que captamos, e realizamos um processo de experimentação estética. Citando o esquema feito por Glanville e apresentado acima, objetivamos nosso pensamento na seguinte forma:

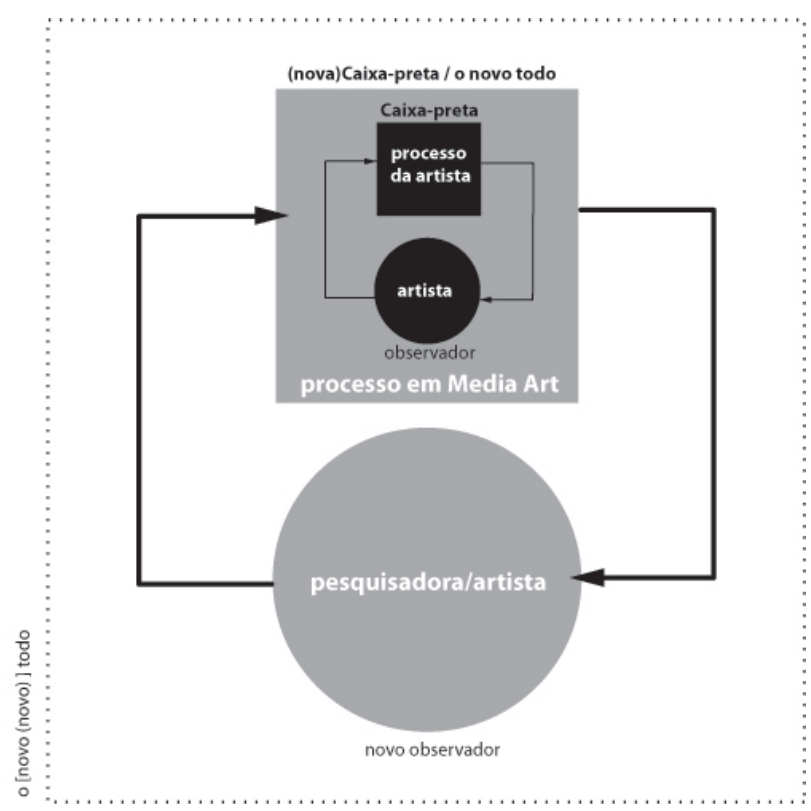

Figura 3.6: A artista Dolo Piqueras descreve seu processo de criação. Nós observmos nosso próprio processo, do qual ela também faz parte. Fonte: Lautenschlaeger (2009).

60 Entrevista realizada por nós no Interface Culture Department da Kunstuniversität Linz, Áustria, em 10set2008.

61 Trecho extraído da entrevista: “you are learning but you are not conscientious that you are learning. So sometimes you got exasperated because you feel like you passing the days and you are not learning anything, but you are really learning"(Piqueras; Pison, 2008). 
Pronto. Está parcial e funcionalmente descrito o modelo recursivo de nossas relações enquanto pesquisadores (observador) com nosso tema de pesquisa (caixa-preta), os processos de produção da Media Art contemporânea. Essa descrição é tão conveniente quanto necessária em diversas instâncias, acadêmicas ou mercadológicas, por exemplo.

Os aspectos recursivos do processo de criação e de aprendizado das interfaces dos trabalhos de Media Art, evidenciadas em vários dos exemplos ao longo de nosso trabalho - e recolocado neste momento através das repetições de testes constantes e da questão da invisibilidade - não se aplicam por sua vez no âmbito da criação das interfaces amigáveis oferecidas pelo mercado.

Como aponta Aart Bijl, pelas regras do mercado, as relações entre usuários e desenvolvedores tendem a ser unilaterais. Desenvolvedores alternativos por sua vez, tendem a estabelecer mais trocas com as pessoas de outras etapas de produção (Bijl, 1995, p.12-13), fazendo as idas e vindas dos processos coletivos de criação, enquanto processos potencialmente recursivos, a favor do compartilhamento de informações, experiências e conhecimento. A contraposição dos dois diferentes processos foi esquematizada por Bijl nos dois esquemas a seguir:

\section{'USER-FRIENDLY' TOOLS}
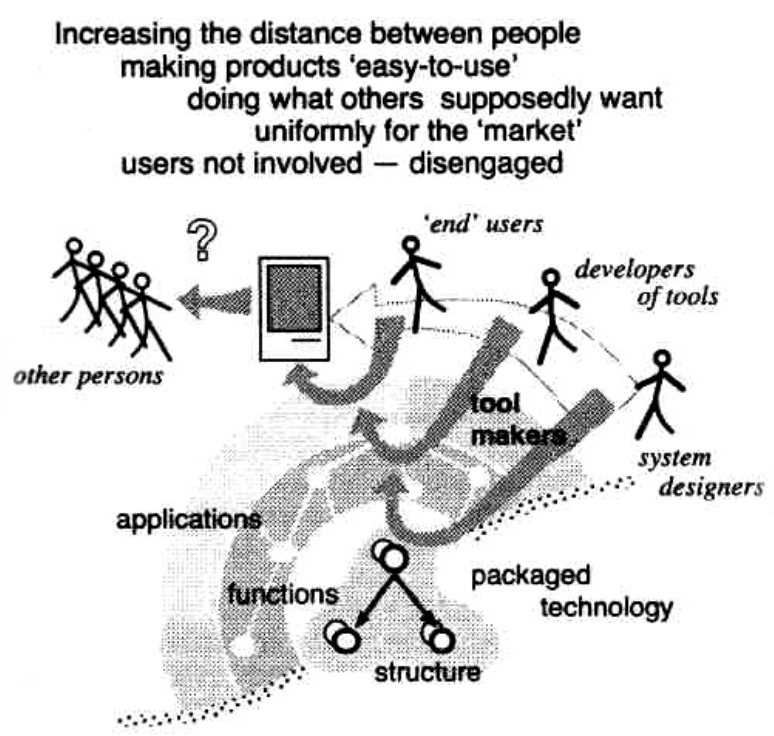

\section{PLAYERS} IN PRACTICE
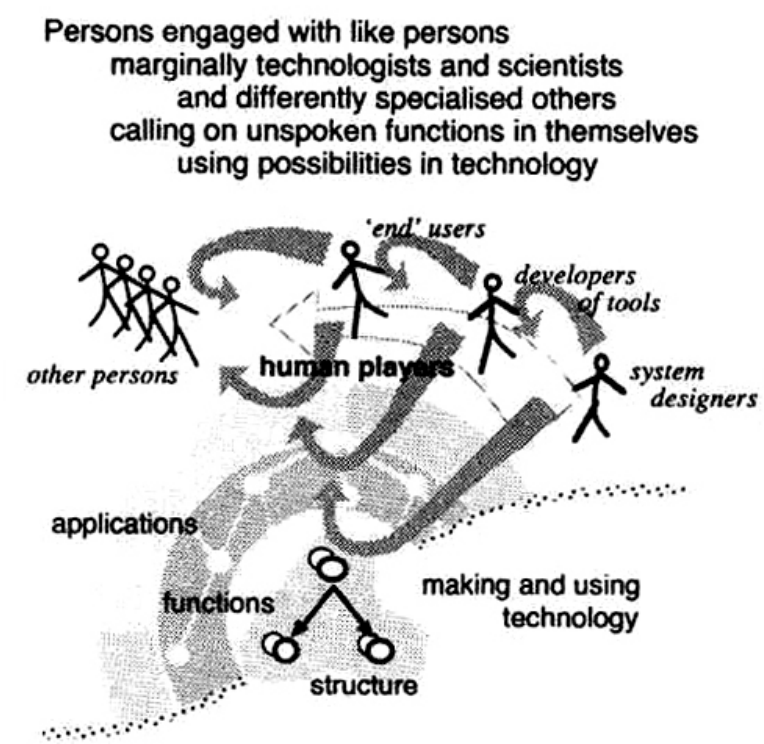

Figura 3.7: Ferramentas amigáveis: processos unidirecionais. Figura 3.8: Jogadores em prática: processos recursivos. Fonte: Bijl (1995, p.12-13)

O fato de Aart Bijl ter identificado que os processos de criação das interfaces amigáveis que o mercado tem oferecido se diferenciam dos processos de criação das interfaces de projetos em Media Arté substancial para nós. Não podemos negar que de certa forma, a invisibilidade da técnica das interfaces amigáveis que o mercado vem ofertando (e a academia tem estudado como 
computação ubíqua) também penetra na produção de Media Art pela vontade de naturalização das interfaces tangíveis inseridas no espaço público. No entanto, essa absorção sem o questionamento se faz um tanto quanto polêmica na área de Arte Eletrônica. Essa não-transparência (ou invisibilidade) da técnica não teria o mesmo efeito alienador que o histórico recurso da imersão possui?

Difícil responder prontamente a esta pergunta, e também respondê-la agora está fora do escopo de nossa pesquisa. Mas suspeitamos que um olhar atento às diferentes maneiras de lidar com as caixas-pretas, conforme nos demonstra Glanville, é um passo importante no entendimento deste assunto.

A seguir, nos debruçamos a elucidar como as práticas colaborativas da produção de Arte Eletrônica podem se constituir enquanto Espaços de conhecimento.

\subsection{Construindo Espaços de Conhecimento}

\subsubsection{Definições}

Uma das referências que serviram de inspiração para a discussão sobre o tema "Espaços de Conhecimento" a partir de produções em Media Art, foi o capítulo homônimo do livro "Arte virtual: da ilusão à imersão", de Oliver Grau. Neste capítulo, o autor descreve diferentes trabalhos de arte eletrônica, realizados por diferentes grupos, cuja intenção foi a criação de um espaço que possibilitasse ações, ideias e pensamentos, e onde conceitos divergentes pudessem ser colocados em discussão (Grau, 2007, p.241). Na modelação de nosso argumento, relacionamos a abordagem de Grau com a emergência do assunto em algumas das entrevistas realizadas junto a pesquisadores, artistas e curadores da área de Media Art.

A noção de Espaços de Conhecimento trazida para discussão é derivada de nossa compreensão sobre os processos de criação colaborativos e, para melhor delineá-la pressupomos algumas principais características, apresentados a seguir.

Sabemos que a produção de conhecimento é algo essencialmente humano, que nasce a partir da curiosidade e da inventividade do homem e se espalha na medida em que os sujeitos se relacionam. Embora nos dicionários as definições de termos como "conhecer" ou "conhecimento" pressuponham a noção de apreensão do mundo e das coisas através da experiência e da razão, enquanto atos indissociáveis das atividades perceptivas humanas; nossa tradição aristotélica nos condicionou a pré-conceber o termo "conhecimento" como algo adquirido essencialmente através do intelecto.

Em contrapartida a esta tradição, a nossa abordagem prevê a noção de 
Espaço do Conhecimento como uma possibilidade de reinvenção do laço social, baseado no aprendizado recíproco, na sinergia das competências, na imaginação e nas inteligências coletivas, ou seja, em nossa capacidade em trabalhar em comum acordo ou, mais desafiadoramente, nos entendermos com o inimigo (Lévy, 1998).

Em entrevista com o artista e pesquisador austríaco Dietmar Offenhuber62, cujo foco de trabalho nos últimos anos tem sido a visualização de informação e conhecimento, ele afirma que dentro do campo da visualização de informação existe uma gama de disciplinas. Segundo Offenhuber (2008), a ideia de visualização do conhecimento lida com estruturas e espaços semânticos, onde são empregados signos e significados na disposição espacial dos elementos em determinada estrutura, como em ontologias.

A abordagem de Offenhuber é complementar ao argumento do segundo capítulo, pois relaciona o conhecimento com processos comunicacionais, os quais são basicamente fundamentados em signos e significações. Para o filósofo Pierre Lévy, toda atividade ou ato de comunicação, toda relação humana implica um aprendizado. Pelas competências e conhecimentos que envolve, um percurso de vida pode alimentar circuitos de troca e de saber (Lévy, 1998, p. 27). É nesta perspectiva dialógica que argumentamos que os processos coletivos de criação em Media Art se constituem como Espaços de Conhecimento.

Também abordado na área da psicologia matemática, o conceito de Espaços de Conhecimento foi mencionado pela primeira vez no início dos anos 1980 por Jean-Paul Doignon e Jean-Claude Falmagne, quando estes se lançaram em estudar matematicamente o acesso ao conhecimento. A abordagem, que atravessa a teoria dos conjuntos, diz que a existência de um indivíduo que sabe $X$ e outro que sabe $Y$ num mesmo grupo, com o passar do tempo, ambos saberão $X Y$ e a evolução do domínio de um dado conhecimento evolui segundo o diagrama a seguir (Doignon; Falmagne, 1999, p.04):

Figura 3.9: Imagem esquemática de uma estrutura de conhecimento. Fonte: Doignon e Falmagne (1999, p.04).

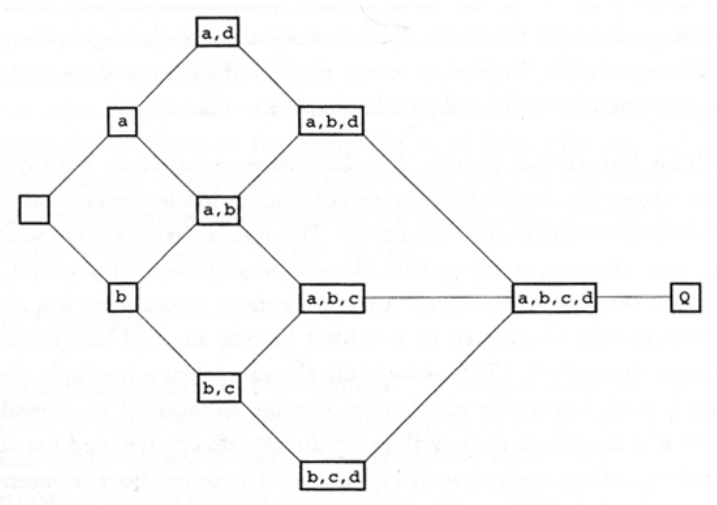

Fig. 0.1. The knowledge structure of Equation (1).

The graph in Figure 0.1 represents the knowledge structure

$\mathcal{K}=\{\varnothing,\{a\},\{b\},\{a, b\},\{a, d\},\{b, c\},\{a, b, c\}$, $\{a, b, d\},\{b, c, d\},\{a, b, c, d\}, Q\}$.
(1)

62 Entrevista realizada com Dietmar Offenhuber em 21/Maio/2008 em Linz, Áustria. Offenhuber é arquiteto pela TU Vienna, com experiência na área de espaços virtuais e espaços do conhecimento comparados a estruturas físicas. É um dos membros fundadores do Ars Electronica Future Lab onde adquiriu experiência na concepção e execução de exposições interativas. Realizou mestrado na área de Media Art and Sciences pelo MIT Media Lab. 
A nossa intenção ao introduzir a referência à psicologia matemática não se trata de apresentar qualquer fórmula que prove a existência de Espaços de Conhecimento; mas, antes de tudo, chamar a atenção para o interesse transdisciplinar em relação ao assunto. Essa abordagem matemática do Espaço de Conhecimento traduz a mesma perspectiva filosófica deste trabalho, cujo entendimento não se limita ao conhecimento especifico científico, mas daquele que caracteriza e impulsiona a espécie humana de maneira geral. A atividade humana de organizar e reorganizar suas relações com os outros, com os signos e as coisas, com o universo e, sobretudo consigo mesmo, envolve o homem em processos de conhecimento e aprendizado.

Assim, retomando Lévy, o que nomeamos aqui de Espaços de Conhecimento está relacionado com um "saber" co-extensivo à vida, que

tem a ver com um espaço cosmopolita e sem fronteiras de relações e de qualidades; um espaço da metamorfose das relações e do surgimento das maneiras de ser; um espaço em que se unem os processos de subjetivação individuais e coletivos.

Lévy, 1998, p.121

Comesta abordagem, vislumbramosqueopensamento nãoestá enclausurado em discursos racionais e que também há espaço para "pensamentos-corpo, pensamentos-afeto, pensamentos-percepção, pensamentos-signo, pensamentosconceito, pensamentos-gesto, pensamentos-máquina, pensamentos-mundo" (Lévy, 1998, p.121). A abertura para essas possibilidades dá vazão à construção de Espaços de Conhecimento que ganham vida através de devires individuais e coletivos, em constante e dinâmica reconfiguração.

\subsubsection{Cibernética, conhecimento e aprendizagem}

Nos estudos cibernéticos, em complemento à proposição da “dança da conversação", podemos citar o trabalho dos neuro-cientistas chilenos Francisco Varella e Humberto Maturana, que juntos escreveram “The Tree of Knowledge", uma compreensão da epistemologia e cognição baseada numa bio-cibernética(Glanville, 2001).

Apesar de relações biológicas envolvidas nessa vertente de teoria do conhecimento, nos interessam as relações éticas que ela nos traz. A teoria cibernética do Conhecimento, coloca a ética como própria e interna ao observador; e não como algo externo, um dado da realidade(Glanville, 2001). 
Os estudos da Cibernética acerca da caixa-preta também se constituem como uma perspectiva para se divagar sobre os processos de conhecimento. A descrição funcional do sentido que se atribui ao comportamento derivado e existente na interação entre o observador e a caixa-preta pode ser interpretada como uma forma de teste. Segundo Glanville, este é um posicionamento muito próximo ao do filósofo da ciência austríaco e naturalizado britânico Karl Popper. E, a possibilidade da recursão seqüencial conduzir a um valor constante e, portanto, a uma pseudo-objetividade, Glanville demonstrou como discussão similar à de Piaget (1955), quando este discute a constância ou conservação dos objetos.

Retomando Pask, ele sintetiza bem as relações entre a nossa necessidade de controle, nossos processos de aprendizagem e os processos colaborativos. Para o autor, no domínio simbólico, a noção de "controle" é globalmente equivalente a "resolver problemas", mas também pode ser entendido como "chegar a um acordo com", "explicar" ou ainda, "relacionar a um corpo existente de experiência". Além disso, para aprender a "controlar" ou "resolver os problemas", necessariamente conceituamos e abstraímos. Em função disso, o ambiente humano é interpretado em vários níveis em uma hierarquia de abstração (letras, palavras, frases gramaticais, afirmações com significado, textos, etc.). Esta tendência é a raiz da curiosidade e da assimilação do conhecimento e nos impelem a explorar, descobrir, explicar e animar nosso entorno. Ao nos dirigirmos ao ambiente social de outros homens, nos colocamos em comunicação social, conversas e outras formas de interação e colaboração (Pask, 1968).

Conforme identificamos no capítulo 2 em relação aos processos criativos colaborativos de obras de Arte Eletrônica, a coordenação do design transdisciplinar pode também ser modelada como um controle distribuído de aprendizagem. A ação da mudança realizada por cada agente é, em essência, uma ação de controle que tenta guiar o mundo para um estado que corresponde tanto aos objetivos e crenças individuais, como às restrições específicas e globais. Objetivos e crenças são criados e recriados pelos sujeitos com base no conhecimento que possuem e constroem sobre o mundo, seus modelos de referência. Através da observação e da aprendizagem concretizadas a partir das associações entre ação e efeito, os sujeitos obtém o material para descobrir as ações de controle mais adequadas a serem tomadas durante os processos que coordenam (Alexiou; Zamenopoulos, 2007).

Para Alexiou e Zamenopoulos, existem diferentes mecanismos para se atingir o aprendizado. Um deles pode ocorrer quando as crenças e os objetivos dos agentes são reforçados no contexto em que operam. Outro se dá quando condições contextuais que levam à ação são mantidas ou reproduzidas. Ou ainda, através de reforço emocional, quando possíveis metas são 'pré-selecionadas' por causa das reações emocionais aprendidas para cenários futuros antecipados 
(Alexiou; Zamenopoulos, 2007, p.592). Para os mesmos autores, adaptação e aprendizagem, não só são considerados como ferramentas importantes para melhorar a capacidade individual dos agentes, mas também para alcançar um nível comum de entendimento e acordo (Alexiou; Zamenopoulos, 2007, p.588).

Com base nestas colocações, consideramos que tanto na esfera individual (micro) como na coletiva (macro), aprendizagem e conhecimento emergem a partir da experimentação de diferentes combinações de inputs e outputs das caixaspretas que manipulamos. E nos parece um mecanismo apropriado para relacionar as ações pessoais intencionais com a representação das funções sociais, como uma espécie de aprendizagem sem compreensão (Alexiou e Zamenopoulos, 2007).

A noção de aprendizagem sem compreensão nos traz para a discussão o mecanismo da aporia, introduzida a nós por outro pesquisador que entrevistamos, o teórico alemão Peter Matussek. O termo de origem grega “aporia” diz respeito à dificuldade, ao impasse, paradoxo, momento de auto-contradição que impede que o sentido de um texto ou de uma proposição seja determinado.

De acordo com o professor português de Estudos Literários Carlos Ceia, a aporia foi um recurso utilizado na filosofia grega antiga para atestar contradições entre dois juízos. Alguns diálogos platônicos foram definidos como "aporéticos" por serem inconclusivos. Aristóteles definirá a aporia como uma “igualdade de conclusões contraditórias" (Tópicos, 6.145.16-20 apud Ceia, 2009). Os primeiros diálogos platônicos são freqüentemente chamados de a poréticos porque finalizam comaporias. Em um dado diálogo, Sócrates pergunta ao interlocutorsobrea natureza ou definição de um conceito, por exemplo "virtude" ou "coragem". Sócrates então, através de testes refutativos, apresenta ao interlocutor que suas respostas são insatisfatórias. Após uma série de tentativas frustradas, o interlocutor admite que está em uma aporia sobre determinado conceito, assumindo a ignorância sobre o assunto. No diálogo aporérico “Ménon" de Platão(84 a.C.), Sócrates descreve o efeito purgativo de se conduzir uma pessoa à aporia: ela mostra ao interlocutor sua pseudo-ciência sobre determinado assunto instigando-o gradualmente o desejo de investigar sobre ele. Assim, pela "purificação" da falsa sabedoria do interlocutor, o leitor é desafiado a filtrar o texto das suas dificuldades, deixando sempre abertas as portas da significação (Ceia, 2009).

O termo também é usado com freqüência pelos desconstrutivistas, tais como Jacques Derrida e Paul de Man, alguns dos participantes de sua colocação dentro da teoria literária pós-estruturalista. A aporia é identificada pela leitura desconstrutiva do texto, que busca mostrar que o sentido nele atribuído atingirá invariavelmente o nível da indeterminação ou da indecidibilidade. Uma aporia cria uma tensão lógico-retórica que impede que o sentido de um texto se possa fixar.

Para Peter Matussek, a aporia é uma das chaves para a construção de Espaços de Conhecimento, "o conhecimento nasce nas pessoas a partir do sentimento de 
saber nada sobre nada". Além disso, o enigma colocado pela aporia, considerando a parte seus "efeitos mágicos" é um importante elemento das relações sociais (Huizinga, 2000, p. 125). Ao comentar as relações sociais nos jogos aporéticos, Huizinga recorda a importância da igualdade entre os sujeitos envolvidos:

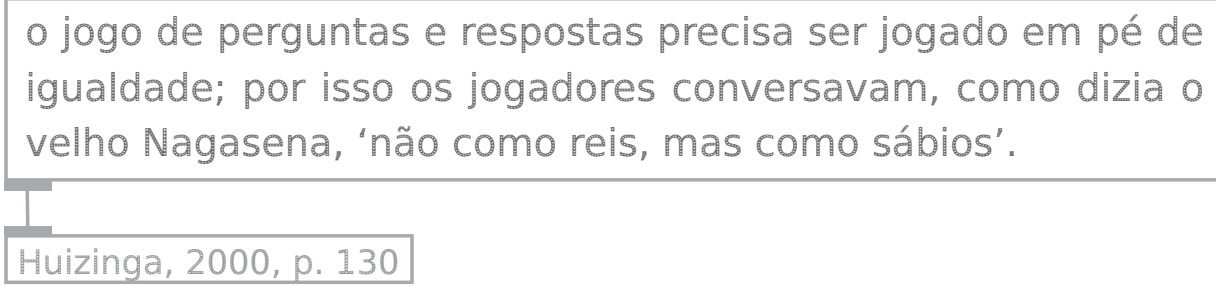

Mesmo que intuitivamente, em alguns processos de criação de instalações interativas de Arte Eletrônica, preza-se pela criação de propostas em que a experiência da interação proporcione ao interator a sensação aporética de que algo contraditoriamente foi inquietado dentro de si, de que alguma coisa foi perturbada em seu sistema psíquico. Essa sensação, por mais que as palavras tenham dificuldade de definir, é um dos mais importantes papéis desempenhados pela arte enquanto sistema social (Luhmann, 2007).

A exemplificação do uso da aporia na prática da Arte Eletrônica se dificulta por depender estritamente da percepção do sujeito, e talvez, seja como a noção de "obra aberta"de Eco, algo inatingível, mas que deve ser o fio condutor durante os processos criativos. Muitos artistas se arriscaram a perguntar diretamente a Eco se suas respectivas obras se constituíam enquanto "obras abertas". Eco sempre reafirma a inatingibilidade deste conceito.

\subsubsection{Informação, subjetividade e espaço}

A ubiqüidade com que a ideia de "informação" se apresenta em nosso cotidiano é fruto das transformações paradigmáticas que estamos enfrentando desde sempre na história das civilizações.

Com a emergência da cultura digital e suas implicações no campo da linguagem (Cabral Filho, 2005), a concepção do senso comum para a "informação" está profundamente enraizada em nossa cultura, sendo comum e erroneamente associada a expressões do conhecimento. Esta associação hoje em dia é tão familiar que muitas pessoas encaram a "informação" como estando em operações performadas em expressões, igualando-a a processos de conhecimento (Bijl, 1995, p.8). Como resposta a esta confusão, e fazendo trocadilho entre os termos "information" e "in formation", o arquiteto holandês Aart Bijl, afirma que "informação" é algo que somente adquire sentid o e relevância quando internalizada pelos sujeitos. 


A formalidade que aparece nas interações não contém
conhecimento, nem contem as outras coisas sobre as quais
nosso conhecimento se trata. Coisas formais, expressões, não
tem que conter, transportar ou representar qualquer coisa
para que sejam eficazes ao chegar dentro de nós mesmos.
Nosso conhecimento está no compromisso permanente de
pessoas.
Bijl, 1995, p. 18, tradução nossa63
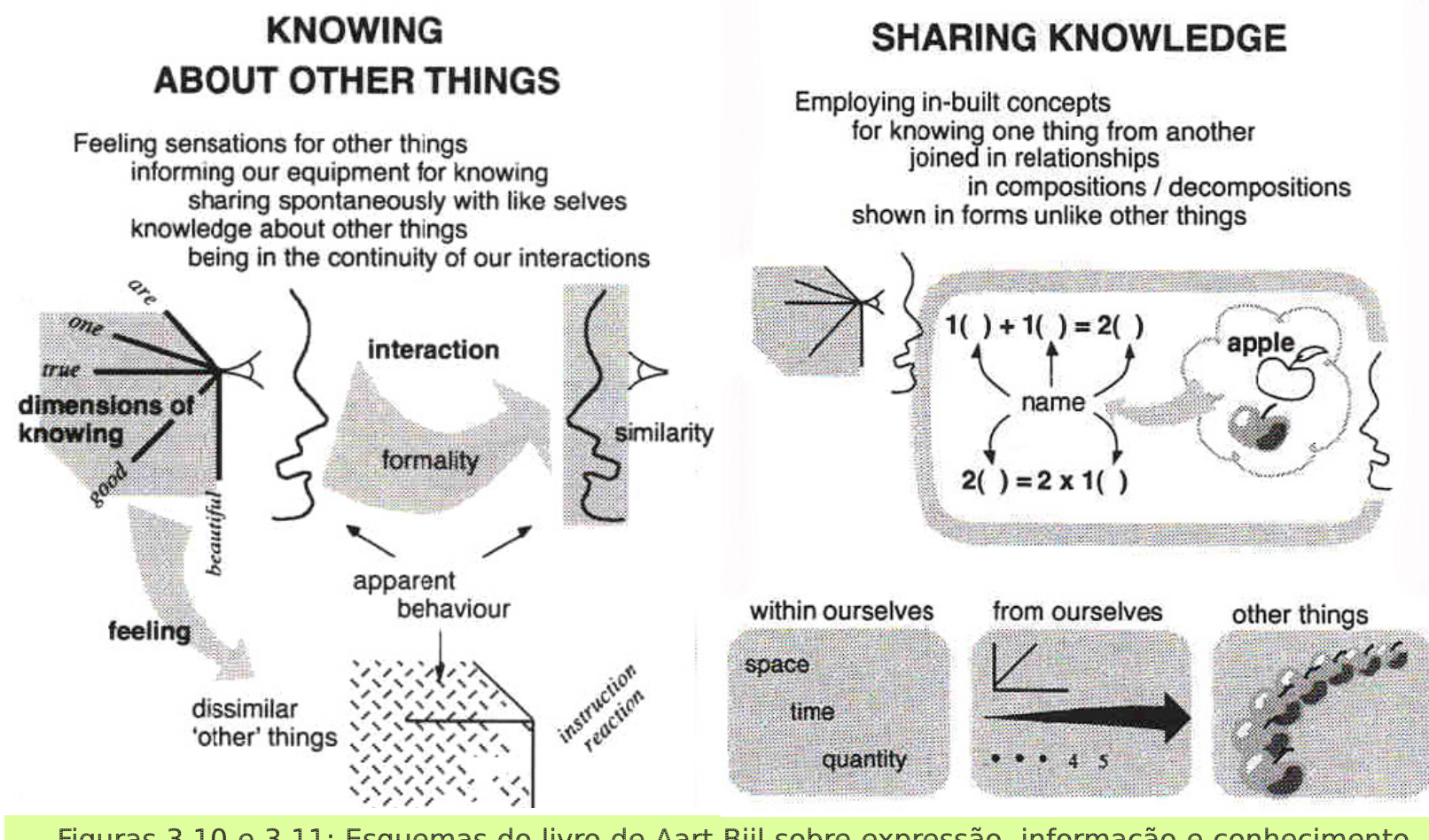

Figuras 3.10 e 3.11: Esquemas do livro de Aart Bijl sobre expressão, informação e conhecimento. Fonte: Bijl (1995, p. 12-3).

Nessa abordagem, o foco da atenção passa das expressões em si para as relações que se tecem entre os sujeitos, em seus processos de comunicação.

Cabe também rememorar diferentes correntes teóricas, a citar o pensamento de Pierre Teilhard de Chardin. No prólogo de sua obra "O Fenômeno Humano" (1965), o autor questiona que "se conhecer é verdadeiramente tão vital e beatificante, porque dirigir, insisto, a nossa atenção de preferência para o Homem?" (Chardin, 1965, p. 5). Em oposição, Niklas Luhmann, propõe uma teoria social abolindo o Homem como centro da discussão, sendo este o aspecto mais ousado e polêmico de sua teoria. Suas declarações compreendem:

\footnotetext{
63 Trecho original: "The formality which appears in interactions does not contain knowledge, nor does it contain the other things our knowledge is about. Formal things, expressions, do not have to contain, carry, or represent anyting for them to be effective in reaching into ourselves. Our knowledge is in the continuing engagement of people" (Bijl, 1995, p. 18).
} 
(1) A sociedade não se constitui de pessoas. Pessoas pertencem ao ambiente da sociedade. (2) A sociedade é um sistema autopoiético constituído por comunicações e nada mais. (3) A sociedade só pode ser adequadamente compreendida como a sociedade mundial.

Bechmann; Stehr, 1993 apud Luhmann, 1993, p. XV, tradução nossa64

O banimento do Homem que propõe a sociologia luhmanniana completa a descentralização da cosmologia humanista, mas considerá-la como um complexo de comunicações nos parece reforçar nossa responsabilidade sobre as atuações e sobre os processos de comunicação com os quais nos envolvemos

Para Flusser, que considera o "eu" (sistema psíquico para Luhmann) como um nó de informações armazenadas em cérebro humano que recebe e emite informações até se desfazer, considera que "o interessante na comunicação humana é o fato de os fios que religam os vários "eus" transmitirem precisamente esses acasos pouco prováveis, esses momentos de criatividade" (Flusser, 2008, p.117).

A perspectiva de Bijl sobre a interdependência humana no processo de construção do conhecimento reitera nossa responsabilidade na atividade de partilhá-lo, mesmo diante de um momento histórico em que o acesso a informação cada vez mais se automatiza e se agrega ao funcionamento de "aparelhos".

Na mesma direção, Flusser argumenta que, o homem como criador de aparelhos que contém programas que se opõem à tendência universal rumo à entropia, é um "ente que, desde que estendeu sua mão contra o mundo, procura preservar as informações herdadas e adquiridas, e ainda criar informações novas. Esta é a sua resposta à 'morte térmica', ou mais exatamente à morte" (Flusser, 2008, p. 26). Dessa forma, nossa preocupação em discutir sobre a construção de Espaços de Conhecimento se fundamenta no fato de acreditarmos em nossa habilidade em saber o que estamos fazendo para nós mesmos, enquanto seres inteligentes, e na escolha de um futuro no qual ainda continuemos a existir (Bijl, 1995, p. 09).

Siegfried Zielinski afirmou sobre a habilidade humana em construir e partilhar conhecimento:

\footnotetext{
64 Do original em inglês: "(1)Society does not consist of people. Persons belong to the environment of society. (2)Society is an autopoietic system consisting of communication and nothing else. (3)Society can only be adequately understood as world society" (Bechmann; Stehr, 1993 apud Luhmann, 1993, p. XV).
} 
a segunda característica que influencia o desenvolvimento da civilização é a habilidade culturalmente adquirida de coletar e armazenar conhecimento, bem como experimentar e transmiti-los a outros. Esta habilidade pode também conduzir a períodos em que desenvolvimentos qualitativos são extremamente concentrados: estes possivelmente não poderiam ser alcançados via mecanismos de evolução biológica.

Zielinski, 2006, p.06-07, tradução nossa65

É comum que se tenda, no que diz respeito às aparelhagens de comunicação e de pensamento, a negligenciar a dimensão de interioridade, de subjetividade coletiva, de ética e de sensibilidade, e que envolvem as decisões aparentemente mais técnicas (Lévy, 1998, p. 106). Não se pode ignorar que "as pessoas, as imagens, as palavras e os conceitos são mais ou menos estruturantes de acordo com a intensidade afetiva que se liga a eles" (Lévy, 1998, p. 125).

Em concordância com o pensamento destes vários autores, localizamos os processos criativos e colaborativos da Media Art como uma prática em que se baseia o laço social na relação com o saber e que, ao mesmo tempo, atravessa o mais íntimo das subjetividades (Lévy, 1998).

Provavelmente levaremos ainda algum tempo para nos adaptar e começarmos a agir com maturidade diante das novas configurações sociais proporcionadas pela cultura digital. Nosso desafio parece estar justamente em descobrir como conseguir colocar nossa discussão em prática, nos atentando criticamente à maneira como nossas ações ganham expressão no espaço.

Nos interstícios entre espaço e subjetividade, Wolfgang Strauss e Monika Fleischmann, que trabalham bastante sobre o conceito de Espaços de Conhecimento, afirmam que ele também pode ser o "espaço em sua cabeça. É também o espaço da memória". Strauss ainda sintetiza: "Pensar é como uma casa" (Strauss, 2008, tradução nossa66).

Umberto Eco afirmou sobre nossa natureza:

\footnotetext{
65 Do original em inglês: "The second trait that influences the development of civilization is the culturally aqcquired ability to collect and store knowledge and experience and to pass these to others. This ability can also lead to periods where qualitative developments are extremely concentrated: these could not possibly be achieved via the mechanisms of biological evolution" (Zielilnski, 2006, p.6-7).

66 Excerto original extraído de entrevista realizada em 25/Abril/2008 em Osnabrück, Alemanha: "the space in your head. It is also the memory space. Thinking is like a house" (Fleischmann, Strauss, 2008).
} 
Ninguém vive no presente imediato; ligamos coisas e fatos graças à função adesiva da memória pessoal e coletiva (história e mito). Confiamos num relato anterior quando, ao dizer "eu", não questionamos que somos a continuação natural de um indivíduo que (de acordo com nossos pais ou com o registro civil) nasceu naquela determinada hora, naquele determinado dia, naquele determinado ano e naquele determinado local. Vivendo com duas memórias (...) muitas vezes tendemos a confundi-las, como se tivéssemos testemunhado o nascimento de nossa mãe (e também o de Júlio César) da mesma forma como "testemunhamos" as cenas de nossas experiências passadas.

Eco, 1994, p.137

Trafegar entre essas duas instâncias de memória é também uma forma de imersão e distanciamento. Podemos falar que em nosso processo de aprendizado, a todo instante nos remetemos ao que é nosso e ao que é do outro, de nossas referências, nos víamos distintos de nossa caixa-preta. Tentamos a todo instante nos observar interagindo com ela. De dentro pra fora. De fora pra dentro. Do micro ao macro. Do macro ao micro. Abertos aos acidentes mas sempre atentos às situações à que nos lançávamos, nos moldes de como definiu Peter Matussek durante entrevista:

Por situações quero dizer espaços experimentados por sujeitos... nós não vivemos em espaços, não vivemos em ambiente, vivemos em situações. (...) e situações são também feitas por sujeitos, bem como pela experiência subjetiva de nossos sentidos. (...) Ambiente é uma coisa que me dá objetos e processos para detectar e perceber. Situações também são feitas por atmosferas. Atmosfera é uma noção que dificilmente temos em termos objetivos. Atmosferas são objetos performativos. Atmosferas registramos quando entramos numa sala, por exemplo. (...) As mídias também são nossos sentidos. (...) Criamos espaços, criamos objetos, criamos experiências sensoriais, orientadas por atividades mentais construtivas.

Matussek, 2008, tradução nossa67

${ }^{67}$ Excerto original transcrito de entrevista realizada: "Situations I mean spaces that are experienced by subjects... we do not live in spaces, we do not live even in environments, we live in situations. (...) Environment is something that gives me objects and process to detect and to perceive. Situations are also made by atmospheres. Atmospheres is a notion that we can hardly have in objective terms.Atmospheres are performative objects.Atmospheres we register when we enter in a room, for example... (...) Media are also our senses. (...) we create spaces, we create objects, we creat sense experiences, oriented by mental constructive activities" (Matussek, 2008). 
A colocação de Matussek nos lança para o universo complexo das intrínsecas e recursivas relações entre nós e nossas caixas-pretas e de certa forma reitera a necessidade de superação das perspectivas dicotômicas do objetivo e do subjetivo, do dentro e do fora, ou mesmo do acidente e do programa. No item a seguir procuramos delinear alguns caminhos possíveis de como trazer para o campo da arquitetura esta nossa abordagem.

\subsection{Considerações}

Neste capítulo esperamos ter amadurecido a auto-crítica de nosso processo, através da explicitação dos mecanismos de nossa pesquisa.

Vislumbrando a experiência criativa coletiva que se tece entre acidente e controle enquanto possibilidade de construção de Espaços de Conhecimento, tentaremos a seguir levar para o campo da Arquitetura o que apreendemos do processo de produção da Media Art. Com isso esperamos contribuir com referências para se pensar maneiras diferenciadas de se construir espacialidades na contemporaneidade. 


\section{CONSIDERAÇÕES FINAIS}

Como na história da cultura a Arte sempre se apresentou como um campo onde são possíveis as mais avançadas e livres experimentações (Cabral Filho, 2005), no período de transição entre a cultura analógica e a cultura digital, no mínimo vale a pena a Arquitetura olhar para o que vem sendo desenvolvido no campo da Arte Programmata.

Longe de ser uma transição simplesmente tecnológica, a transição entre o analógico e o digital, ou melhor, a interlocução entre os dois universos, inaugura uma maneira diferenciada de pensar e projetar, baseada simultaneamente em nossa era da indeterminação e em nossa habilidade de coordenar os processos criativos e executivos.

Assim como na produção de Media Art, a produção arquitetônica atravessa processos de projeto e de execução, sob a coordenação de sujeitos de diferentes áreas de conhecimento. Nos dias de hoje, quando o modelo mítico do gênio criador solitário está praticamente extinto, notamos que projetos de relevância nas áreas criativas requerem equipes de designers que coordenem as diversas especialidades envolvidas no processo para se chegar a soluções eficazes de design de interfaces e espacialidades. Como a parte executiva de um projeto se torna uma espécie de campo de soluções de problemas criados pelos próprios sujeitos em suas propostas, pensar como se desenrola a coordenação da atividade pode trazer um amadurecimento dos profissionais e da equipe como um todo.

A coordenação dos processos e das decisões complexas que emergem das atividades criativas envolvem diversos agentes e componentes de conhecimento interligados de diferentes maneiras. O desafio de se balancear as ações entre o programa a ser executado e os acidentes que interpelam os caminhos dos realizadores (artistas, designers, arquitetos, etc.) exige a coordenação de metas, recursos, requisitos e conhecimento de outros agentes de igual importância envolvidos no processo, como os clientes, patrocinadores e público em geral (Alexiou; Zamenopoulos, 2007, p.586).

Dentre as etapas para o desafio de gerenciamento de interdependências presente em qualquer área do design, Alexiou e Zamenopoulos colocam, entre outras coisas a necessidade de estabelecer relações de tradução entre as diferentes representações; definir papéis e estruturas nas organizações; sincronizar a troca de informação; e ordenar as atividades executivas (Alexiou; Zamenopoulos, 2007, p.587). 
Em contraposição aos processos tradicionais de projeto e execução arquitetônica, na era da cultura digital e da potência da "inteligência coletiva", cabe investigar processos diferenciados, em que as tecnologias de informação e comunicação possam influenciar no desenvolvimento do projeto e do produto final. A tecnologia digital, em sua considerável abertura e indeterminação de seu cerne programático (Cabral Filho, 2005), inspira arquitetos jovens como Usman Haque, Chris Leung, Cesar Harada, entre outros. Estes experimentam processos que não entendem as ferramentas $\mathrm{CAD}$ apenas como mero instrumento de desenho, reproduzindo com os computadores o que se fazia há séculos com o papele o nanquim; mas adotam novas metodologias quetrafegam pela criatividade disciplinada e aberta ao acaso menos provável descrita por Flusser, e culminam na criação de novas tipologias de espacialidades.

Para ilustrar o que queremos dizer, usaremos o exemplo do "Pachube" 68 , de Usman Haque. "Pachube" é uma plataforma disponível na internet que permite aos usuários armazenar, compartilhar, descobrir e interconectar espacialidades ao redor do mundo em tempo real. Através da disponibilização colaborativa de informações, sensores (inputs), objetos, equipamentos, ambientes e edifícios receptores de dados (outputs) existentes ao redor do mundo, o objetivo da plataforma é facilitar a interação entre ambientes remotos, tanto físicos como virtuais (Haque, 2009).

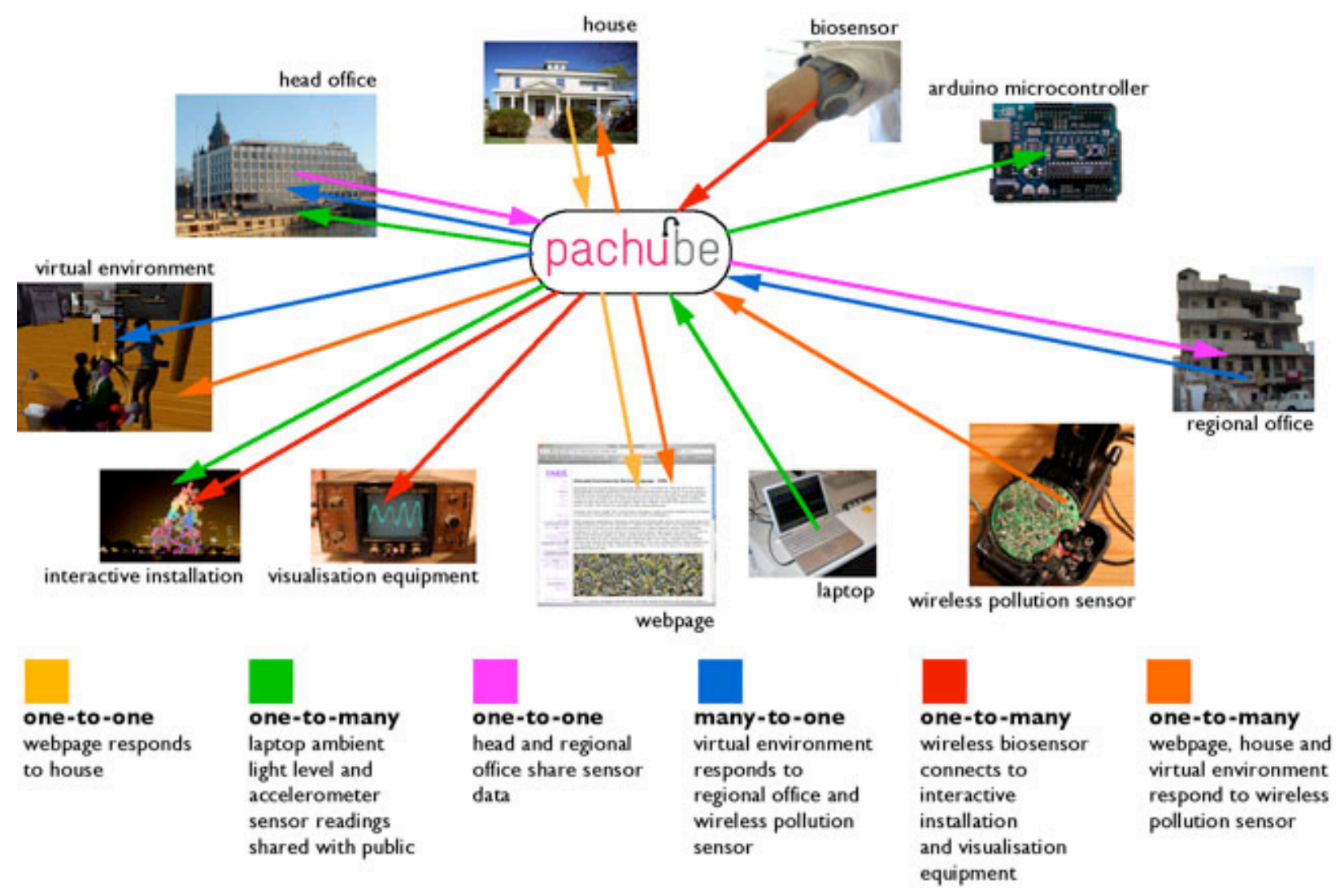

Figura 4: Diagrama da plataforma Pachube. Fonte: Haque (2009, website).

68 Site oficial disponível em http://www.pachube.com. Acessado em 08/Out/2009. 
Segundo a arquiteta e pesquisadora ciberneticista Anja Pratschke, o projeto "Pachube" de Usman Haque "rompe com uma longa história de produção de instalações e sistemas que exploraram aspectos festivos e de interatividade" e inclusive contribui na "revisão do que é arquitetura na era digital" (Pratschke, 2009) uma vez que as pessoas têm usado a plataforma para criar "aplicativos de monitoramento remoto, integrar sistemas de gestão de edifícios, desenvolver sistemas de geo-rastreamento, criar "mashups" e objetos de rede, e toda uma série de outras coisas" (Haque, 2009, website). Pratschke coloca ainda que

inspirado pelo projeto Cybersyn, desenvolvido por Stafford Beer (ciberneticista inglês, da área de Administração) para o governo Salvador Allende, no Chile, nos anos 1970, Pachube parte da ideia de um planeta reconfigurável. Plugado em um sistema generalizado, ele cria a conexão arquitetônica através da diversidade de dados, e, assim, propõe um novo formato de arquitetura - que o autor chama de arquitetura estendida.

Pratschke, 2009

Um outro aspecto inovador da plataforma está no intuito de auxiliar inclusive na capacitação de pessoas para as possibilidades ampliadas de diálogos e de convergência da cultura digital, ao buscar tornar simples a criação de aplicações, produtos e serviços que interconectam os mundos físico e virtual.

Ainda, no processo de experimentação dos usuários, que podem realizar conexões ponto-a-ponto ou multiponto, ao programarem a captura dos dados de entrada (a partir de sensores remotos) e a disponibilização de dados de saída (para atuadores remotos), estão abertas as possibilidades para conexões espontâneas e/ou planejadas. O exemplo do Pachube é significativo em nosso trabalho por ser uma iniciativa concreta no estímulo à criatividade na era da cultura digital, proporcionando a possibilidade às pessoas de atuarem criativamente entre o acaso e a programação.

Para o criador da plataforma, "através do uso extensivo de metadados, Pachube agrega valor à interconexão física: não é apenas sobre fluxos de dados, mas sobre os ambientes que compõem os fluxos de dados" (Haque, 2009, website). Entendemos que esse tipo de uso híbrido do espaço constitui-se como uma forma de ampliar a capacidade humana de modificar e administrar os espaços em que se vive. Estamos a todo o tempo conectando-os, separandoos, articulando-os, explorando-os e experimentando-os, com a inserção de 
elementos e deslocamento de suas intensidades, ou mesmo abandonando-os para uma nova experiência em outro espaço (Lévy, 1998, p. 126).

Em nossa discussão nos perguntamos se o "Pachube" de Usman Haque não seria a possibilidade de concretização da "Cybernetic Art Matrix" proposta por Ascott nos anos 1960, ou uma extensão favorável ao crescimento do "formigueiro criativo" de Flusser?

Na sinergia entre o acaso e o programa da cultura eletrônico-digital, o "formigueiro criativo" de Flusser, além de simbolizar a potência da colaboração entre grupos, aponta para nossa libertação da necessidade de mudar o mundo, que se transforma automaticamente. Para Flusser, na cultura eletrônico-digital somos potencialmente livres, via imagens técnicas, para atribuir significado ao mundo.

Dizemos potencialmente, porque apesar de nossas possibilidades criativas ampliadas, no movimento entrópico da sociedade, assistimos a uma produção desvairada das imagens técnicas, que nos proporcionam uma sensação espectral de esvaziamento. Sobre o vazio da maré de imagens técnicas que nos assola cotidianamente, ele afirma: "não é o medo do futuro que nos paralisa, mas o medo de não haver mais futuro. Como não é o medo da morte que nos paralisa, mas a visão do vazio 'depois da nossa morte'"(Flusser, 2008, p. 85). E de repente nos vemos de volta à estaca primordial da existência humana e da existência das imagens: o medo da morte (Debray, 1993).

$\mathrm{Na}$ busca por ir contra este esvaziamento é que nos comprometemos com o nosso objeto de análise e, à luz dos conceitos da Cibernética de Segunda Ordem, discutimos as principais características da produção de Arte Eletrônica contemporânea tanto em seu âmbito estrutural como no das relações entre as pessoas que se envolvem neste cenário.

Procuramos demonstrar como na sua qualidade de arte-processo, a Media art está permeada pelo jogo entre acidente e controle, assunto que se constituiu como o fio condutor de nosso argumento e que foi trabalhado em diferentes aspectos a cada capítulo.

No capítulo um, ao nos aprofundarmos sobre o uso de algoritmos no âmbito da Arte e aos trazermos às concepções de Vilém Flusser sobre "automatizar" e "programar", percebemos a maneira pela qual as relações entre acidente e controle estruturam o fazer artístico, sem no entanto, fechar as portas para a indeterminação.

No capítulo dois, quanto trazemos a concepção de acidente e controle para a noção da criatividade na era da cultura digital, adicionamos uma nova camada para o entendimento do assunto, reiterando a responsabilidade dos agentes criadores na tarefa de correr riscos para trazer ao mundo novos paradigmas de comunicação que enriqueçam e aperfeiçoem as relações humanas e as estruturas sociais.

No terceiro capítulo, de caráter mais sintética, quando nos propomos 
a realizar uma crítica ao nosso próprio processo de pesquisa e análise, nos percebemos outra vez dentro do processo infinito de construção de um Espaço de Conhecimento.

Pela reverberação deste nosso pensamento e através da discussão das concepções discutidas nos capítulos anteriores, tocamos na possibilidade dea a incorporação das noções de acidente e controle no fazer arquitetônico. Abrimos a possibilidade de se revisar a maneira que construímos e experimentamos as espacialidades e o nosso entorno em na atual situação cultural.

O argumento que desenvolvemos, em suas diferentes camadas, atesta a complexidade do assunto e, sobretudo nos permite olhar para a noção de controle de um modo diferenciado, sem o estigma da manipulação centralizadora e totalitária. Retomando Flusser, nossa perspectiva é aquela de que o poder em exercer a liberdade está muito mais pautado em dizer "não" do que "sim", e assim elegermos a opção anti-redundância (Flusser, 2008).

As nossas colocações, baseadas nas críticas de diferentes autores e na oportunidade de tocar o assunto empiricamente, ajudam a compreender com mais clareza a complexidade das mudanças de paradigmas que enfrentamos frente à cultura eletrônico-digital. Seja na Arte ou na Arquitetura, como resposta ao movimento da entropia, nossa criatividade disciplinada deve estar aberta ao acaso menos provável dentre todos os outros acasos.

Sobre nossa experiência prática no campo da Media Art, apesar de não termos atingid o a complexidade da autonomia e da recursividade da Cibernética de Segunda Ordem, fomos despertados para a consciência da importância do processo experimental, capaz de desencadear de uma certa "vontade de saber". E como o olhar sobre o processo, descobrimos que não se trata de abandonar o passado e virar a página da história; mas sim de encontrar a novidade e a diversidade através do diálogo com referências anteriores.

Além disso, a discussão aponta para uma situação em que, mesmo que estejamos utilizando ferramentas cada vez mais dinâmicas e complexas, nosso foco ainda deve se manter nas atividades humanas, descobrindo caminhos possíveis na redefinição das identidades e das estruturas sociais. Para isso, precisamos constantemente nos auto-avaliar e rever os próprios critérios de avaliação.

Flusser, que se apresentou como um entusiasta do potencial da produção coletiva das imagens sintéticas, e por extensão da Media Art, também se posicionou criticamente aos desdobramentos concretos das promessas da cultura eletrônico-digital. O autor nos lembra que os aparelhos são meros "autômatos infra-humanamente cretinos" (Flusser, 2008, p. 78) e que nada "querem", apenas rolam pela inércia da tendência entrópica, rumo à semelhança circular. A vontade inicial dos programas vai se diluindo, até evaporar totalmente. Diante de vários aparelhos com programas opostos coexistindo, podemos tomar partido de um lado e de outro, e corremos o risco de enfrentar, entre outras coincidências, aquela mais provável e mais entrópica: 
a de que "todos os aparelhos se unifiquem num único aparelho cósmico que obedeça a um único 'meta-programa'" (Flusser, 2008, p.79). Neste contexto, a utopia da proposição de Flusser seria evitar o totalitarismo de um único superaparelho. E para tal, ele nos sugere o engajamento que vise inverter o fluxo dos programas, através da emergência de um outro homem, "que participe de diálogo cósmico 'sobre' aparelhos" compondo uma "democracia" no sentido pós-histórico: uma "democracia programadora de aparelhos"(2008, p. 80).

Em relação ao "Espaço do saber", retomamos Pierre Lévy para colocar que este também se constitui como uma utopia, uma espécie de não-lugar:

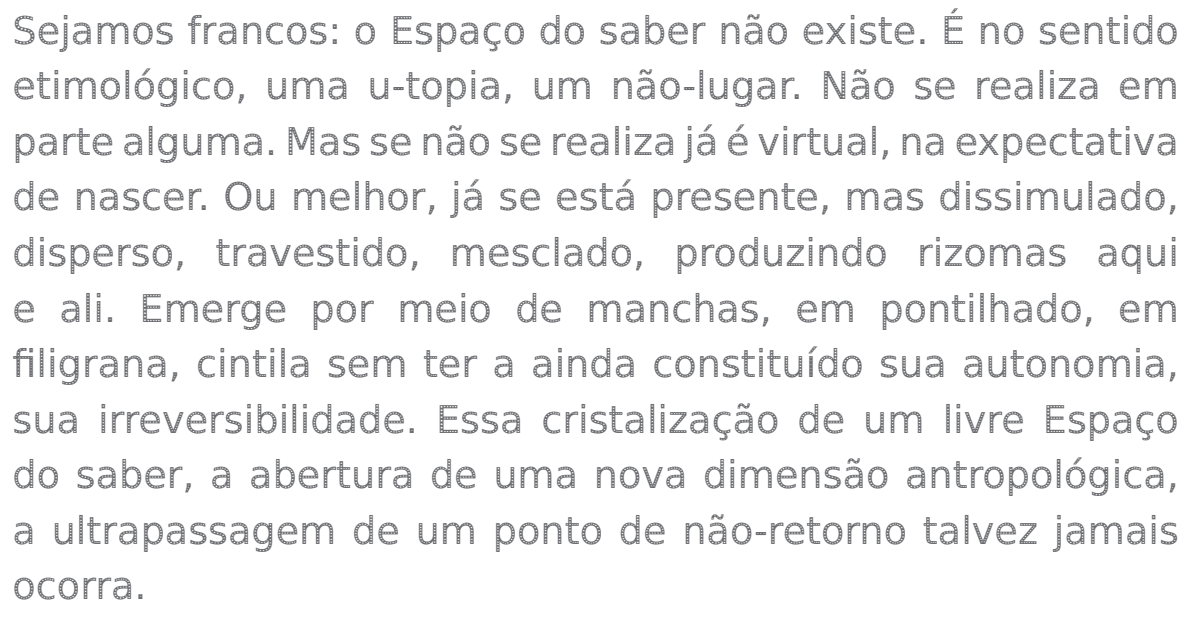
etimológico, uma u-topia, um não-lugar. Não se realiza em parte alguma. Mas se não se realiza já é virtual, na expectativa de nascer. Ou melhor, já se está presente, mas dissimulado, disperso, travestido, mesclado, produzindo rizomas aqui e ali. Emerge por meio de manchas, em pontilhado, em filigrana, cintila sem ter a ainda constituído sua autonomia, sua irreversibilidade. Essa cristalização de um livre Espaço do saber, a abertura de uma nova dimensão antropológica, a ultrapassagem de um ponto de não-retorno talvez jamais ocorra.

Lévy, 1998, p.120

Se por um lado o Espaço de Conhecimento é um não-lugar e não existe no sentido de que ainda não ganhou autonomia; por outro ele, enquanto entidade virtual, "sua qualidade de ser é tal que seu grito ecoa na eternidade: o Espaço do saber sempre existiu" (Lévy, 1998, p.121). Nessa perspectiva, também a condição de existência do Espaço de Conhecimento se constitui como um jogo aporético de paradoxos insolúveis.

Assumimos a natureza utópica de nossa proposição, mas caracterizamos a (re)construção do laço social como uma concepção de modo de vida que deve ser retomada no atual momento histórico, quando "grupos humanos implodem, cancerizam-se, perdem seus pontos de referência, e vêem suas identidades se degradar" (Lévy, 1998, p. 26). Nossos autores apontam para a urgente necessidade de se explorar vias diferenciadas de inserção social, uma vez que a produção de comunidades por pertencimento étnico, nacional ou religioso, conduz aos conhecidos impasses insolúveis. Relembremos Lévy defendendo que "basear o laço social na relação com o saber consiste em encorajar a extensão de uma civilidade desterritorializada, que coincide com a fonte contemporânea da força, ao mesmo tempo em que passa pelo mais íntimo das subjetividades" (Lévy, 1998, p. 26-27). Além disso, em perspectiva 
ampla, ele coloca que a inteligência coletiva é discutida por Lévy enquanto um "projeto global cujas dimensões éticas e estéticas são tão importantes quanto os aspectos tecnológicos ou organizacionais" (Lévy, 1998, p. 26).

Assumimos também que existe um forte caráter utópico em relação ao uso da Cibernética, como colocou Claus Pias ao questionar os limites de sua aplicação. No contexto da reformulação radical da maneira de se pensar a tecnologia, a Cibernética fez emergir uma nova ordem para as coisas, sonhando com vários modos de reconciliação, compondo uma espécie de "epistemologia experimental" (Pias, 2005, p.544). O experimento repousa na reordenação do conhecimento de uma forma que fenômenos psicológicos e sociológicos, políticos e econômicos, estéticos e biológicos possam ser observados como enraizados nos termos da comunicação e da recursividade.

No mais, sim, a caixa-preta é uma invenção, não podemos ver dentro porque não há dentro. Não podemos abrir porque ela não está lá. Nos cabe inventar uma série delas para experimentar o confronto entre o potencial transformativo e as práticas conservadoras que nos circundam. E a cada novo experimento, que saibamos eleger o acaso menos provável entre todos os outros acasos prováveis. A Media Art é um campo experimental por excelência e pode servir a este propósito. A Arquitetura também. Ou, por que não? 


\section{REFERÊNCIAS}

ALEXIOU, K.; ZAMENOPOULOS, T. (2007). Design as social process: a complex systems perspective. In: Science Direct/Elsevier, Futures 40, p.586-595.

ARGAN, G. C. (1995). História da arte como história da cidade. São Paulo: Martins Fontes.

ARRIGHI, M. (2008). Entrevista por Graziele Lautenschlaeger. Linz, 13maio.2008. Arquivo de audio, CD.

ARNS, I. (2008). Interaction, participation, networking art and telecommunication. Disponível em <http://www.medienkunstnetz.de/overview_of_media_art/ communication/> Acesso em 25abr.2008.

ART+COM (2009). <http://www.artcom.de>. Acesso em 27Jan2009.

ASCOTT, R. (2003). The construction of change. In WARDRIP-FRUIN, N., MONFORT, N., The new media reader. Cambridge: MIT Press. p. 127-132.

. (1968) Cybernetic Stance: my process and purpose. Pergamon Press: Leonardo, Vol. 1, p. 105-112.

- (2003) Telematic Embrace: Visionary Theories of Art, Technology, and Consciousness. Edward A. Shanken (Ed.), Berkeley:University of California Press.

. (1983). La plissure du text: a distributed autorship project for ARTEX. <http:// alien.mur.at/rax/ARTEX/PLISSURE/plissure.html>. Acesso 16Jun2009.

ALMEIDA, M. J. (1999). Cinema: Arte da Memória. Campinas: Editores associados.

ARNHEIM, R. (1997). Arte e percepção visual: uma psicologia da visão criadora. São Paulo: Pioneira/Editora da Universidade de São Paulo.

. (2007). The coming and going of images. In GRAU, O. (ed). MediaArtHistories. Cambridge, The MIT Press.

AUGÉ, M. (2004). Não-lugares. Campinas, SP: Ed. Papirus.

BACHELARD, G.(1993). A Poética do espaço. São Paulo: Martins Fontes.

. (1988). A Poética do Devaneio. São Paulo: Martins Fontes.

BAUDRILLARD, J. (1991). Simulacros e simulação. Lisboa: Relógio d'água.

BAMBOZZI, L. (2000). Media art, interfaces e interatividade. Belo Horizonte: GeraisUFMG. pp.37-39.

BENAYOUN, M. (2008) Entrevista por Graziele Lautenschlaeger. Paris, França, 10Jul.2008. Arquivo de áudio, CD.

. (2009). <http://www.benayoun.com>. Acesso em 30jun2008. 
BENJAMIN, W. (1993). A obra de arte na era de sua reprodutibilidade técnica. In Magia e técnica, arte e política (obras escolhidas). São Paulo: Brasiliense, pp. 165-196.

BERNARD, Y. (2008). Entrevista por Graziele Lautenschlaeger. Bruxelas, Bélgica, 23.jun.2008. Arquivo de áudio, cd.

BERNARD, Y; QUARANTA, D. (2008). Holy Fire: art of the digital age. Brescia: fpeditions. Catálogo.

BUJL, A. (1995). Ourselves and computers: difference in minds and machines. London: Macmillan Press, 1995.

BISHOP, J.M.; NASUTO, J.S. (2005) Second-order cybernetics and enactive perception. In Kybernetes. Vol.34, no 9/10, p.1309-1320.

BLANCHOT, M. (1993). The Infinite Conversation. Minneapolis and London: University of Minnesota Press.

BROECKMANN, A. (2007). Image, process, performance, machine: aspects of an aesthetics of the machinic. In GRAU, O. (ed). MediaArtHistories. Cambridge, The MIT Press.

BULLIVANT, L. (2007) Playing with art. In: Archithectural design. Volume 77, Issue 4, July/August, p. 32-43.

CABRAL FILHO, J. S. (2005) Digital art: a field of inquiry for contemporary architecture. In: IJAC - The International Journal of Architectural Computing. Outubro, p.1-19.

CAPRA, F. A teia da vida: uma nova compreensão científica dos sistemas vivos. São Paulo: Editora Cultrix, 1996.

CHARNEY, L.; SCHWARTZ, V. R. (Orgs.) (2001). O cinema e a invenção da vida moderna. São Paulo: Cosac \& Naify.

COHEN, R. (2002). Performance como linguagem. São Paulo: Perspectiva.

CORTÁZAR, J. (2004). Histórias de cronópios e de famas. Rio de Janeiro: Civilização Brasileira.

COUCHOT, E.(1996). Da representação à simulação: evolução das técnicas e das artes da figuração. In Imagem-máquina: A Era das Tecnologias do Virtual. Rio de Janeiro: Editora 34.

DARTEL, M. van. (2008). Entrevista por Graziele Lautenschlaeger. Por email 30jul2008. Arquivo de texto.

DEBRAY, R. (1993). Vida e morte da imagem: uma história do olhar no ocidente. Petrópolis/RJ: Vozes.

DICK, B. (2005) Grounded theory: a thumbnail sketch. Disponível em <http://www. scu.edu.au/schools/gcm/ar/arp/grounded.html>. Acesso em 05Jul2009.

ECO, U. (1994). Seis passeios pelos bosques da ficção. São Paulo: Cia. das Letras.

E-FLUX (2008). <http://www.e-flux.com/journal/view/37>, Acesso em 02Fev2009.

EUROPEAN GRADUATE SCHOOL (2000).<http://www.egs.edu/faculty/zielinski.html>. 
Acesso em 25Mar2009.

FELL, A.F.A.; XIMENES, A.F.; RODRIGUES FILHO, J. (2004). Pesquisa qualitativa em sistemas de informação (S.I.) no Brasil: uma análise da produção acadêmica. In: SIMPÓSIO DE ENGENHARIA DE PRODUÇÃO, 11, 2004, Bauru. Anais... Bauru: FEB/ Unesp.

FERRARA, L. D. (2002). Imagem virtual, espaco global, tempo continuo. In Design em espaços. Coleção Textos Design. São Paulo: Edições Posari Ltda.

FEUILLIE, N. (2002). Fluxus Dixit, une Anthologie vol.1, Dijon: Lê presses du réel. pp. 50 e 51.

FLEISCHMANN, M.; STRAUSS, W. (2008). Entrevista por Graziele Lautenschlaeger. Osnabrück, Alemanha. 25abr.2008. Arquivo de áudio, CD.

. (2009). <http://fleischmann-strauss.de/index.html>. Acesso em 15Jun2009.

FLUXUS PORTAL disponível em <http://www.fluxus.org > acessado em 07 de setembro de 2006.

FLUSSER, V. (1988). Arte viva. In: Ficções filosóficas. São Paulo: Editora da Universidade de São Paulo. p.83-88.

- (1998). Criação científica e artística. In: Ficções filosóficas. São Paulo: Editora da Universidade de São Paulo. p. 171-176.

. (2006). Do Inobjeto. In Revista Ars. Ano 4, n.8, São Paulo, Departamento de

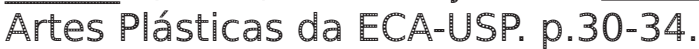

Annablume.

- (2008) Universo das imagens técnicas: elogio da superficialidade. São Paulo,

FOUCAULT, M. (1986). Espaços outros. Conferência proferida no Cercle d'Études Architecturales, em 14 de março de 1967. Tradução: Pedro Moura. Diacritics; v.16, n.1, 1986.

Brasileiro.

- (1972). A arqueologia do saber. Petrópolis: Vozes. Lisboa: Centro do Livro

FRANÇOIS, C. (1999). Systemics and Cybernetics in a Historical Perspective. In Systems Research and Behavioral Science. Syst. Res. 36, p.203-219.

GIANNETTI, C. (2006). Estética digital: sintopia da arte, a ciência e a tecnologia. Belo Horizonte: C/Arte.

GLANVILLE, R. (2001) Second order cybernetics (6.46.3.3), manuscrito não publicado, distribuíd o como leitura básica para conferência American Society for Cybernetics 2001, 'Treasures of Second-Order Cybernetics' Workshop. Vancouver, 2001. Disponível como "C2 revising text 2.3" em: <http://homepage.mac.com/WebObjects/FileSharing. woa/wa/default? user=ranulph\&fpath=papers\%20etc:cybernetics\&templatefn=Files haring1.html>, acessado em 29/Outubro/2008.

- (2007). Try again. Fail again. Fail better: the cybernetics in design and the design in cybernetics. In: Kybernetes. Vol.36, n 9/10. p. 1173-1206.

- (2009). Black Boxes. In Cybernetics \& Human Knowing: a journal of second-

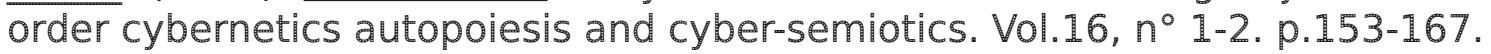


GLYNN, R. (2008). Conversational Enviroments Revisited. Disponível em: <http:// www.interactivearchitecture.org/pdfdocs/Conversational-Environments-RevistedCybernetic-Conference-Paper-2008.pdf> acessado em 06.agosto.2009

GODOI, C.K.; BANDEIRA-DE-MELO, R.; SILVA, A. B. (Org.) (2006). Pesquisa qualitativa em estudos organizacionais: paradigmas, estratégias e métodos. São Paulo: Saraiva.

GRAU, O. (2007). Arte virtual: da ilusão à imersão. São Paulo: Editora Unesp: Editora SENAC São Paulo.

GSÖLLPOINTNER, K. (2008). Architectur und elektronische Medien/Architecture and electronics. In Intelligente Ambiente/Intelligent Enviroment. p.28-37.

. (2008). Cybernetics of Art: aesthetics of language. Palestra no Interface Culture Department. Linz, Áustria. 27maio.2008. Arquivo de audio.

HALL, S. (2002). A identidade cultural na pós-modernidade. Tradução: Tomaz Tadeu da Silva e Guacira Lopes Louro. Rio de Janeiro: DP\&A..

HALL, D.; FIFER, S.J. (1990) Illuminating Video - An Essential Guide to Video Art, New York, 1990.

HAQUE, U. (2009). Pachube. <http://www.pachube.com>. Acesso em 08Out2009.

HARVEY, D. (1992). A condição pós-moderna: uma pesquisa sobre as origens da mudança cultural. Tradução: Adail Ubirajara Sobral e Maria Stela Gonçalves. São Paulo: Edições Loyola.

HUHTAMO, E. (1995). Ressurrecting the technological past: an introduction to the archeology of media art. Intercommunication $n^{\circ} 14$.

HURST, M. (2009). Data mining: Maping the Blogsphere. <http://datamining.typepad. com/gallery/blog-map-gallery.html> Acesso em 08Nov2009.

. (2009).Discover: Science Technologyand The Future. <http://discovermagazine.

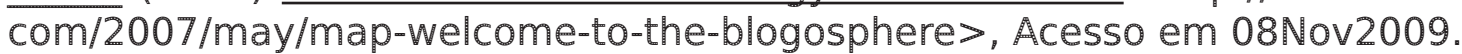

JOHNSON, Steven. (2001). Cultura da interface. Rio de Janeiro, RJ: Jorge Zahar Editor.

KLEIN, N. M. (2004). The Vatican to Vegas: a History of special effects. New York: The New Press.

KUZMANOVIK, K.; MAES, A.; BERNARD, Y.(Ed.) (2006). X-med-a. Printed by Roels V, Antwerp, Belgium. Brussels.

KWASTEK, K. (2008). Entrevista por Graziele Lautenschlaeger. Linz, Áustria. 10set.2008. Arquivo de áudio, CD.

LAURENTIZ, S. (2006). Uma aproximação da cibernética pela poesia digital. In Revista Ars. Ano 4, n.8, São Paulo, Departamento de Artes Plásticas da ECA-USP. p.115-127.

LÉVY, P. (1998). A inteligência coletiva: por uma antropologia do ciberespaço. São Paulo: Loyola. 
informática. Rio de Janeiro: Ed. 34.

. (1999). Cibercultura. Tradução: Carlos Irineu da Costa. São Paulo: Ed.34.

. (1996). O que é o virtual? Tradução: Paulo Neves. Rio de Janeiro: Ed.34.

LUHMANN, N. (2000). Art as a social system. Palo Alto: Stanford University Press.

. (1993). Risk: a sociological theory. New York: A de Gruyter.

MANOVICH, L. (2003). New media from Borges to HTML. in WARDRIP-FRUIN, N., MONFORT, N. (ed.), The new media reader. Cambridge: MIT Press. p. 13-25.

MARESCH, P. (2008). Entrevista por Graziele Lautenschlaeger. Linz, Áustria. 03jun.2008. Arquivo de áudio, CD.

MARTÍ, S. (2009). Arte-tecnologia tem auge financeiro. Folha de S. Paulo, São Paulo, 28jul2009, llustrada, Caderno E, p. E8.

MARTINS, T. (2008). Entrevista por Graziele Lautenschlaeger. Linz, Áustria. 22 maio.2008. Arquivo de áudio, CD.

MARTINS, T.; CORREIA, N. SOMMERER, C.; MIGNONNEAU, L. (2008). Ubiquitous Gaming Interaction: Engaging Play Anywhere. In: SOMMERER, C.; JAIN, L.C.; MIGNONNEAU, L. (ed.) The Art and The Science of Interaction Design. Berlin Heidelberg: SpringerVerlag. p.115-130.

MATHIS, A. (2007). A sociedade na teoria dos sistemas de Niklas Luhmann. Disponível em: <http://www.infoamerica.org/documentos_pdf/luhmann_05.pdf>, em 02/ $\mathrm{abril} / 2007$.

MATUSSEK, P. (2008). Entrevista por Graziele Lautenschlaeger. Düsseldorf, Alemanha. 28jun2008. Arquivo de áudio, CD.

MEDEIROS, M. B.(org.) (2003). A arte pesquisa. Vol.1. Ensino e aprendizagem da arte. Linguagens visuais. Brasília, DF: Mestrado em artes, UnB.

. (2003). A arte pesquisa. Vol.2. História, teoria e crítica da arte. Brasília, DF: Mestrado em artes, UnB,.

. (2004). Arte em pesquisa: especificidades. Vol.1. Curadoria; História, teoria e crítica da arte; Questões do corpo e da cena; Restauro, conservação e materiais. Brasília, DF: Editora da Pós-graduação em Arte, UnB.

. (2004). Arte em pesquisa: especificidades. Vol.2 Ensino e aprendizagem da

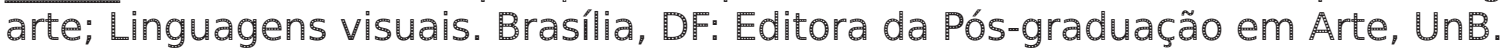

MEDIEN KUNST NETZ. (2009) Dan Graham: Present Continuous Past(s). Disponível em <http://www.medienkunstnetz.de/works/present-continuous-pasts/> Acesso em 10/Junho/2009.

- (2009) Overview of media art: perception. Disponível em <http://www. medienkunstnetz.de/themes/overview_of_media_art/perception> Acesso em 10/ jun/2009.

MESQUITA, S. N. (1994). O enredo. São Paulo: Ática. 
METZ, C. (1977). A respeito da impressão de realidade. A significação no cinema. São Paulo: Perspectiva.

MOELLER, H. G. (2006). Luhmann explained: from souls to systems. Peru, Illinois: Carus Publishing Company.

MORAN, T. (1991). The command language grammars: a representation for the user interface of interactive computer systems. International Journal of Man-Machine Studies, 15, pp.3-50.

MORIN, E (1972). Le paradigme perdu: la nature humaine. Paris: Éditions du Seui.

MORIYAMA, T. (2008). Next generation of japanese media art: current situation and students works. Palestra no Interface Culture Department. Linz, Áustria, 22abr.2008. Arquivo de áudio.

MURRAY, J.H. (2003). Hamlet no holodeck: o futuro da narrativa no ciberespaço. São Paulo: Itaú Cultural: Unesp.

NAIMARK, M. (2003) Truth, beauty, freedom, and money: technology-based art and the dynamics of sustainability. Report for Leonardo Journal. Disponível em <www. artslab.net>, em 28/abril/2008.

. (2008). Artists as toolmakers. Palestra no Interface Culture Department. Linz, Áustria, 23abr.2008. Arquivo de áudio.

NASCIMENTO, R. (2008). Entrevista por Graziele Lautenschlaeger. Linz, Áustria. 02 maio.2008. Arquivo de áudio, CD.

NEITSCH, S. (2008). Entrevista por Graziele Lautenschlaeger. Linz, Áustria. 08maio.2008. Arquivo de áudio, CD.

NICHOLS, B. (2003). The work of culture in the age of Cybernetic Systems. in WARDRIPFRUIN, N., MONFORT, N., The new media reader, Cambridge: MIT Press, 2003, p.625 $-641$.

OFFENHUBER, D. (2008). Entrevista por Graziele Lautenschlaeger. Linz, Áustria. 21 maio.2008. Arquivo de áudio, CD.

OGAWA, H. (2008). Entrevista por Graziele Lautenschlaeger. Linz, Áustria. 19maio.2008. Arquivo de áudio, CD.

PANGARO, P. Pask's Words and What We Want From Them: A Conversation Around Concepts from Conversation Theory. In: <http://www.pangaro.com/abstracts/antioch3-Pasks-words.html>

PARENTE, A. (1996). Imagem-máquina: a era das tecnologias do virtual. Rio de Janeiro: Ed. 34.

PASK, G., SCOTT, B., \& KALLIKOURDIS, D. (1973). A theory of conversations and individuals (Exemplified by the Learning Process of CASTE). International Journal of Man-Machine Studies, 5 (4), pp. 443-566.

PASK, G. (1970). A comment, a case history and a plan. In Cybernetic Serendipity, edited by J. Reichardt. Rapp and Carroll. Reprinted in Cybernetic Art and Ideas, edited by J. Reichardt. London: Studio Vista, 1971, p. 76-99. 
PAUL, C. (2008). Digital art / public art: governace and agency in the networked commons. In: SOMMERER, C.; JAIN, L.C.; MIGNONNEAU, L. (Ed.). The Art and the science of interaction design. Berlin Heidelberg: Springer-Verlag. p.163-185.

PETERSON, M. G., IVERSEN, O. S., KROGH, P. G., and LUDVIGSEN, M. (2004). Aesthetic interaction: a pragmatist's aesthetics of interactive systems. In Proceedings of the 5th Conference on Designing interactive Systems: Processes, Practices, Methods, and Techniques (Cambridge, MA, USA, August 01 - 04, 2004). DIS ‘04. ACM, New York, NY, 269-276.

PFAFFENBERGER, M. (2008). Entrevista por Graziele Lautenschlaeger. Linz, Áustria. 16 maio.2008. Arquivo de áudio, CD.

PFALLER, R. (org.) (2000). Interpassivität. Studien über delegiertes Genießen. Berlin Heidelberg New York.

PIAS, C. (2005). Analog, digital, and the cybernetic illusion. In Kybernetes. Vol.34, no. $3 / 4$, p. 543-550.

. (2004). Zombies of The Revolution. In: Zukuenfte des Computers. Zürich: Diaphanes. p. 47-66. Disponível em: <http://www.uni-due.de/ bj0063/texte/banff. pdf>. Acesso em 06ago.2009

PISON, M.J.M. de; PIQUERAS, D. (2008). Entrevista por Graziele Lautenschlaeger. Linz, Áustria. 10set.2008. Arquivo de áudio.

POPPER, F. (1975). Le déclin de l'objet - art action participation 1. Paris: Chêne.

. (1980). Art, action et participation: l'artiste et la criativité aujourd'hui. Paris: Edtións Klincksieck.

PRATSCHKE, A. (2002) Entre Mnemo e Locus: arquitetura de espaços virtuais, construção de espaços mentais. Tese de Doutorado em Ciências da Computação e Matemática Computacional - Instituto de Ciências Matemáticas e de Computação, Universidade de São Paulo, São Carlos.

. (2009). De objetos interativos a sistemas de arquitetura estendida: conversa com Usman Haque. V!RUS, São Carlos, n.2, 2 sem. Disponível em: <http://www. nomads.usp.br/virus/virus02/entrevista/pratschke.php>. Acesso em 22nov2009.

RABAGLIATI, R. (2006). AVI and the art system: interactive works at the Venice Biennale. In Proceedings of the Working Conference on Advanced Visual interfaces (Venezia, Italy, May 23 - 26, 2006). AVI ‘06. ACM, New York, NY, 3-6.

RANDOM, M. (2000). O Pensamento transdisciplinar e o real. São Paulo: TRIOM.

REIS, C.; LOPES, A. C. M. (1988). Dicionário de teoria da narrativa. São Paulo: Ática.

RENNERT, S.; WIESE, S. von (1996). Students of Paik, 1978-95: Christine Bernhard ... [ et al.]: Ausstellung vom 5 April bis 5. Mai 1996, Kunstmuseum Düsseldorf im Ehrenhof.

ROSE, J.N. (2003). How much cybernetics can you handle? In: Kybernetes. Vol.32 $\mathrm{n}-5 / 6$, p.728-737.

SANTOS, L. G. dos.(2003). Modernidade, Pós-modernidade e metamorfose da percepção. In Politizar as novas tecnologias: o impacto sócio-técnico da informação 
digital e genética. São Paulo: Editora 34.

SATOMI, M. (2008). Entrevista porGraziele Lautenschlaeger. Linz, Áustria. 01maio.2008. Arquivo de áudio.

SATOMI. M.; WILSON, H. P. (2009). Kobakant. Disponível em: <http://www.kobakant. at>. Acesso em 27jan2009.

SAUTER, J. (2008). Interfaces in public and semi-public spaces. In: SOMMERER, C.; JAIN, L.C.; MIGNONNEAU, L. (Ed.). The Art and the science of interaction design. Berlin Heidelberg: Springer-Verlag.

- (2008). Creating experience with New Media in Space. Palestra no Interface Culture Department. Linz, Áustria, 18abr.2008. Arquivo de áudio.

. (2009). <http://www.joachimsauter.com>. Acesso em 20Mar2009.

SCHARMER, O. (2006). Theory U: Leading from the Emerging Future: Presencing as a Social Technology of Freedom. Disponível em <www.ottoscharmer.com>. Acesso em Out2009.

SCHMIDT, B.U. (2008). Entrevista por Graziele Lautenschlaeger. 16Set2008. Por e-mail. Arquivo de texto.

SCOTT, B. (2004). Second-oreder cybernetics: an historical introduction. In: Kybernetes. Vol. 33, no 9/10, p. 1365-1378.

SOLDERITSCH, P. (2003). What is cybernetics? Disponível em: <http://www.grammarrodeo.net/portfolio/images/cybermap.jpg > Acesso em 06 ago.2009.

SOMMERER, C.; MIGNONNEAU, L. (2005). Desigining emotional, metaphoric, natural and intuitive interfaces for interactive art, edutainement and mobile communications. In: Computer \& Graphics 29, p.837-851. Disponível em <www.sciencedirect.com>. Acesso em out.2007.

. (2008). Entrevista por Graziele Lautenschlaeger. Linz, Áustria. 20maio.2008. Arquivo de áudio.

$\overline{15 \text { maio2008. }}$

(2009). <http://www.interface.ufg.ac.at/christa-laurent/>. Acesso em

SPERLING, D. (2008). Corpo + Arte = Arquitetura: proposições de Hélio Oiticica e Lygia Clark. In: Fios soltos: a arte de Hélio Oiticica. São Paulo: Perspectiva.

STRAUSS, A.; CORBIN, J. (1998). Grounded Theory in practice. Thousand Oaks: Sage Publicarion.

TURNER, F. (2006). From Counterculture to cyberculture: Stewart Brand, the whole Earth network, and the rise of digital utopianism. Chicago and London: The Univerity of Chicago Press.

VIRILIO, P. (1993). O espaço crítico. Tradução: Paulo Roberto Pires. Rio de Janeiro: Ed. 34.

VIS. (1999). Revista do Curso de Mestrado em Artes do Instituto de Artes da Universidade de Brasília. Brasília: vols.1 e 2, n.1 e 2. 
WEIBEL, P. (2005). Art and democracy. In: MAKING things public: atmospheres of democracy. Karlsruhe: ZKM; Cambridge: MIT Press.

. (2007). It is forbidden not to touch: some remarks on the (forgotten parts of the) history of interactivity and virtuality. In: GRAU, O. (Ed.). MediaArtHistories. Cambridge: MIT Press.

. (1996). The World as Interface: Toward the Construction of Context-Controlled Event-Worlds. In: DRUCKREY, T. (ed.) Electronic Culture: Technology and visual representation. New York: Apperture.

. (2008). Intelligent beings in an intelligent universe. In Intelligente Ambiente/ Intelligent Enviroment. p 06-26. s/d.

WEIXLER. A. (2008). Entrevista por Graziele Lautenschlaeger. Linz, 14 maio.2008. Arquivo de áudio.

WIENER, N. (1970). Cibernética: ou controle e comunicação no animal e na máquina. São Paulo: Polígono.

$\overline{\text { Cultrix. }}$

(1954). Cibernética e sociedade: O uso humano de seres humanos. São Paulo:

WU, C. (2006). Privatização da cultura: a intervenção corporativa nas artes desde os anos 80. São Paulo: Boitempo.

ZIELINSKI, S. (1999). Audiovisions: cinema and television as entr'acts in History. Amsterdam: Amterdam University Press

. (2006). Deep time of the media. Cambridge: MIT Press.

ZIELINSKI, S.; WAGNERMAIER, S.M.(Ed.). (2005). Variantology 1: On deep time relations of Arts, Sciences and Technologies. Köln: Verlag der Buchhandlung Walther König.

ZIELINSKI, S. LINK, D. (Ed). (2006) Variantology 2: On deep time relations of Arts, Sciences and Technologies. Köln: Verlag der Buchhandlung Walther König. 


\section{Capa e abertura de capítulos} llustração de Marcos Tadao Nagata.

\section{Media art: universo complexo das imagens sintéticas}

Figura 1.1: "Métamorphose" (Yaacov Agam, 1957, foto: Ron Erde) exemplo de arte óptico-cinética. Fonte: Popper (1975. p.24).

Figura 1.2: Esquema que sitetiza o argumento central do historiador de arte e tecnologia Frank Popper em “Art, action, participation: I'artiste et la créativité aujourd'hui". Fonte: Popper (1980, p. 332).

Figura 1.3: "Participation Visuelle" (Milan Dobes, 1970, Osaka, Japão). Exemplo de obra participativa no espaço público na Exposição Mundial de 1970. Fonte: Popper (1975, p.31).

Figura 1.4: "Estrutura Celular" (Lygia Clark, 1973, Paris). Fonte: Popper (1975, p.27).

Figura 1.5: "Life Writer": exemplo de uso de algoritmos genéticos e inteligência artificial em Media Art. Fonte: Sommerer; Mignonneau (2006, website).

Figura 1.6: Imagem de "World Skin" de Maurice Benayoun. Fonte: Benayoun (2007, website).

Figuras 1.7 e 1.8: Imagens da ópera The Jewel of Malta, espetáculo de ópera dirigido por André Werner com a participação do ART+COM. Fonte: ART+COM (2009, website).

Figura 1.9: (esq) Sketch da instalação "Duality". Figura 1.10: (dir) Pessoa interagindo com a instalação "Duality" (Tóquio, 2007). Fonte: ART+COM (2009, website).

Figura 1.11: Performer e público durante apresentação de Perfect Human durante o Ars Electronica 2008 (Linz, Áustria). Fonte: Satomi; Wilson (2008, website).

Figura 1.12: Sketch do funcionamento de Perfect Human, de Mika Satomi e Hannah-perner-Wilson. Fonte: Satomi; Wilson (2008, website).

Figura 1.13: Esquema de Dan Graham para vídeo instalação "Present Continuous Past(s)". Fonte: Medien Kuns Netz (1974, website). 
Figura 1.14: Maquete na qual se projetavam simultaneamente as quatro animações, as quais eram controladas pelos interatores através das cordas. Fonte: Lautenschlaeger (2008)

Figura 1.15: Interatores no FILE 2009. Foto: Mário Ladeira. Fonte: FILE (2009).

Figura 1.16: Esquema de fluxo de informação entre os sub-sistemas do funcionamento da instalação "Don't Give Up!". Modelagem 3D: Fábio Abreu Queiroz. Fonte: Lautenschlaeger (2009).

\section{Media Art: da meta-teoria à meta-experiência}

Figura 2.1: Mapa conceitual da Cibernética. Fonte: Solderitsch (2003, website).

Figura 2.2: Grafo que representa os links do núcleo da blogosfera. Fonte: Hurst (2006, website).

Figura 2.3: Visão hiperbólica da blogosfera. Fonte: Hurst (2007, website).

Figura 2.4: Semelhança de manifestações emergentes nos níveis micro e macro: cérebro e mapa de Hamburgo: imagens do livro "Emergência" de Steven Johnson. Fonte: Johnson (2003, p.7)

Figura 2.5: Musicolour Machine (1953, Meca Locarno, Streatham): obra de Gordon Pask e Robin McKinnon. Fonte: Pask (1968, p. 82).

Figura 2.5: Cartaz de divulgação da performance de Joseph Beuys e Nam June Paik em homenagem à George Maciunas na Academia de Arte de Düsseldorf. Figura 2.6: Nam June Paik e Joseph Beuys em performance. Foto: Ivo Dekovic. Fonte: Rennert; Wiese (1996, p. 72-3)

Figura 2.7: Participantes de "La Plissure du text" em várias cidades ao redor do mundo. De cima para baixo, da esquerda para a direita: T. Klinkowstein \& G. McKenna no La Mammelle (São Francisco, EUA); Zelko Wiener e colegas no Kulturservice Studio (Viena, Áustria); T. Klinkowstein \& R. Adrian no La Mammelle (São Francisco, EUA); Estudantes do Ontario College of Art na Music Gallery (Toronto, Canadá); Hank Bull no Western Front (Vancouver, Canadá); Estudantes do Ontario College of Art na Music Gallery (Toronto Canadá). Fonte: Ascott (1983, website)

Figura 2.8: Instalação interativa "Energie_Passagen" em frente à Casa da Literatura de Munique, Alemanha. Fonté: Fleischmann e Strauss (2004, website). 


\section{Meta-crítica: arquitetura e síntese do conhecimento}

Figura 3.1: Esquema de Otto Scharmer da "Theory U". Fonte: Schamer (2006, website).

Figura 3.2: Detalhamento esquemático da "Theory U". Fonte: Scharmer (2006, website).

Figura 3.3: Esquematização de Ranulph Glanville para demonstrara circularidade entre a caixa-preta e o observador (investigador). Fonte: Glanville (2009, p. 159).

Figura 3.4: Esquematização de Ranulph Glanville para demonstrar a circularidade entre a caixa-preta e o observador (investigador), com ênfase na descrição funcional delineada pelo observador/investigador e na abertura/ branqueamento das duas instâncias: caixa e observador. Fonte: Glanville (2009, p. 162).

Figura 3.5: Esquematização de Ranulph Glanville para demonstrar a circularidade entre a caixa-preta e o observador (investigador), com ênfase na possibilidade de um segundo (e infinitos) níveis de recursão do ato de se observar observador e caixa-preta. Fonte: Glanville (2009, p. 164).

Figura 3.6: A artista Dolo Piqueras descreve seu processo de criação. Nós, observando nosso próprio processo, do qual ela também faz parte. Fonte: Lautenschlaeger (2009).

Figura 3.7: Ferramentas amigáveis: processos unidirecionais. Figura 3.8: Jogadores em prática: processos recursivos. Fonte: Bijl (1995, p.12-13)

Figura 3.9: Imagem esquemática de uma estrutura de conhecimento. Fonte: Doignon e Falmagne (1999, p.04).

Figuras 3.10 e 3.11: Esquemas do livro de Aart Bijl sobre expressão, informação e conhecimento. Fonte: Bijl (1995, p. 12-3)

\section{Considerações finais}

Figura 4: Diagrama da plataforma Pachube. Fonte: Haque (2009, website). 


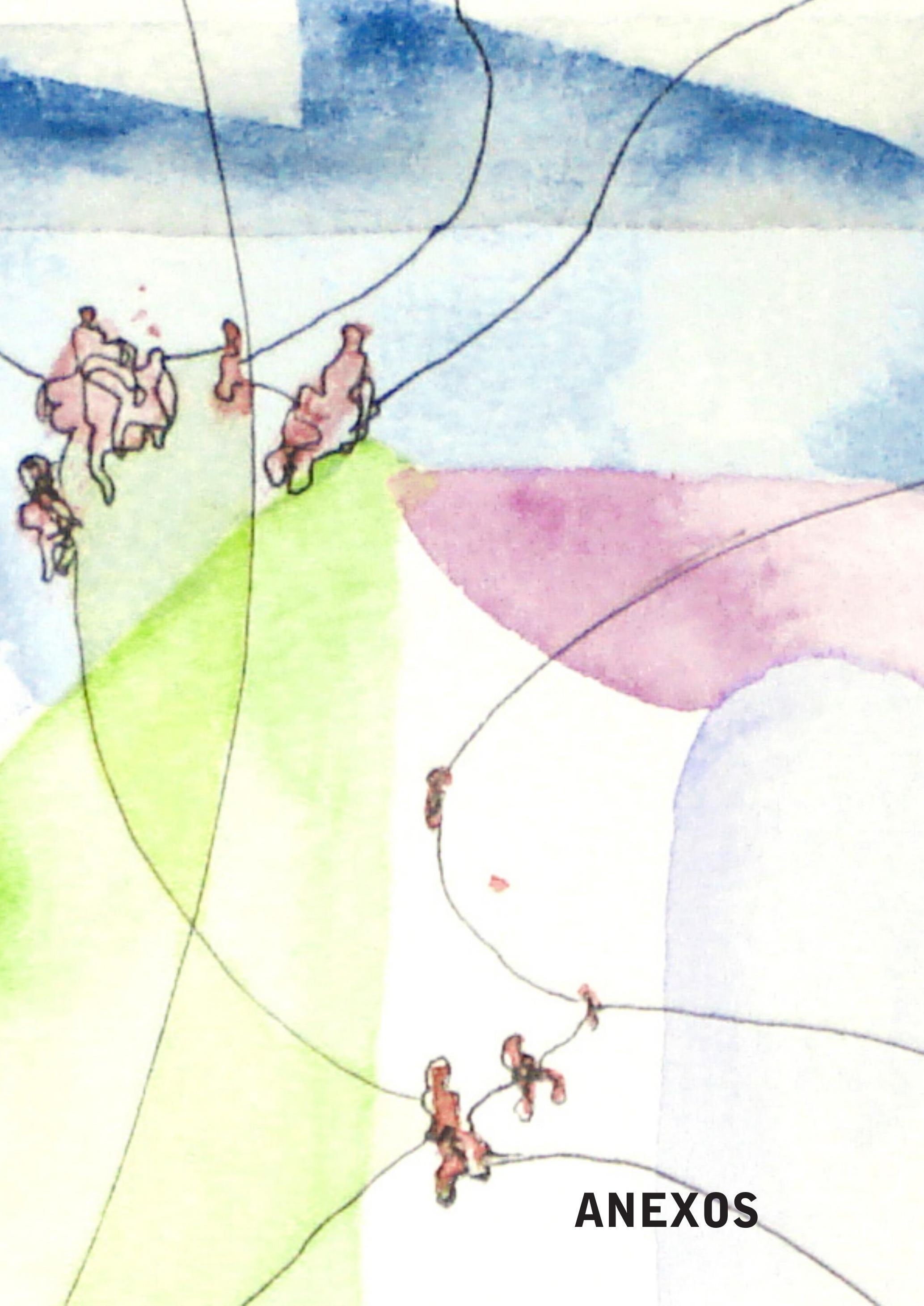


ANEXO A

CD: ENTREVISTAS 

